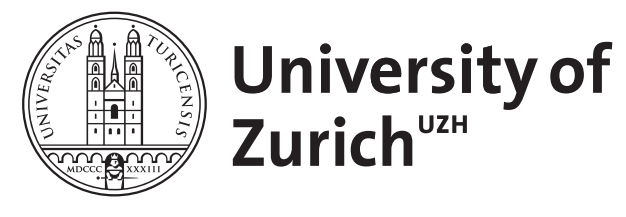

\title{
Ammonoid Intraspecific Variability
}

De Baets, Kenneth ; Bert, Didier ; Hoffmann, René ; Monnet, Claude ; Yacobucci, Margaret M ; Klug, Christian

\begin{abstract}
Because ammonoids have never been observed swimming, there is no alternative to seeking indirect indications of the locomotory abilities of ammonoids. This approach is based on actualistic comparisons with the closest relatives of ammonoids, the Coleoidea and the Nautilida, and on the geometrical and physical properties of the shell. Anatomical comparison yields information on the locomotor muscular systems and organs as well as possible modes of propulsion while the shape and physics of ammonoid shells provide information on buoyancy, shell orientation, drag, added mass, cost of transportation and thus on limits of acceleration and swimming speed. On these grounds, we conclude that ammonoid swimming is comparable to that of Recent nautilids and sepiids in terms of speed and energy consumption, although some ammonoids might have been slower swimmers than nautilids.
\end{abstract}

DOI: https://doi.org/10.1007/978-94-017-9630-9_9

Posted at the Zurich Open Repository and Archive, University of Zurich

ZORA URL: https://doi.org/10.5167/uzh-121836

Book Section

Accepted Version

Originally published at:

De Baets, Kenneth; Bert, Didier; Hoffmann, René; Monnet, Claude; Yacobucci, Margaret M; Klug, Christian (2015). Ammonoid Intraspecific Variability. In: Klug, C; Korn, D; De Baets, K; Kruta, I; Mapes, R H. Ammonoid Paleobiology: From anatomy to ecology. Dordrecht: Springer, 359-426.

DOI: https://doi.org/10.1007/978-94-017-9630-9_9 


\title{
Chapter 9 \\ Ammonoid Intraspecific Variability
}

\author{
Kenneth De Baets, Didier Bert, René Hoffmann, Claude Monnet, \\ Margaret M. Yacobucci and Christian Klug
}

\subsection{Introduction}

Individual organisms within extant species, including cephalopods (Boyle and Boletzky 1996), vary morphologically (size, shape, colour), physiologically, behaviorally, and demographically (Wagner 2000). This was no different for ammonoids,

\footnotetext{
K. De Baets $(\bowtie)$

GeoZentrum Nordbayern, Fachgruppe PaläoUmwelt, Universität Erlangen, Loewenichstr 28, 91054 Erlangen, Germany e-mail: kenneth.debaets@fau.de

D. Bert

UMR-CNRS 6118 Géosciences, Université de Rennes 1, campus Beaulieu, bâtiment 15, 35042 Rennes cedex, France e-mail: paleo-db@orange.fr

Laboratoire du Groupe de recherche en paléobiologie et biostratigraphie des ammonites (GPA), Bois-Mésanges, quartier St-Joseph, 04170 La Mure-Argens, France

R. Hoffmann

Department of Earth Sciences, Institute of Geology, Mineralogy, and Geophysics, Ruhr-Universität Bochum, 44801 Bochum, Germany

e-mail: Rene.Hoffmann@rub.de

C. Monnet

UMR CNRS 8198 Evo-Eco-Paleo, Université de Lille, UFR Sciences de la Terre (SN5), Avenue Paul Langevin, 59655 Villeneuve d'Ascq, France

e-mail: claude.monnet@univ-lille1.fr

M. M. Yacobucci

Department of Geology, Bowling Green State University, 190 Overman Hall, Bowling Green, Ohio 43403-0218, USA

e-mail:mmyacob@bgsu.edu

C. Klug

Paläontologisches Institut und Museum, University of Zurich, Karl Schmid-Strasse 6, 8006 Zurich, Switzerland e-mail: chklug@pim.uzh.ch

C. Klug et al. (eds.), Ammonoid Paleobiology: From Anatomy to Ecology,

Topics in Geobiology 43, DOI 10.1007/978-94-017-9630-9_9
} 
which are well-known for intraspecific variation in conch shape, ornamentation, ontogeny, size, as well as the morphology of the suture line (e.g., Westermann 1966; Kennedy and Cobban 1976; Tintant 1980; Dagys and Weitschat 1993a, b; Kakabadze 2004; Bersac and Bert 2012a, b; De Baets et al. 2013a; Bert 2013). Some specimens of a species were large, others were smaller at maturity; some specimens of a species were more involutely coiled and less densely ribbed, while others were more loosely coiled and more coarsely ribbed. Intraspecific variation also occurs in the shape or position of the suture line (e.g., Yacobucci and Manship 2011) or in dextral or sinistral coiling of the conch (e.g., Matsunaga et al. 2008) as seen in extant gastropods. Ammonoids might also have differed intraspecifically in colour patterns (e.g., Mapes and Sneck 1987; Bardhan et al. 1993; see also Mapes and Larson 2015), buccal mass (Davis et al. 1996; Keupp 2000; Keupp and Mitta 2013; compare Kruta et al. 2015) or other characteristics which are rarely or not preserved at all such as soft-tissues (Klug et al. 2012) or other peculiar structures (Landman et al. 2012). We will herein focus on intraspecific variation in shell shape, ornamentation and size, as well as spacing and shape of the septa (suture lines), for which more data are available.

Mollusks in general and ammonoids in particular are known to display a sometimes profound morphological intraspecific variability of their shell. Although this phenomenon is of greatest importance, it has rarely been investigated and quantified in large samples adequately. Studies of intraspecific variability in ammonoids have focused on coiled Mesozoic ammonoids, while Mesozoic heteromorphs (Kakabadze 2004; Bert 2013) and Paleozoic ammonoids (Kaplan 1999; Korn and Klug 2007; De Baets et al. 2013a) have been comparatively less investigated. Not properly taking intraspecific variability into account mostly leads to taxonomic oversplitting (or lumping) and thus not only significantly biases taxonomy and diversity counts, but also biostratigraphic, evolutionary and paleobiogeographic studies (e.g., Kennedy and Cobban 1976; Tintant 1980; Dzik 1985, 1990a; Hughes and Labandeira 1995; Nardin et al. 2005; Korn and Klug 2007; De Baets et al. 2013a, b; Bert 2013; compare Sect. 9.5), particularly if the authors have very different principles when defining species between certain timeframes or regions. Geographic variation might also lead to specimens of a single biological species being erroneously assigned to different morphospecies based on differences in shell morphology, ornamentation and/or size (e.g., Kennedy and Cobban 1976; Courville and Thierry 1993).

More importantly, heritable (genetic) variation is believed to be the raw material for evolution and natural selection (e.g., essays by Charles Darwin and Arthur Wallace compiled in De Beer 1958; Mayr 1963; Hallgrimmson and Hall 2005; Hunt 2007). This makes the mode and range of intraspecific differences interesting with respect to their genetic heritability. They are of ecological and evolutionary interest in terms of the environmental influences that shape them, both non-genetically in the present and genetically over an evolutionary time scale (Wagner 2000). It is, however, hard to separate heritable phenotypic variation from variation resulting from a plastic response to the environment (Urdy et al. 2010a), especially in extinct groups. For instance, a large part of the intraspecific variability in shelled mollusks could be caused by differences in growth rates (Urdy et al. 2010a) and development 
(Courville and Crônier 2003, 2005). This could also explain certain recurrent patterns in intraspecific variation in the shells of ammonoids and other mollusks with coiled shells (e.g., Dommergues et al. 1989; Urdy et al. 2010b, 2013; Urdy 2015). Extant cephalopods can comprise a high intraspecific variability, particularly in their variable size-at-age, which can be related to intrinsic as well as extrinsic (environmental) factors (Boyle and Boletzky 1996; compare De Baets et al. 2015a; Keupp and Hoffmann 2015 for pathologies affecting growth).

The main goal of this chapter is to review the main types of intraspecific variation reported in shell shape, ornamentation, suture line and adult size within and between ammonoid populations and how they might have been shaped by development and the environment. Additionally, we briefly review the main methods that can be used to quantitatively study intraspecific variation. For this purpose, we focus on studies that have specifically dealt with intraspecific variation as well as more general studies that have discussed particular patterns of intraspecific variation, including case studies from the literature and our own studies ranging from Devonian to Cretaceous ammonoids. Before doing this, we will set up the main terminology used to study intraspecific variation and possible sources of variation between and within fossil populations, including those not related to intraspecific variation, which might bias the results of studies on intraspecific variation in fossil samples.

\subsection{Definitions}

Here, we define some commonly used terms related to variation within and between populations of the same species, which are ubiquitous in extant species. This is generally referred to as intraspecific or phenotypic variation, sometimes as "Individual variability" (Darwin 1859) or occasionally somewhat confusingly as phenotypic "polymorphism" (e.g., Fusco and Minelli 2010; see below for a stricter definition of polymorphism). Phenotypic variation results from both genetic and environmental factors. Traditionally, evolution is assumed to consist of (genetic) changes in populations over time (Tintant 1980), making it the central goal of biology to understand the complex interactions that mediate the translation from genotype (the genetic make-up or precise genetic constitution of an organism: Lawrence 2000) to phenotype (the visible or otherwise measurable physical and biochemical characteristics of an organism, resulting from the interaction of the genotype and the environment: Lawrence 2000). Phenotypic variability is closely related to phenotypic variation and is defined as the potential or tendency of an organism (e.g., a species) to vary (Wagner and Altenberg 1996). This means that variation can be documented as a series of static observations within a sample - each observation representing a single instance of the many phenotypic expressions resulting from interactions of genetic and environmental factors-while variability can be seen as a more abstract view of the range or distribution of potential variation, which comprises all possible outcomes, realized or not (Willmore et al. 2007). Note, that analyzing variation in fossil 
samples or "populations" is even more complex than in extant populations, because differences between specimens can relate to other factors than intraspecific variation (Tintant 1980; discussed in Sect. 9.3).

Intraspecific variation in certain characters of a species can be continuous (e.g., following a unimodal Gaussian distribution) and/or discontinuous such as polymorphism. Polymorphism is traditionally defined as the occurrence together in the same habitat of two or more distinct forms of a species in such proportions that the rarest of them cannot be maintained merely by recurrent mutation (Ford 1955, 1965). According to the definition of Ford $(1940,1945,1955,1965)$, this excludes geographic and seasonal forms as well as continuous variation falling within a curve of normal distribution. Mayr (1963) introduced the term polyphenism to distinguish environmentally induced phenotypic variation ("the occurrence of several phenotypes in a population, the differences between which are not the result of genetic differences"; Mayr 1963, p. 670) from genetically controlled phenotypic variation or genetic polymorphism. Although Mayr (1963) specifically included both continuous and discontinuous variation, the term polyphenism is often restricted to refer to two or more distinct phenotypes produced by the same genotype (e.g., Simpson et al. 2011), which would make polyphenism a particular case of phenotypic plasticity (West-Eberhard 2003). The term polyphenism has occasionally also been used for ammonoids (e.g., Reyment 2003, 2004), sometimes interchangeably with polymorphism (Parent 1998; Parent et al. 2008). The switch between forms is believed to be environmental in polyphenism (e.g., Fusco and Minelli 2010), while the switch is believed to be "almost always" genetic in (genetic) polymorphism (Ford 1966; this should not be confused with the use of the same terminology by molecular biologists for certain point mutations in the genotype, which do not necessarily correlate with recognizable phenotypic effects: Fusco and Minelli 2010). In ammonoids, polymorphism has been traditionally used to refer to two or more discrete coexisting forms within the same fossil population (Tintant 1980; Davis et al. 1996 and references therein; Klug et al. 2015), although others have used it more generally to include also continuous variation (e.g., Beznosov and Mitta 1995). We suggest using the term polymorphism only to refer to discontinuous variation in ammonoids to avoid confusion and to be in line with its most common use. We will therefore use polymorphism here to refer to discontinuous intraspecies variation without interpreting a potential genetic or environmental switch between these forms or variants, although in some cases (like sexual dimorphism) a genetic mechanism is obvious (at least in cephalopods).

Polymorphism or polyphenism should not be confused with polytypism. The latter term refers to the presence of geographically or ecologically isolated populations within a species, which differ morphologically (Tintant 1980). It is not uncommon that the mode and range of intraspecific variation varies between different samples or populations depending on the environment (ecophenotypic variation) or region (geographic variation). Phenotypic variation that is attributable to environmental variation is referred to as ecophenotypic variation (Foote and Miller 2007). The tendency of a single genotype to produce different phenotypes depending on environment gradients is known as phenotypic plasticity (Lawrence 2000). WestEberhard (1989) defined it differently as the ability of a single genotype to produce 
more than one alternative form of morphology, physiological state, and/or behavior in response to environmental conditions; both definitions are hard to verify in the fossil record. All these types of variation might also have occurred in ammonoids, but their study is hampered by the difference between biological populations and fossil populations, which are affected by various taphonomic and collection biases, as well as various other factors, discussed in more detail in the Sect. 9.3.

\subsection{Sources of Variation within and between Fossil Populations}

Measurements of individuals of the same species within and between fossil populations (separated in time and/or space) can show variations that can not only be associated with intraspecific or phenotypic variation (which includes ecophenotypic variation and geographic variation), but also with ontogenetic variation, phylogenetic variation, taphonomic biases (including post-mortem transport and distortion, time-averaging and differences in preservation), taxonomic uncertainty, and simple measurement errors, particularly in the case of small size (compare Tintant 1980; Stephen and Stanton 2002; Foote and Miller 2007; Bert 2013; De Baets et al. 2012, 2013a, 2015b).

Individual organisms of the same species can vary in their phenotype, resulting from the interaction of its genotype and the environment. More precisely, the features of individual organisms result from developmental processes, which are influenced by environmental conditions as well as its genetic make-up. Intraspecific variation refers to the variation within a species at a comparable ontogenetic stage, age and/or size (Foote and Miller 2007). Changes in ontogeny and differences between sexes might also contribute to the variation of the overall population. Ontogenetic variation is therefore factored out by studying specimens only at comparable ontogenetic stages or sizes (De Baets et al. 2013a). Traditionally, only a single set of measurements from "mature" specimens are used (so-called cross-sectional data by opposition to longitudinal data based on measurements of the same individuals at several developmental stages: compare Klingenberg 1996; Foote and Miller 2007), which are recognized by adult modifications. Studying the entire ontogeny, in the form of ontogenetic trajectories or changes in these measured characters through development might be more meaningful, particularly in taxa where the earlier ontogeny is more variable than the later ontogeny (e.g., De Baets et al. 2013a). This means that for each ontogenetic stage, a statistically significant number of measurements should ideally be available ( $>30$ : compare Bert 2013; De Baets et al. 2013a; Sect. 9.9).

Sexual variation is sometimes factored out too by studying only specimens of the same sex (Foote and Miller 2007) or antidimorphs (Sect. 9.4.2). This might not always be advisable, e.g., when subjectively sorting out specimens based on size and subsequently testing for significant differences between them: compare Tintant (1980). Populations of a species can also vary in features between different localities or regions (interpopulational variation), although it might be hard to 
attribute this purely to geographic variation in the fossil population. Phylogenetic variation related to changes through time might also play a role, although it is hard to separate such variation from geographic variation without proper time constraints (Kennedy and Cobban 1976; Tintant 1980). Furthermore, fossil ammonoid populations might include specimens from different paleoenvironments, water depths and seasons depending on the environment as well as the degree of transport and timeaveraging; these are important factors, which should be considered when studying ecophenotypic and geographic variation.

These complications are related to the fact that fossil populations have passed through various taphonomic filters such as post-mortem transport, post-mortem distortion and time-averaging (Foote and Miller 2007). To avoid time-averaging (Fig. 9.1) as much as possible, populations are usually studied from a restricted stratigraphic interval, such as a single layer, horizon or preferentially a single concretion or nodule (Reeside and Cobban 1960; Dzik 1990a; Dagys and Weitschat 1993a, b; Fig. 9.2, 9.23); nevertheless, opinions vary in this respect and sometimes some compromises (pooling of samples resulting in "analytical time averaging": compare Fürsich and Aberhan 1990) have to be made to have a sufficiently large sample for statistical analysis (Dzik 1990a; Bert 2013). Any estimate of population variability is potentially falsifiable by further studies on material collected from a narrower stratigraphic interval or different localities (Dzik 1990a). Note that even for fossils deriving from a single bed, there is little control over the time range of the specimens contained within this bed (Foote and Miller 2007). Ammonoid assemblages like all other shell assemblages (Olóriz 2000; Wani 2001) —even those contained within a single nodule-have typically undergone various amounts of taphonomic filters and time-averaging (Kidwell 2002), which, in modern shelf environments, might range between 100 and 10,000 years (Powell and Davies 1990; Kidwell and Bosence 1991; Flessa and Kowalewski 1994; Kidwell 1998; Wani 2001; Kowalewski 2009). Short-term time-averaging (on the order of up to several thousand years) prevails in nearshore shallow environments, whilst long-term timeaveraging (in the order of $10^{4}$ to $10^{5}$ years) becomes more important towards lower shelf and deep sea environments (Fürsich and Aberhan 1990). However, some evidence suggests that variances within fossil samples are not necessarily dominated by time-averaging (Tintant 1980; Hunt 2004a, b). Well-preserved specimens, particularly those with in situ buccal masses, as well as the lack of preferred orientation, size distribution and other biostratinomic data have been used to support lack of (strong) condensation or (long) transport (compare Wani and Gupta 2015). Not only animals that lived during different times, but also organisms coming from various depths (i.e., living in different parts of the water column or at different seafloor depths) might be mixed within these assemblages, particularly in pelagic shell assemblages, which can also be related to post-mortem floating or transport of their shells. Taphonomic studies can be important to disentangle different post-mortem histories of shells within the same fossil sample and can also give information on the faunal succession (Fernández-López 1995, 2000; Wani and Gupta 2015). However, it is not generally true that less well-preserved shells are older-their preservation mainly depends on how much time they spent on the sea bottom (or afloat) and the degree to which they were subjected to diagenesis during burial as well as 


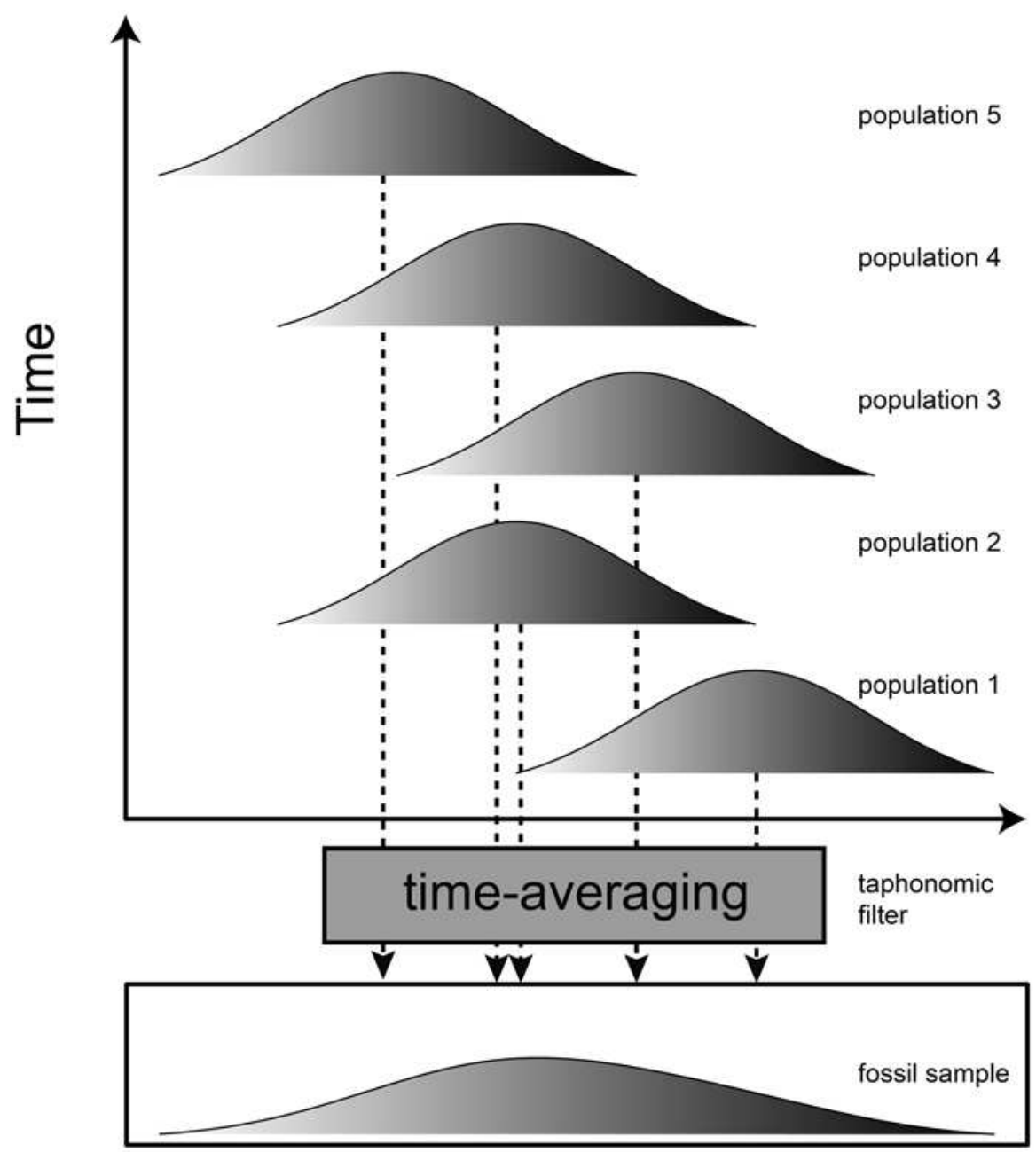

\section{Phenotypic Trait}

Fig. 9.1 Schematic illustration of the effect of fossil mixing and/or analytical lumping on the observed phenotypic variance (modified from Hunt 2004a; with permission from the author). The variance of the time-averaged (fossil) sample is greater than the variance of the individual populations representing five stages in the evolutionary sequence of an evolving lineage, which shows an almost steady decrease in a phenotypic trait over time. The density distribution of the fossil sample is also flatter (more platykurtic) than is ever observed in a single time slice

in which paleoenvironments they resided (e.g., Flessa et al. 1993). According to Tintant (1980), long-term time-averaging or condensation as well as reworking can even be seen in some quantitative analyses, which might reveal a distribution flatter than a normal distribution (e.g., platykurtic distribution due to considerable timeaveraging: Fig. 9.1) or a polymodal distribution (due to reworking). 


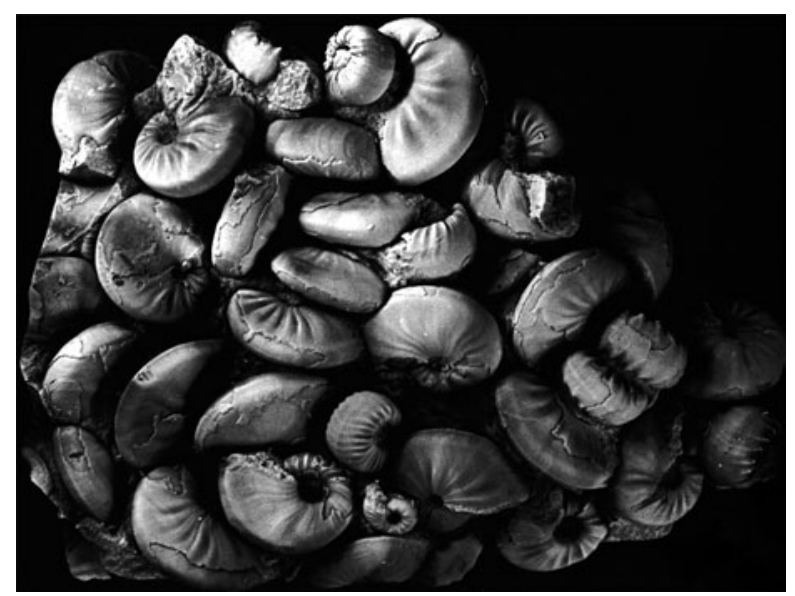

Fig. 9.2 The extensive range of intraspecific variation observed within Czekanowskites rieberi within a single carbonatic concretion from the Lower Anisian of Mount Tuaray-Khayata in Arctic Siberia (modified from Dagys and Weitschat 1993b; with permission from the author)

Fossil ammonoids can be deformed and distorted by abrasion, compaction, dissolution and tectonic deformation, these processes represent an important obstacle to research on their variability. Depending on the degree of deformation, specimens can be retrodeformed to their original shape in many cases, but not necessarily their original dimensions (Blake 1878; Tan 1973; Rocha and Dias 2005; De Baets et al. 2013b; Yamaji and Maeda 2013). Studies of intraspecific variability have therefore preferentially used largely undeformed, three-dimensionally preserved specimens. Early diagenetic concretions are ideal to study intraspecific variation from this perspective (Reeside and Cobban 1960; Dzik 1990a; Dagys and Weitschat 1993a, 1993b; Fig. 9.2). The appearance of ornamentation and measurements of the same parameters might differ between differentially preserved specimens (internal moulds vs. shell preservation). Furthermore, fossils can be extremely compacted in some lithologies, particularly in shales, which might lead to the increase of the whorl height and diameter as well as a decrease of whorl thickness and umbilical width (e.g., Morard 2004; De Baets et al. 2013b; Wani and Gupta 2015). These effects could even lead to the erection of endemic "species" restricted to certain lithologies (see De Baets et al. 2013b for such a case in the early Emsian ammonoid Ivoites). In such cases, it probably makes sense to correct for taphonomic processes in the most conservative way to avoid artificially inflating diversity (De Baets et al. 2013b). Specimens from the same sample (with similar preservation) are generally deformed in the same way, so that the introduced systematic error might be less significant (Dzik 1985). More importantly, certain parameters such as rib count per half-whorl and diameter at mid-whorl height can be affected by differential compaction in different lithologies and thus, the material should be examined for such deformation prior to the beginning of data collection (De Baets et al. 2013b). Differential compaction might contribute to trends in increased whorl compression 
from shallower environments with coarser sedimentation to deeper environments with finer sedimentation (Wilmsen and Mosavinia 2011; Bert 2013).

Additionally, variation might be related to false assignment of specimens to the same species, which depends on the objectivity and opinion of the scientists involved. Authors explicitly or implicitly include a range of intraspecific variation in their definitions of taxa, which might artificially inflate (oversplitting, often the case in strict typological approaches: compare Sect. 9.5) or deflate diversity (lumping). Oversplitting might occur when only a little well-preserved material is available with a precise age assignment and/or locality/region, while lumping occurs particularly when considering specimens from a wide range of stratigraphic ages and localities/regions to belong to the same taxon. If the entire range of variation occurs at the same age and place, this might be a good indicator that they belong to one and the same species (Tintant 1980). The effects of lumping or oversplitting might be partially counteracted by randomly distributed new discoveries, revalidations and/or invalidations of species over time (compare Nardin et al. 2005). The variable interpretation of the range of intraspecific variation also affects the disparity (morphological richness) recognized within a species (e.g., Courville and Crônier 2005). A study by Nardin et al. (2005) on Jurassic ammonoids demonstrated that extreme forms are often identified and named before intermediate forms (particularly for ornamentation, while shell geometry is often underused to define species). Such problems can only be resolved by quantitatively studying as many characters as possible in large samples, which can make it easier to recognize species (by finding significant differences in these characters) and their range of intraspecific variation. Each measurement or count carries with it a possibility of error (Van Valen 2005). Variation in measurements within a single sample might also be related to these measurements errors, which are usually estimated by repeated and independent measurements of the same specimens, or a randomly chosen appropriate subset of them (e.g., Bailey and Byrnes 1990; Van Valen 2005). In some cases, errors might be small enough to be neglected (Van Valen 2005), while in other cases, when the magnitude of the variable of interest is close to the measuring precision, they can blur (De Baets et al. 2013a) or even erase the original signal.

\subsection{Types of Intraspecific Variation in Ammonoids}

\subsubsection{Continuous Variation}

Most authors agree that continuous variation is recognized by a series of interconnected morphologies in a restricted interval in time and space (Reeside and Cobban 1960; Kennedy and Cobban 1976; Silberling and Nichols 1982; Dzik 1985, 1990a). Typically, all intermediate forms should be present and more common than extreme morphologies leading to a unimodal distribution. The best evidence for continuous intraspecific variation is often believed to be a unimodal, normal (Gaussian) distribution (Tintant 1980; Silberling and Nichols 1982; Dagys and Weitschat 1993b; 
Weitschat 2008; Monnet et al. 2010). However, even in such cases, it cannot be entirely ruled out that such distributions contain various sympatric species (inhabiting the same or overlapping geographic areas), which are inseparable based on their hard part anatomy alone (Tintant 1980; Dzik 1990a) and therefore cannot be picked up in the fossil record. For example, Dommergues et al. (2006) showed that in the extant gastropod Trivia the differences of the hard part anatomy (excluding the colour patterns) between such closely related species is insufficient to infer the existence of two separate sympatric species, masking the true underlying biodiversity. On the other hand, when the distribution is not normal or unimodal, it does not necessarily mean that the specimens belong to different species either (Tintant 1980). Such a distribution could originate from environmental influences, taphonomic biases, sampling biases or the fact that the distribution is not of a Gaussian kind (for example in the case of discrete variation within a species such as dimorphism or non-sexual polymorphism: Klug et al. 2015).

Continuous variation has typically been analyzed from the perspectives of covariation among traits and development. Studies have focused particularly on strongly ornamented, coiled Mesozoic ammonoids, including taxa deriving from:

- the Triassic (e.g., Silberling 1956; Silberling and Nichols 1982; Dagys and Weitschat 1993a, b; Checa et al. 1996; Dagys et al. 1999; Dagys 2001; Monnet and Bucher 2005; Weitschat 2008; Monnet et al. 2010),

- the Jurassic (e.g., Tintant 1963, 1980; Westermann 1966; Sturani 1971; Howarth 1973; Dzik 1985, 1990a; Westermann and Callomon 1988; Mitta 1990; Bhaumik et al. 1993; Beznosov and Mitta 1995; Guex et al. 2003; Courville and Crônier 2005; Morard and Guex 2003; Bert 2004, 2009; Morard 2004, 2006; Zatoń 2008; Chandler and Callomon 2009; Baudouin et al. 2011, 2012; Bersac and Bert 2012a, b),

- and the Cretaceous (e.g., Haas 1946; Reeside and Cobban 1960; Kennedy and Hancock 1970; Kennedy and Cobban 1976; Kennedy and Wright 1985; Meister 1989; Kassab and Hamama 1991; Reyment and Kennedy 1991, 1998; Courville and Thierry 1993; Tanabe 1993; Aguirre-Urreta 1998; Courville and Crônier 2005; Yacobucci 2004b; Wiese and Schulze 2005; Ploch 2007; Wilmsen and Mosavinia 2011; Bersac and Bert 2012a, b; Knauss and Yacobucci 2014).

These studies have demonstrated strong variations in shell shape (whorl cross section, coiling) and ornamentation (strength, spacing). Many authors discussed a marked covariation between shell shape and strength of ornamentation and more rarely also with shape, frilling and spacing of the suture line (compare Sect. 9.3). One peculiar case of such covariation is often coined as Buckman's rules of covariation (Westermann 1966; for further details, see Monnet et al. 2015a). Such covariations have also been reported above the species level between different taxa, both in the Paleozoic (Swan and Saunders 1987; Kaplan 1999) and Mesozoic (e.g., Yacobucci 2004a; Brayard and Escarguel 2013). It is, however, not obvious that this rule can be extended beyond intraspecific variation. Yacobucci (2004a), for example, measured the variance of ornamentation and whorl shape within a number of ammonite genera and found that they do not correlate. Hammer and Bucher (2005) 
attributed this to varying ratios of proportionality of Buckman's law across species, which could potentially weaken the interspecific correlation between ornamentation and whorl shape (e.g., some species have stronger lateral ribs relative to shell width than others). Such exceptions might form a problem for studies that interpret such continuous Buckman's type intraspecific variation within taxa based on limited material (compare Monnet et al. 2008) or without properly quantitatively analyzing this intraspecific variation (e.g., Howarth 1973, 1978). One should remain cautious in such cases as discussed by Tintant $(1976,1980)$. Howarth (1973) studied Dactylioceras from four distinct levels in the Lower Toarcian of Yorkshire and interpreted a large continuous variation (compare Morard 2004, 2006) between forms (classically attributed to Orthodactylites) with more evolute inner whorls, a compressed whorl section and weak ornamentation (thin ribs, often bifurcated and non-tuberculated) to forms (traditionally attributed to Kedonoceras and Nodicoeloceras) with more involute inner whorls, a depressed whorl section and strong ornamentation (thick, more widely spaced ribs with tubercles) in earlier ontogeny. Tintant $(1976,1980)$ investigated a French sample of Dactylioceras from the first level and reported both a marked dimorphism and possible non-sexual polymorphism in the form of the coexistence of forms with compressed inner whorls without lateral tubercles (morphotype "Orthodactylites clevelandicum") and forms with a depressed whorl section and lateral tubercles (morphotype "Nodicoeloceras acanthum"). Interestingly, Tintant $(1976,1980)$ reported that the whorl width index (whorl width/ whorl height) is strongly bimodal below $50 \mathrm{~mm}$, but in later growth stages, the forms become progressively more similar, resulting in remarkably similar final body chambers. All intermediates are available between these forms, but the extreme forms appear to be most abundant and the intermediate forms the least abundant. Tintant (1980) suggested that this might indicate polymorphism or even the presence of two species with similar evolutionary trends and convergence in their adult body chambers (compare Monnet et al. 2015b). However, Tintant's $(1976,1980)$ analyses were preliminary and more detailed analyses of the evolutionary history and intraspecific variability of these groups are necessary to corroborate such hypotheses. Furthermore, the influence of potential environmental differences (e.g., Wilmsen and Mosavinia 2011) as well as taphonomic and sampling biases also needs to be considered (compare Sect. 9.3).

Continuous variation has been studied less in larger samples of Paleozoic ammonoids (e.g., Kaplan 1999; Korn and Vöhringer 2004; Ebbighausen and Korn 2007; Korn and Klug 2007; De Baets et al. 2013a). Korn and Klug (2007) reported a large variation in several conch parameters in Manticoceras throughout the ontogeny of a single specimen (ontogenetic variation) as well as at the same size between different specimens (e.g., intraspecific variation). This variation in Manticoceras had already been noticed by Clarke (1899) but it was largely ignored by subsequent authors, resulting in a plethora of species and genera with (small) differences in conch shape, but comparable suture lines and ornamentation, thus making the genus a kind of waste basket taxon (Korn and Klug 2007). In some cases, intraspecific variation consistent with Buckman's first law of covariation might also be present in Paleozoic ammonoids (e.g., Kaplan 1999; De Baets et al. 2013a). 
In Mesozoic taxa showing this covariation, a remarkable range of intraspecific variation in ornamentation still remains in forms with the same shell morphology and size (Morard and Guex 2003). Wiese and Schulze (2005) reported a marked variation in the umbilical width of Neolobites vibrayeanus from a funnel-like deepening to a well-developed umbilicus reaching $18 \%$ of the diameter, which did not show a covariation with either the ribbing strength or the degree of inflation. The range and mode of intraspecific variation might also depend on shell morphology, particularly the degree of coiling (De Baets et al. 2013a). Such hypotheses are best tested by comparing closely related and/or contemporary species with different shell morphologies. Dagys (2001, p. 546) stated that the range and degree of covariation decreased towards taxa with very involute subcadiconic shells on the one hand and increased with most evolute platyconic shells on the other hand. This observation illustrates that the mode and range of interspecific correlation between ornamentation and whorl shape might depend on shell morphology (cf. Ubukata et al. 2008). Tanabe and Shigeta (1987) studied the intraspecific variation of whorl thickness (S) and distance of the venter from the coiling axis (D) at the same growth stage in cross-sections of Cretaceous ammonoids. This variation was the highest in heavily ornamented (e.g., Acanthocerataceae) and heteromorph forms (e.g. Scaphitaceae), intermediate in finely ribbed platycones (Lytocerataceae) and the smallest in weakly ribbed, heavily streamlined involute-compressed morphotypes (Hypophylloceras, Placenticeras and most Desmocerataceae) in the small samples of Cretaceous ammonoids they investigated. Further studies on larger samples are necessary to further corroborate these results and rule out the potential interference of ornamentation on measurements of these parameters in cross sections (which could introduce apparent variation which is not actually there).

Heteromorph ammonoids might be particularly useful for testing such hypotheses. Many authors have acknowledged high intraspecific variability in heteromorph ammonoids (e.g., Egojan 1969; Rawson 1975a, b; Dietl 1978; Ropolo 1995; Delanoy 1997; Wiedmann and Dieni 1968; Wiedmann 1969; Kennedy 1972; reviewed in Kakabadze 2004; De Baets et al. 2013a, b; Bert 2013), maybe even more than in normally coiled planispiral ammonoids (Dietl 1978; Kakabadze 2004). However, besides studies on Scaphites (reviewed in Landman et al. 2010; Knauss and Yacobucci 2014), which only uncoils at the end of ontogeny, intraspecific variation has been only rarely studied in numerically large samples and/or quantitatively in heteromorphs with openly coiled and/or trochospirally coiled whorls (Aguirre-Urreta and Riccardi 1988; Dietl 1978; Ropolo 1995; Delanoy 1997; De Baets et al. 2013a; Bert 2013). This lack of research might be due to their fragmentary preservation (De Baets et al. 2013a) and difficulties in quantifying some of their shell characters using traditional morphometrics and classical "Raupian" parameters (Tsujino et al. 2003; Parent et al. 2009, 2011; Bookstein and Ward 2013).

Dimorphism is also known from several Mesozoic (Jurassic and Cretaceous) heteromorphs (see reviews in Delanoy et al. 1995; Davis et al. 1996). In some cases, however, continuous variation in shell and/or ornamentation is present, which could 

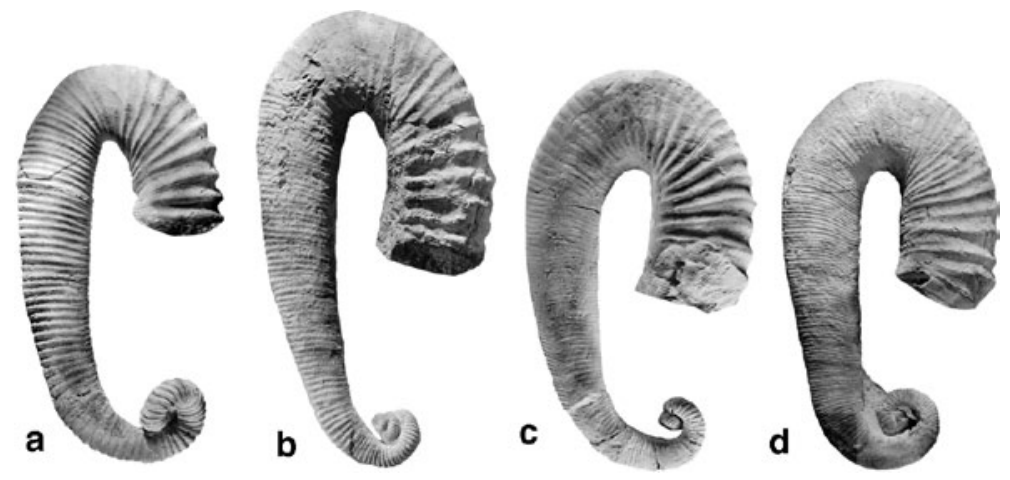

Fig. 9.3 Range of intraspecific variation observed in the coiling and ornamentation of the Late Barremian heteromorph Heteroceras emerici (after Delanoy 1997; modified from Bert 2013)

potentially be confused with dimorphism in studies using small samples and/or lacking quantitative analyses (compare Ropolo 1995). Dietl (1978) reported intraspecific variation in planispiral to trochospiral coiling in the Jurassic genus Spiroceras without a clear correlation with strength of ornamentation and any ornamental or thickness influence of the whorl section. Delanoy (1997) reported continuous variation from the Cretaceous ammonoid Heteroceras emerici (Fig. 9.3) between a pole with heterocone coiling (imericum morphology: large turricone and no planispiral part of the shell before the shaft) and a pole with colchicone coiling (leenhardtii morphology: small turricone preceding a substantial planispiral portion before the shaft) interconnected by all intermediates (e.g., the tardieui and emerici morphologies). Similar variation has also been reported from Imerites (Bert et al. 2011).

De Baets et al. (2013a) reported that in the Early Devonian, loosely coiled Erbenoceras, the more coarsely ornamented specimens are also those with the thickest whorl section. This fits with the redefinition by Hammer and Bucher (2005) of Buckman's First Law of Covariation (Monnet et al. 2015a). However, the coiling shows an opposite covariation with ornamentation to that seen in coiled Mesozoic morphs and some heteromorph forms, as the more tightly coiled conchs are the most heavily ornamented forms instead of the most loosely coiled forms. The correlation of ribbing strength with coiling might be indirect because covariation between whorl shape and coiling geometry are also known from weakly ornamented to smooth or unornamented coiled taxa such as from some Lytoceratina and Phylloceratina (Joly 2003; Morard 2004). Joly (2003) reported that "less-thick shells have an elliptic section and the thickest shells have an oval section". Ubukata et al. (2008) also attributed part of the covariation with constructional linkage between whorl shape and coiling geometry. The rule specifically refers to strength of ornamentation, but usually the spacing of ribs is used as this is more readily available and less affected by preservation and preparation (e.g., Yacobucci 2004a; De Baets et al. 2013a; Monnet et al. 2015a). Bert (2013) reported that ornament strength did not correlate perfectly with rib density in Gassendiceras, which he attributed to the large distance between ribs in this taxon, thus leaving more room for strength varia- 


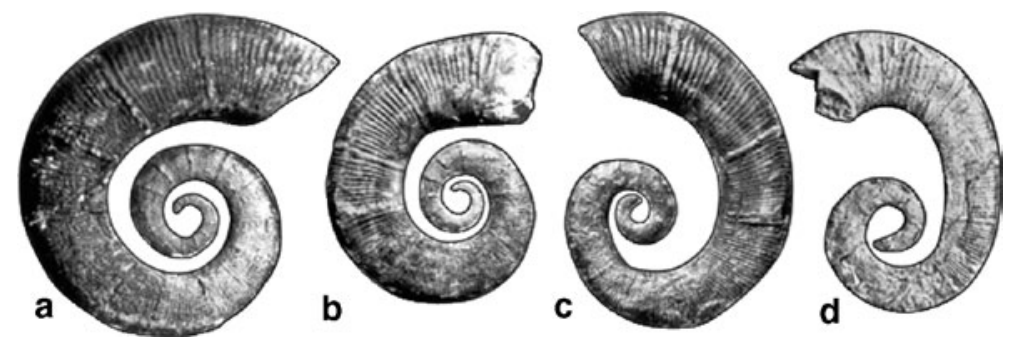

Fig. 9.4 Range of intraspecific variation observed in the coiling of the Hauterivian heteromorph Crioceratites. (after Ropolo 1995; modified from Bert 2013)

tion without changing their spacing (compare Bert 2013). The lack of correlation of ornamentation with coiling in some species of Crioceratites (Ropolo 1995; Bert 2013; Fig. 9.4) could potentially also be related to differences in growth between Crioceratites, characterized by a "discontinuous" mode of growth as documented in their megastriae as well as constrictions on the one hand, and other ammonoids with a "differential" mode of growth on the other hand (e.g., Bucher 1997, p. 98). Things are further complicated by the fact that such a correlation might be present in more primitive species like C. loryi (Bert 2013), although this still needs to be quantitatively investigated.

Continuous intraspecific variation usually ranges between two extreme morphologies, but some authors have reported more complex patterns of intraspecific variation between three or more morphological poles in shell shape and/or ornamentation (Rieber 1973; Vermeulen 2002; Bert 2009, 2013: review in the latter; Courville 2011). Bert (2013) quantitatively studied the intraspecific variation in Cretaceous Gassendiceras alpinum and reported continuous intraspecific variation between three poles: (1) robust specimens characterized by a depressed whorl section and strong ornamentation, (2) more traditional gracile or slender specimens characterized by a finer ornamentation and compressed whorl section and (3) specimens characterized by a depressed whorl section and non-robust ornamentation (Fig. 9.5a). All poles are connected by intermediates. Interestingly, Bert (2009) reported an inversed pattern in Tornquistes (Jurassic; Fig. 9.5c), which is characterized by morphological poles with a thin whorl section and respectively thin and robust ornamentation, and a morphological pole with a thick whorl section and weak ornamentation. The whorl section can be differently affected by compaction, which could blur the relationship between the whorl section thickness and the strength of ornamentation, but it cannot explain all aspects of tripolar patterns of intraspecific variation in these taxa (Bert 2013). Similar patterns were reported from the Pulchellidae (Vermeulen 2002; Fig. 9.5b) and the Kosmoceratidae (Courville 2011).

Rieber (1973) reported continuous variation between four extreme poles ranging from unornamented or smooth forms to forms with ribs and/or tubercles in Repossia acutenodosa (Triassic) from a single bed (Fig. 9.6), although the relationship between shell shape and ornamentation was not discussed and no quantitative analysis was performed. 


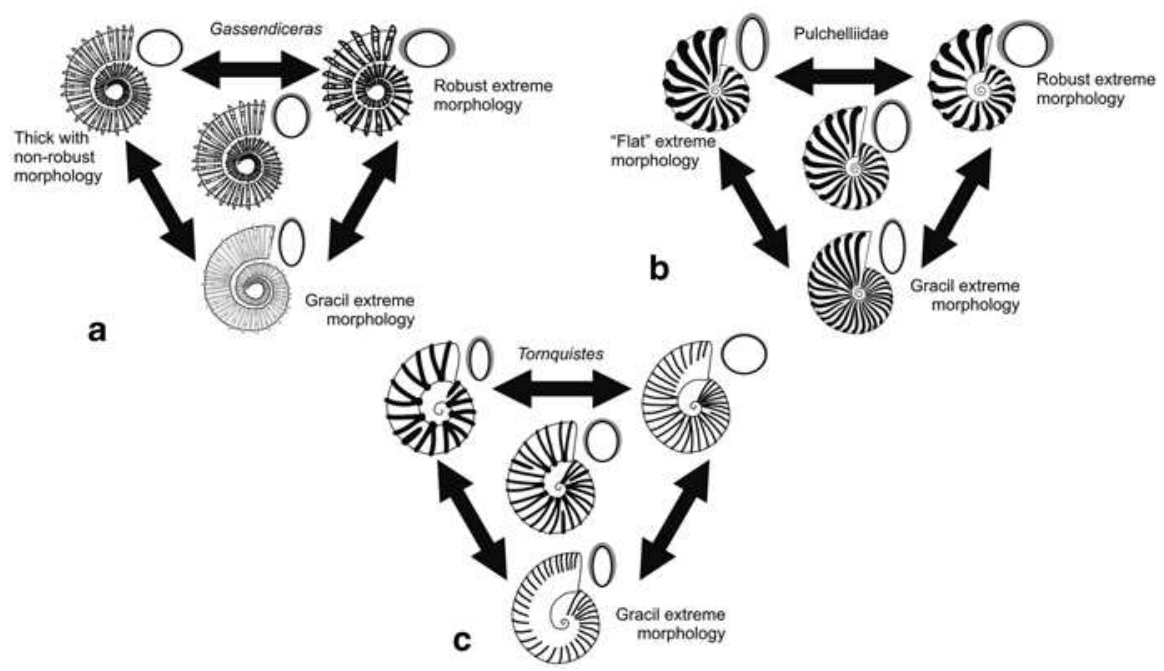

Fig. 9.5 Tripolar intraspecific variation observed in Gassendiceras (Late Barremian), Pulchellidae (Barremian) and Tornquistes (Middle Oxfordian) (modified from Bert 2013)

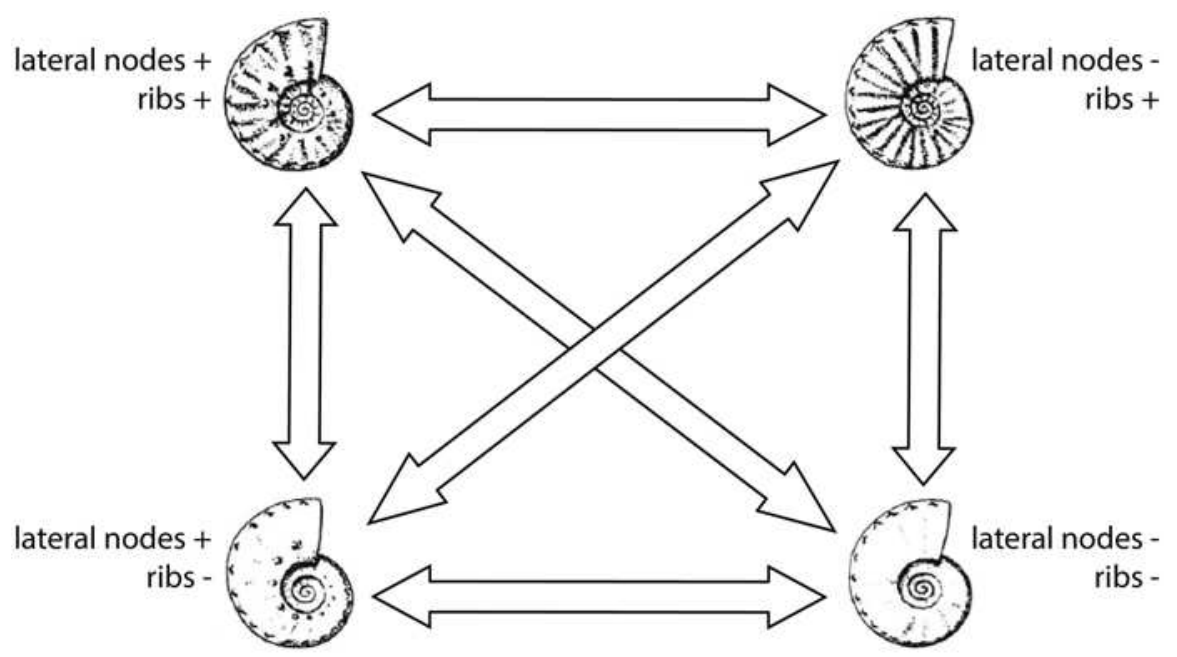

Fig. 9.6 Intraspecific variation reported in Repossia acutenodosa (Anisian) between four extreme poles of ornamentation (modified from Rieber 1973)

Other authors have used relative shifts in development (i.e., heterochronies of the development), which have often been used in the context of ontogeny/phylogeny relationships, to describe intraspecific morphological variations (Schmidt 1926; Dommergues et al. 1986; Meister 1989; Mitta 1990; Beznosov and Mitta 1995; Courville and Crônier 2003; Bersac and Bert 2012a, b; Bert 2013; also dimorphism: Neige et al. 1997a; Fig. 7, 8a). In some cases, specimens might even omit entire 

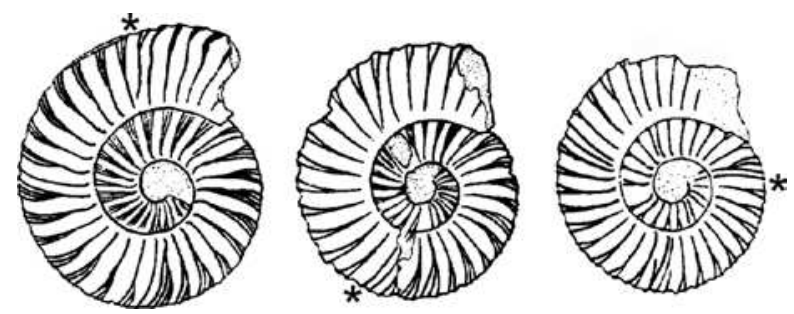

Fig. 9.7 Range of intraspecific variation in timing of ontogenetic development observed in Virgatites pusillus (Tithonian; modified from Mitta 1990; with permission from the author); from left to right: a bradymorphic, a normomorphic and a tachymorphic individual

ontogenetic stages during development (e.g., in Placenticeras: compare Klinger and Kennedy 1989; Bert 2013). According to Mitta (1990), Michalsky (1890) was one of the first to notice this phenomenon of different rates of shell morphogenesis in individuals of the same species within Volgian ammonoids. Schmidt (1926) interpreted a similar phenomenon in Carboniferous ammonoids and introduced the terms bradymorphic (in terms of heterochronies: paedomorphic) and tachymorphic (in terms of heterchronies: peramorphic) to refer to the extreme end members of these series within a species, which possess characteristics of earlier whorls later in development or which possess characteristics of later stages of development earlier, respectively (Beznosov and Mitta 1995). Beznosov and Mitta (1995) defined these terms (see Fig. 9.7) in the following way: "In the tachymorphic forms, the shell or separate elements of it (the sculpture, crosssectional shape, width of the umbilicus, angle of inclination of the umbilical wall) even at small diameters have already taken on an appearance usually typical of a later stage of development. In the bradymorphic individuals the shell for a long time retains features typical of a younger individual. Brady-and tachymorphy are most clearly manifested in the duration of one or another stage of development of the sculpture, the extreme representatives of the variation series (typical bradymorphs and typical tachymorphs) often differing so strongly that, if the collections do not contain "normal" (or normomorphic) forms, they may be described as different species, although they occur at the same stratigraphic level." Such intraspecific differences in development have been reported in particular from large samples of Jurassic (Dommergues et al. 1986; Mitta 1990; Baudouin et al. 2011, 2012; Fig. 9.7) and Cretaceous ammonoids (Meister 1989; Courville and Crônier 2003; Bersac and Bert 2012a, b; Bert 2013; Fig. 9.8a). It was interpreted to be a dominant factor in the variability of Nigericeras gadeni (Courville and Crônier 2003) and Vascoceras (Meister 1989) of the Cenomanian of Nigeria, while in other taxa like the Middle Liassic Aegoceras capricornus, it was only a residual factor (Dommergues et al. 1986, Fig. 6). In some taxa such as Deshayesitidae (Bersac and Bert 2012a, b; Fig. 9.8a), Gassendiceras (Bert 2013), as well as Streblites and Taramelliceras (Baudouin et al. 2011), this type of variation was also reported to be combined with variation following Buckman's first law of covariation between whorl section and ornamentation. 


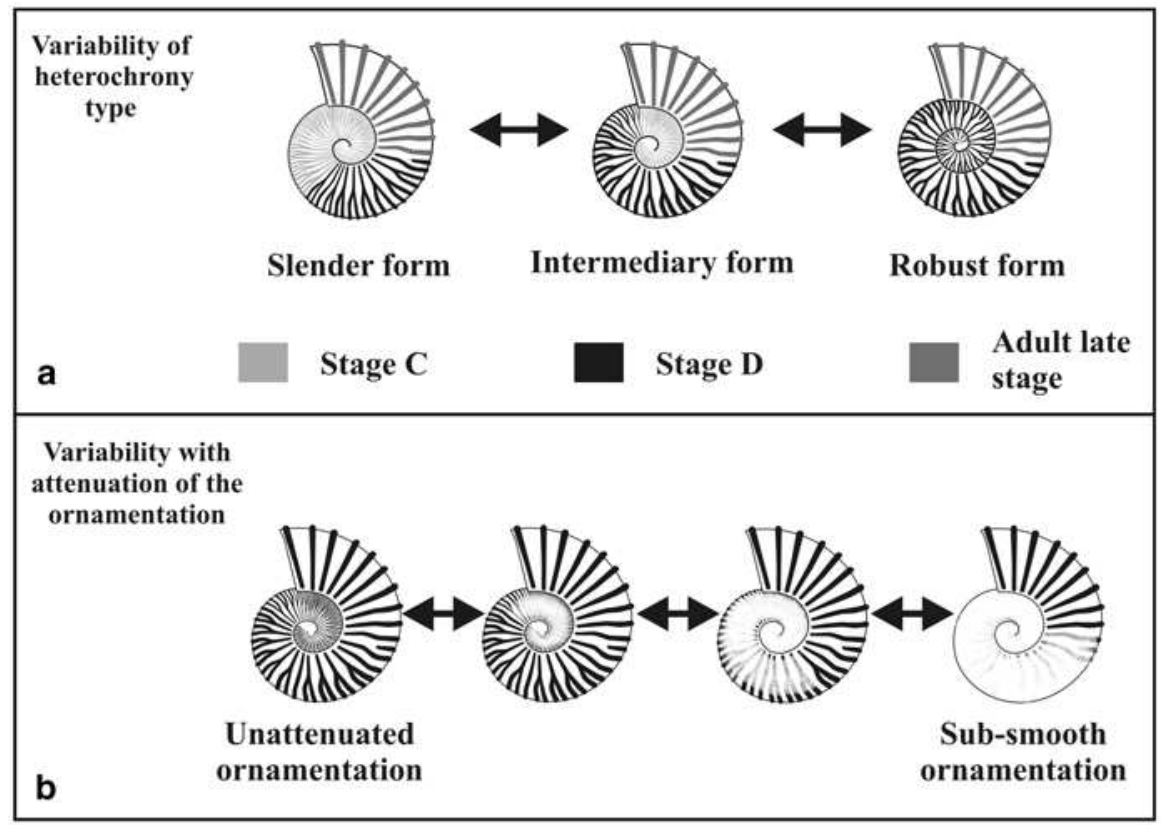

Fig. 9.8 Types of intraspecific variation differing from the first Buckman's Law of covariation observed within the Deshayesitidae (Early Cretaceous; after Bersac and Bert 2012a, b; modified from Bert 2013)

Not all types of intraspecific variation relate to covariation between shell shape and ornamentation or relative shifts in development. Bersac and Bert (2012a, b; Fig. 9.8b) reported intraspecific variation in the relative timing of ornamentation attenuation in the Aptian Deshayesitidae (another classical example of oversplitting), which was independent of Buckman's type covariation between shell shape and ornamentation as well as a heterochronic shift in development (which were also present), as they cut across the entire range of morphologies associated with these intraspecific patterns. This type of variation might also play a role in other taxa (Bert 2013) such as the Douvilleiceratidae, particularly the genus Douvilleiceras (Courville and Lebrun 2010), or in the genus Vascoceras (Courville 1993). In the former genus, disappearance of ornamentation may occur from medium diameters irrespective of the type of morphology (ranging from slender forms with weak ornamentation to the hyper-ornamented robust forms). The two approaches to studying intraspecific variation might also be unifiable as several authors have reported links between differences in rates and shifts in development on the one hand and shell morphology on the other hand. Some authors have interpreted the presence of gracile "peramorphic" forms (thin whorl section, almost smooth) to robust "paedomorphic" forms (thick whorl section, strong ornament) linked by all intermediates in the same species (Courville and Crônier 2003; Baudouin et al. 2011, 2012; Bersac and Bert 2012; Bert 2013). In other taxa such as Streblites weinlandi, the 
relationship might however be reversed, with the most slender specimens being the most paedomorphic (Baudouin et al. 2011, 2012). Others have tried to explain the covariation of the suture line and shell shape from a developmental perspective (Hammer and Bucher 2006).

\subsubsection{Discontinuous Variation}

The most accepted pattern of discontinuous intraspecific variation in ammonoids is dimorphism (Makowski 1962; Callomon 1963; Tintant 1963; Westermann 1964), which is often interpreted to represent the two sexes (Lehmann 1981; Delanoy et al. 1995; Davis et al. 1996). Such dimorphism is supported by having overlapping stratigraphic and geographic distributions as well as distinct ratios within a population. This dimorphism is thought to result typically in a bimodal signal in adult size and/or morphology in later ontogeny (e.g., Palframan 1966, 1967; Ploch 2003; Zatoń 2008; Fig. 9.9). However, the presence of two morphs within an ammonoid species
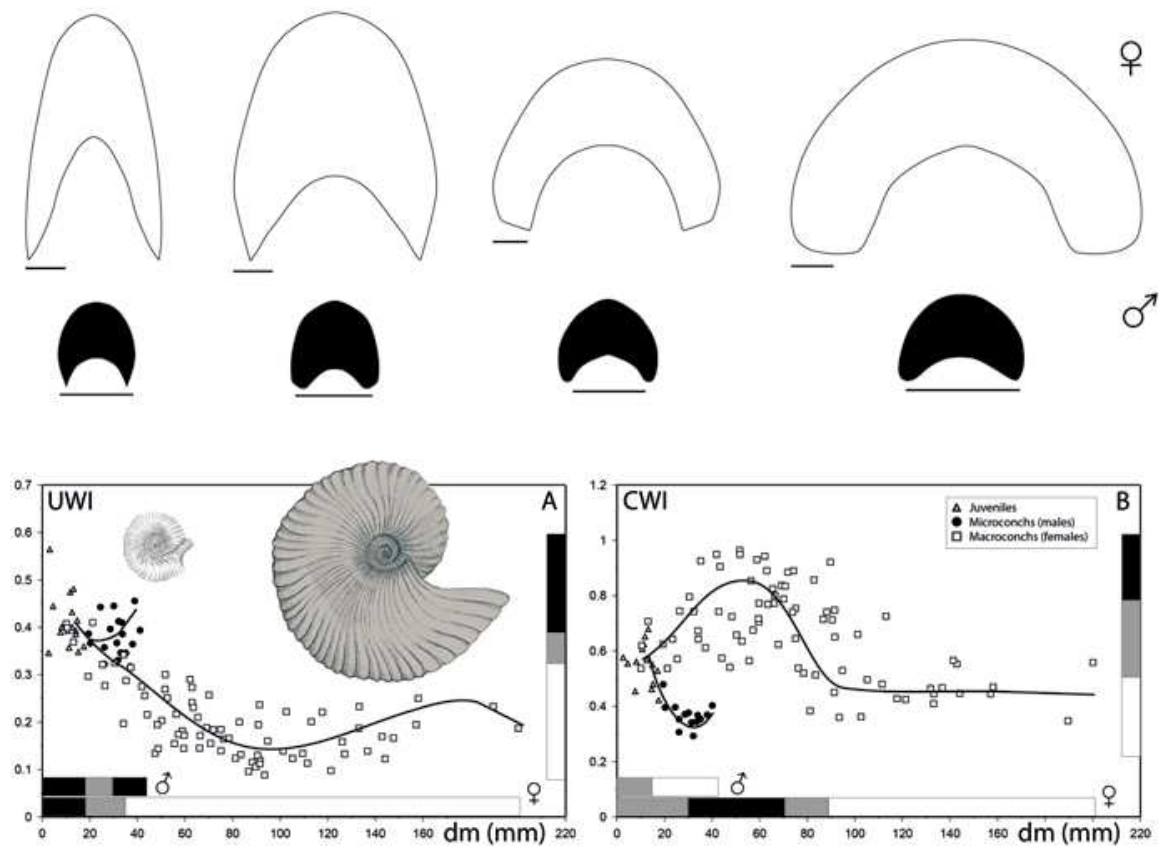

Fig. 9.9 Continuous intraspecific variation combined with marked dimorphism in later ontogeny within Morrisiceras morrisi (Bathonian; modified from Zaton 2008; with permission of the author). Note the similar early ontogeny of both antidimorphs, but marked bimodal differences in adult morphology and size between the microconch and macroconch. Both the microconch and macroconch show a continuous variation in whorl cross section at similar sizes 
does not necessarily reflect sexual dimorphism (e.g., Reyment 1988), particularly when no clear differences can be found in later ontogeny or pre-adult forms are more dissimilar than adult forms (e.g., Tintant 1980; Davis et al. 1996). Additionally, interpretations of dimorphism within taxa might differ between authors (e.g., Brochwicz-Lewinski and Rózak 1976). Dimorphism is discussed in further detail in Klug et al. 2015. In some cases, more than two discrete forms in adult size within a species have been reported (e.g., Ivanov 1971a, 1975; Matyja 1986, 1994; compare (Sect. 9.7)), which might be related to differences in rate and length of development. Furthermore, sometimes multiple morphs might be present in one or both of the sexes (Sonny Walton 2014, personal communication). Several authors studying homogenous and synchronous populations of Jurassic ammonoids have noted the presence of morphologically similar groups only distinguishable with the presence or absence of certain characters (Tintant 1963, 1976; Tintant 1980; Contini et al. 1984; Atrops and Mélendez 1993; Meléndez and Fontana 1993; Davis et al. 1996; Bardhan et al. 2010), particularly in ornamentation (presence of one or two rows of lateral tubercles, trifurcation vs. single and biplicate ribs, presence or absence of parabolic ribs, etc.). Interestingly, this variation can occur independently of sexual dimorphism as it affects both macroconchs and microconchs of these taxa in the same way (Tintant 1963, 1976, 1980; Charpy and Thierry 1976). A classic example is Kosmoceras (Tintant 1963, 1976, 1980), which possesses "a clear sexual dimorphism with a microconch bearing mature modifications" (Davis et al. 1996, p. 501). For a long time, two genera or subgenera were distinguished only differing in the presence of one ("Zugokosmoceras") or two rows of lateral tubercles (Kosmoceras) in contemporaneous populations. If no intermediate morphologies are found, it would be more conservative to interpret these as separate taxa, but some authors have argued that such forms should be interpreted as cases of intraspecific polymorphism, when these two groups display parallel, evolutionary changes or trends (Tintant 1980; Atrops and Meléndez 1993) in other characters. Such assertions of evolutionary trends (Monnet et al. 2015b) in these characters still have to hold to novel statistical methods which can analytically support the presence of evolutionary trends (Hunt 2006; Monnet et al. 2011a) and test how parallel evolutionary (or ontogenetic) trajectories really are (Adams and Collyer 2009, Collyer and Adams 2013; applied to ammonoids in Monnet et al. 2011a; De Baets et al. 2013a). Tintant $(1963,1976)$ has supported his claims not only by the study of numerous populations, but also with the discovery of a pathological macroconch displaying a "Zugokosmoceras" pattern on one side and a "Kosmoceras" pattern on the opposite side. Reports of polymorphism are not restricted to ornamentation, but might also occur in shell morphology, particularly shell thickness (Fig. 9.10).

Several authors have reported the presence of discontinuous variation in whorl section thickness in some Jurassic ammonoid taxa (Charpy and Thierry 1976; Marchand 1976; Tintant 1980; Contini et al. 1984; Fig. 9.10). In some cases, the two forms are more similar in morphology at the end of the ontogeny, as discussed by Tintant $(1976,1980)$. Nevertheless, such discontinuous distributions might also be related to differences in paleoenvironments, taphonomic and collection biases (temporal and spatial mixing), and sample sizes (Tintant 1980; Wilmsen and Mo- 

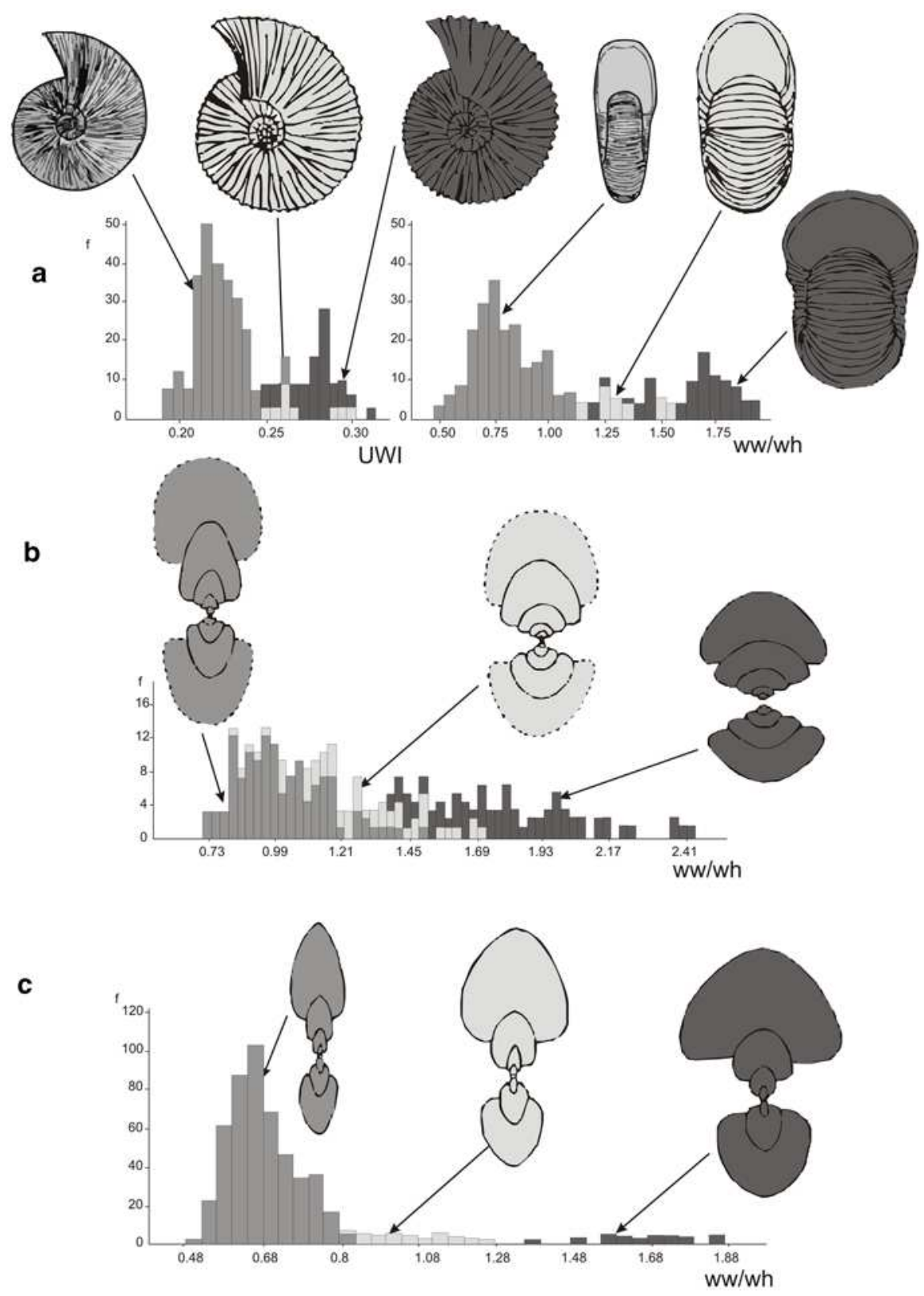

Fig. 9.10 Possible cases of discontinuous intraspecific variation interpreted as non-polymorphism in Jurassic ammonoids (redrawn from Contini et al. 1984): A sample of microconch specimens of Macrocephalites (Upper Callovian, Gracilis Zone, Michalskii sub-zone of Arino, Spain) interpreted to be three different morphs of a single species, which were previously interpreted to belong to three different subgenera and species: Dolikephalites gracilis (compressed shell with narrow umbilicus and fine ribbing), Kamptokephalites herveyi (round section with intermediate umbilicus 
savinia 2011; De Baets et al. 2013a). As evidenced by Wilmsen and Mosavinia (2011), variation in a trait might be discontinuous even in taxa at some localities/ paleoenvironments showing otherwise continuous variation. This might depend on paleoenvironmental conditions, further stressing the need to study intra- and interpopulation variation in ammonoids to further elaborate these patterns (Tintant 1980; Callomon 1988; Sect. 9.8).

Polymorphism in ornamentation and/or whorl thickness has also been reported from Cretaceous ammonoids (e.g., Hirano 1978, 1979; Reyment 1988; Kassab and Hamama 1991; Gangopadhyay and Bardhan 2007), although it is not always clear whether it reflects sexual dimorphism or could even be part of a more continuous variation. In Upper Cretaceous ammonoids, dimorphism is recognized in most families, especially based on differences in size and only occasionally on mature modifications, and intraspecific variation is important though of unequal proportion between some groups (Kennedy and Wright 1985). Various authors have described the presence of polymorphism (two or more variants) recognizable in whorl thickness, coiling and/or ornamentation in Carboniferous ammonoids (McCaleb et al. 1964; McCaleb and Furnish 1964; Furnish and Knapp 1966; McCaleb 1968), which is reminiscent of continuous variation in Mesozoic coiled ammonoids, particularly the covariation of ornamentation with coiling and whorl shape. Davis et al. (1996) raised doubts about these Carboniferous accounts because of the presence of intermediates between these morphs, particularly as in some cases the forms seem to differ more in juvenile stages than in the adult stage (Davis et al. 1996; but they might still represent cases of non-sexual polymorphism according to Tintant 1980). Tintant (1980) has also discussed the possibility of non-sexual polymorphism in whorl width index and ornamentation in Dactylioceras (Jurassic), which varies less in early ontogeny than in late ontogeny. At least in some cases (e.g., Arkanites), as evidenced by Stephen et al. (2002), these Paleozoic morphs might be indistinguishable in juvenile stages and then later on during ontogeny show a bimodal distribution in shell parameters, which might indicate sexual dimorphism (compare Davis et al. 1996; Sarti 1999; Fig. 9.9). Nevertheless, large differences in adult size and mature modifications of the aperture used to recognize sexual dimorphism in Jurassic ammonoids seem to be absent in Paleozoic forms (e.g., Davis et al. 1996; compare Makowski 1962, 1991). The different nature of this dimorphism does not necessarily speak against it being of a sexual nature, as in some cases, there is little differences in size (or morphology) between sexes in extant cephalopods (e.g., for

\footnotetext{
and strong ribbing) and Pleurocephalites folliformis (depressed shell with large umbilicus and very strong ribbing); B sample with distinct morphologies of Pachyceras lalandeanum (Upper Callovian, Lamberti Zone of Villers-sur-Mer, Calvados, France; ordered from compressed to depressed section) interpreted as intraspecific polymorphism, which were previously considered to belong to three distinct species and two different genera (P. lalandeanum, $P$. crassum, Pachyerymnoceras jarryi); C sample with distinct morphologies of Quenstedtoceras (Upper Callovian Lamberti zone, Lamberti subzone of Magny-les-Villers, Champs Mollous, Côte-dÓr, France), which were previously described as three different (sub)genera and species: $Q$. (Lamberticeras) lamberti with a compressed section, Quenstedtoceras (Eboraciceras) ordinarium with an intermediate section and Quenstedtoceras (Sutherlandiceras) carinatum with a depressed section (modified from Contini et al. 1984)
} 
Nautilus: Ward 1987; for squids: Zuev 1971). Other possible reports of polymorphism in Paleozoic ammonoids or intraspecific variation (Kant 1973a, b; 1975; Davis et al. 1996, p. 490-491) are dubious because of the low sample size and the fact that specimens described as one species are now known to belong to multiple taxa (Dieter Korn 2013, personal communication).

It is not uncommon to see discontinuous shape and ornament within a species, including mollusks, alongside more continuously expressed variations in size, shape or ornament (Reyment and Kennedy 1991). Continuous variation in shell shape, ornamentation and/or suture line can be combined with dimorphism and/ or non-sexual polymorphism within the same species (e.g., Jurassic: Tintant 1963; Westermann 1966; Zatoń 2008; Chandler and Callomon 2009; Cretaceous: Ploch 2003; Landman et al. 2010). Sexual dimorphism might also be associated with nonsexual polymorphism as discussed by Charpy and Thierry (1976), Tintant (1963, 1976, 1980) and reviewed by Contini et al. (1984) for several Middle Jurassic ammonoids, although it is unclear if all these cases represent discontinuous variation. In other cases, no evidence is found for the presence of dimorphism (or polymorphism) associated with continuous variation (Reeside and Cobban 1960; Dagys and Weitschat 1993b; Monnet et al. 2010; De Baets et al. 2013a; but compare Sarti 1999), which might speak for the absence of polymorphism (at least in shell morphology) in these ammonoids showing more continuous variation.

In the Triassic, low sample size has often led to confusion of dimorphism with continuous variation (e.g., Dzik 1990b vs. Monnet et al. 2010 for Acrochordiceras; Lehmann 1990). De Baets et al. (2013a) suspected dimorphism in Early Devonian Erbenoceras, but could not find evidence for it in a quantitative analysis of a larger sample (82 specimens). They found a bimodal size distribution, but the lower peak was not associated with adult modifications. Furthermore, morphs of both modes overlapped in several characters and already differed throughout earlier ontogeny, suggesting the presence of continuous variation rather than (sexual) dimorphism. Clearly more studies are necessary on intraspecific variability in several time intervals to fully understand the relative contribution of different types of continuous and discontinuous intraspecific variation (including dimorphism and polymorphism) in ammonoids. Such knowledge can only be achieved by quantitative studies on numerically large populations of precisely known geological ages derived from a wide variety of ages, paleoenvironmental or geographic areas, taxa and shell morphologies (cf. Tintant 1980; Davis et al. 1996). At the moment, it appears therefore most reasonable to assign co-occurring specimens to different species when no evidence is available for continuous variation with unimodal distribution or discontinuous variation in the form of morphs that evolve in parallel and/or co-occur with similar early ontogeny and/or later ontogeny, particularly in the Paleozoic. This interpretation might, however, change when additional material becomes available.

\subsubsection{Variation in the Suture Line}

While numerous studies have focused on intraspecific variability of shell shape and ornamentation, variation in the suture line has been less studied, particularly from 

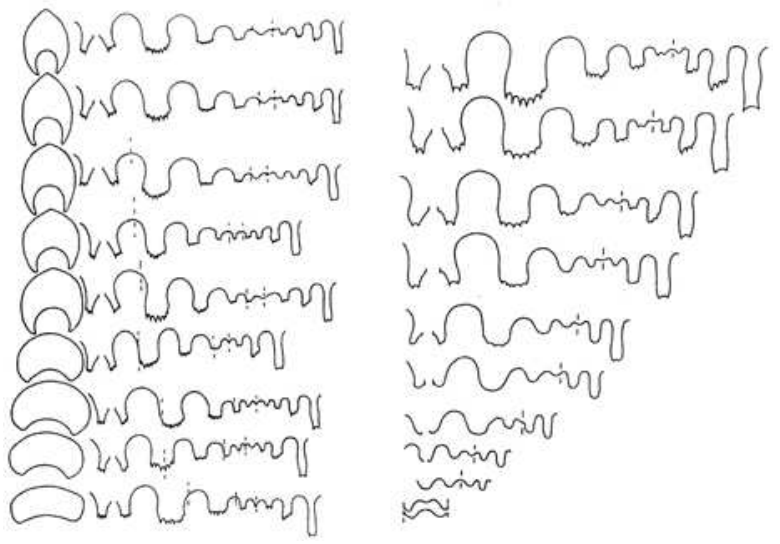

Fig. 9.11 Intrapopulation variation in the last whorl and sutures (left) and ontogenetic variation in the development of the suture line through ontogeny (right) in Tuaroceras rieberi from the Lower Anisian (modified form Dagys 2001)

a quantitative point of view. We herein discuss some intraspecific factors of suture line and septal variability.

The development of the suture line not only varies throughout ontogeny (Klug and Hoffmann 2015; Fig. 9.11) or on both sides of the plane of symmetry (asymmetry) within the same specimen (compare Klug and Hoffmann 2015; De Baets et al. 2015a), but can also vary between specimens of the same species at similar diameters (intrapopulational or intraspecific variation: e.g., Seilacher 1973; Dagys 2001; Fig. 9.11). Despite the common, perhaps over-emphasized use of the suture for taxonomic purposes (Arkell 1957), intraspecific variation in the suture line is only rarely studied quantitatively (Manship 2004, 2008; Waggoner 2006; Yacobucci and Manship 2011). Suture intraspecific variability appears to be particularly large in Jurassic and Cretaceous pseudoceratites (Arkell 1957) and heteromorphs (Kakabadze 2004). According to Arkell (1957), variation is the greatest among regressive types in which the suture line is secondarily simplified (e.g., in Jurassic and Cretaceous "pseudoceratites"). The suture line is also quite variable in several Mesozoic heteromorphs and might therefore be of little help for taxonomy (Kakabadze 2004), particularly at lower taxonomic levels (e.g., Hoffmann et al. 2009). Differences in suture line between specimens of the same species at a similar diameter have been related to differences in whorl shape (e.g., Arkell 1957; Reeside and Cobban 1960), ornamentation (e.g., Casey 1961; Westermann 1966) and/or ontogenetic development (e.g., Hammer and Bucher 2006), but they might also be more random (e.g., no clear correlation with other properties of the shell or ontogeny).

A marked variation of the suture line with whorl shape has been long known (e.g., Pictet 1854; Zittel 1885; Pfaff 1911; Spath 1919; Arkell 1957; Seilacher 1988; Klug and Hoffmann 2015), which manifests itself through the ontogeny of the same specimen or the evolution of taxa through time (reviewed by Monnet et al. 2011a). The phenomenon has been particularly discussed on large taxonomic scales, when 

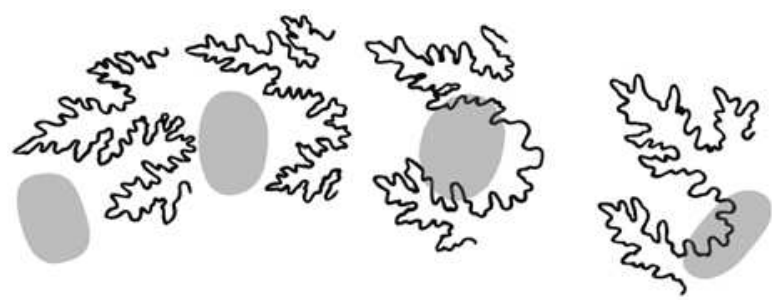

Fig. 9.12 Variation in four consecutive suture lines of the holotype of Cheloniceras disparile (Early Aptian) and its relationship with the position of the lateral tubercle (grey) (modified from Casey 1961, p. 216)

comparing taxa with different shell shapes (e.g., Westermann 1971; Ward 1980; Seilacher 1988; Jacobs 1990; Olóriz et al. 1997, 1999). Several authors have discussed complex covariations between shell morphology, ornamentation and/or suture line above the species level (e.g., Ward and Westermann 1985; Olóriz et al. 1997, 1999). Differences in the shape of the suture line between specimens of the same species at similar diameters have been less discussed. Pictet (1854, p. 669) already pointed out that the inflated varieties of a species often differed from the compressed ones in the number of accessory lobes (and that modification of the umbilicus can cause the same alteration of sutural element number). Reeside and Cobban (1960) found that more inflated and heavily ornamented forms within individual Neogastroplites species tended to have taller lateral saddles (see also Yacobucci and Manship 2011). Buckman (1892, p. 313) reported that in Sonninia and Amaltheus, the complexity of the suture varies with the ornament (and through the first law of covariation also with whorl cross section). Westermann (1966) dubbed the covariation of whorl cross section and number of lobes/ saddles 'Buckman's second law of covariation' (see Monnet et al. 2015a). He also stated that this might explain the statements of Oechsle (1958) on the moderately incised suture line of "S. adicra" and intensively incised suture line of "S. modesta", which he considered to be extreme variants of the same species. He suggested that the covariation between septal suture and shell plication could be explained by functional requirements ("the stiffening of the phragmocone against shear, a strongly incised suture line furnishing a better fixture of the septum against shear and more even distribution of stresses from the septum onto the outer shell vice versa"), particularly when this covariation could be demonstrated in multiple, not closely related genera. By contrast, Morard and Guex (2003) stated that the sculpture probably does not influence suture complexity directly, but that the sculptural and sutural elements both depend on a common third factor, the whorl shape (Guex 2001, 2003). Casey (1961) illustrated that the shape of the suture line at more or less the same diameter can also vary with ornamentation (tubercles) within the same specimen (Fig. 9.12). Some additional differences in the suture line within and between specimens can also be associated with pathologies (compare De Baets et al. 2015b; Keupp and Hoffmann 2015)

Hammer and Bucher (2006) tried to explain the correlation between whorl shape and suture line complexity partially in developmental terms in the following way: "Most ammonoids with compressed shells have more circular whorl sections early in ontogeny. The intraspecific variation in whorl shape can therefore be explained 
as heterochronic: the more rounded forms are retaining their juvenile shape and can be regarded as paedomorphic. In such forms, where development is delayed, it would not be surprising if sutural development was similarly delayed, retaining the simple suture line of the juvenile into more mature stages." They acknowledged, however, that "other physical mechanisms may also influence the fine shape of the suture". They also reported intraspecific variation in septal spacing within Amaltheus that correlated with whorl shape, which they explained functionally in terms of hydrostatic properties. The smaller interseptal spacing in the compressed form has a positive impact on hydrostatic consistency through chamber formation (i.e., the smaller septal spacing leads to a smaller relative loss of buoyancy and smaller rotations of the aperture between consecutive septae). Similar covariation was also reported in Dactylioceras by Morard (2004), where the septal distance (septal angle) was larger in evolute forms with a depressed whorl section than in involute forms with a compressed whorl section.

One of the prime examples of high continuous intraspecific variation in shell shape and ornamentation are Triassic faunas from Siberia (e.g., Dagys and Weitschat 1993a, b; Checa et al. 1996; Dagys et al. 1999; Dagys 2001; Weitschat 2008; Fig. 9.2, 9.11). Several of these authors report an absence or no straightforward relationship between shell shape and suture line within these species. An exception is Dagys (2001, p. 548), who reported that more compressed forms had the highest number of umbilical lobes, although in the systematic descriptions, he stated that the covariation of shell shape with the suture line was not straightforward (compare Fig. 9.13). Dagys and Weitschat (1993b) only reported that the position of the first saddle changes with the morphology of the conchs in Czekanowskites rieberi. Dagys et al. (1999) found that the outline of the saddles is highly variable in Parasibirites kolymensis.

Manship (2008) specifically investigated variation of the suture line in the Late Cretaceous acanthoceratoid Coilopoceras springeri, which has a marked intraspecific variation from robust, strongly ornamented to gracile, weakly ornamented shells. She found a subtle, gradational variation in suture forms, which was only weakly tied to shell morphology. Interestingly, Yacobucci and Manship (2011) reported a higher degree of constraint in the suture line pattern of the Cretaceous hoplitid Neogastroplites muelleri (known for its wide range of intraspecific variability in shell shape and ornamentation: Reeside and Cobban 1960; see Fig. 9.13) than in C. springeri. While overall there is much less variation in suture line than in shell shape and ornamentation in Neogastroplites, it is true that the "subglobose spinose" forms tended to have taller suture elements (compare Reeside and Cobban 1960).

Kassab and Hamama (1991) also figured the intraspecific variation in suture line in morphs with a depressed and compressed whorl shape of Libycoceras ismaeli showing no straightforward relationship with whorl shape. Morard and Guex (2003) reported, based on qualitative observations, that suture elements in involute morphotypes of the Early Jurassic ammonoid Osperleioceras tend to be more finely fringed and that the lateral saddle lies proportionally lower on the flanks in involute morphotypes. Similar qualitative differences were reported by Bersac and Bert (2012a, b) from Cretaceous Deshayesitidae. More quantitative analyses on large samples are necessary to further investigate these patterns of intraspecific variation in the suture line. 


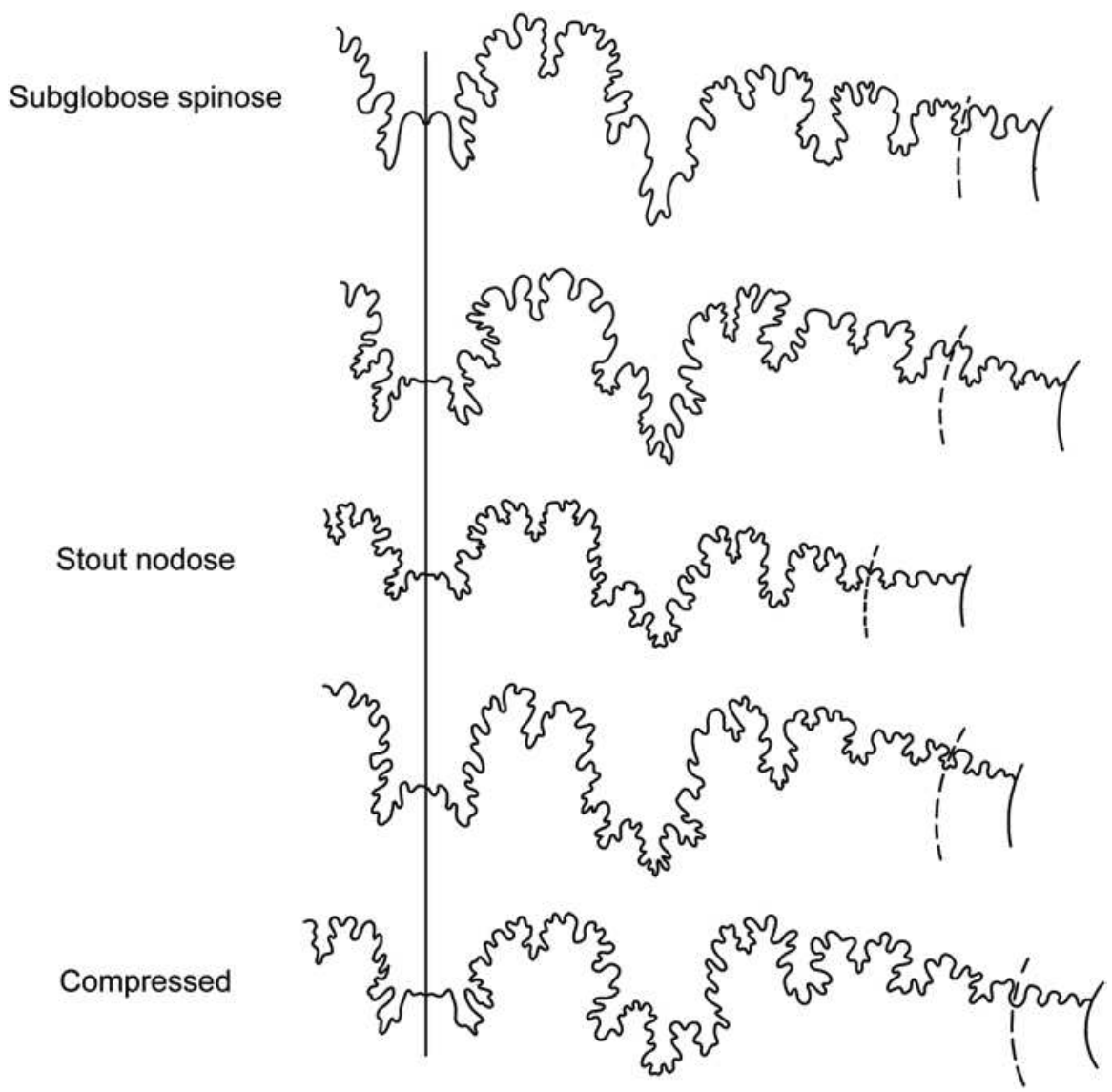

Fig. 9.13 Suture variation in morphs of Neogastroplites muelleri (Early Cenomanian). All sutures taken at shell diameters between 30 and $35 \mathrm{~mm}$. While some variations in the suture line appear correlated with shell shape (e.g., taller lateral saddles in more globose shells), other variation is uncorrelated with shell shape; the overall path of the suture line is similar in all forms. Suture patterns redrawn from Reeside and Cobban (1960). From top to bottom: Variant G, uncatalogued specimen; Variant E-F, USNM 129496; Variant C-D, USNM 129468; Variant B, USNM 129435; Variant A, USNM 129418

A special kind of intraspecific variation is the suture asymmetry (Kakabadze 2004; Paul 2011; Keupp 2012) in some taxa, which is reflected in the different position and development of the suture line elements between the left and right sides of the whorl. In at least some cases, this asymmetry could be related to asymmetrical development of the soft tissues (Yacobucci and Manship 2011). In some taxa, the symmetrical development of the suture line is poorly constrained and is very variable between different specimens (e.g., the labile position of the external lobe in some taxa: Lange 1929, 1941; Hölder 1956; Schindewolf 1961; Hengsbach 1976, 1980, 1986; Landman and Waage 1986; Keupp 2012 for a review), while in others, the development and direction of asymmetry seems to be genetically fixed (con- 
stant excentrical position of the lateral lobe in Platylenticeratidae and Anahoplites: Hölder 1956; Keupp 2012). The development of asymmetry in the suture can also be due to pathologies when it only appears in a small percentage of the population (some authors have linked this to parasitic infestations: see discussion in De Baets et al. 2015a).

\subsection{Influence of Intraspecific Variation on Ammonoid Studies}

Ammonoids have often suffered extreme taxonomic oversplitting (Kennedy and Cobban 1976; Kennedy and Wright 1985; Dagys and Weitschat 1993b; Donovan 1994), but lumping is also not uncommon (e.g., Westermann 1966; Howarth 1973; Callomon 1985). Underestimating (or overestimating) intraspecific variation can bias taxonomy and diversity counts, as well as biostratigraphic, evolutionary and paleobiogeographic analyses (e.g., Dzik 1985; Kennedy and Wright 1985; Hughes and Labandeira 1995; Nardin et al. 2005; Korn and Klug 2007; Monnet et al. 2010; De Baets et al. 2013a; Bert 2013).

Traditionally, many ammonoid workers have used a strict typological approach, erecting narrowly defined morphospecies, which has led to an artificial inflation of paleodiversity. Some authors like Buckman (1887) had already realized the problem early on, but still kept using this typological approach resulting in the oversplitting of species. A typical example of this approach is the Jurassic ammonite Sonninia, for which Buckman alone erected over 60 species. Westermann (1966) subsequently lumped 69 species of Sonninia (including the ones erected by Buckman) together with Sonninia adicra as they all form part of a continuum in morphology (as well as dimorphism) and based on this work, defined the Buckman laws of covariation following observations that had already been reported by the former author in 1892. Although a large degree of intraspecific variability in Sonninia is still accepted, it is now well established that specimens of Sonninia lumped together by Westermann (1966) come from multiple (bio)stratigraphic levels (e.g., Callomon 1985; Westermann 1996; Sandoval and Chandler 2000; Dietze et al. 2005). When better preserved or better stratigraphically controlled material becomes available, this can still lead to the erection of additional species or the re-establishment of older ones based on previously overlooked differences in ontogeny or morphology. Hence, we frequently see in the history of ammonoid taxonomy an initial rapid increase in taxonomic diversity as a result of taxonomic oversplitting related to a strict typological approach, followed by a decline and then potentially a slight rise in diversity again, when a better numerical grasp on intraspecific variability and even finer stratigraphic resolution is achieved, as illustrated by Buckman's Sonninia (Fig. 9.14).

In the middle of the last century, various authors realized the problems related to a strict typological or morphospecies approach, which resulted in the introduction of multiple co-occurring species at the same stratigraphic interval and region (e.g., 


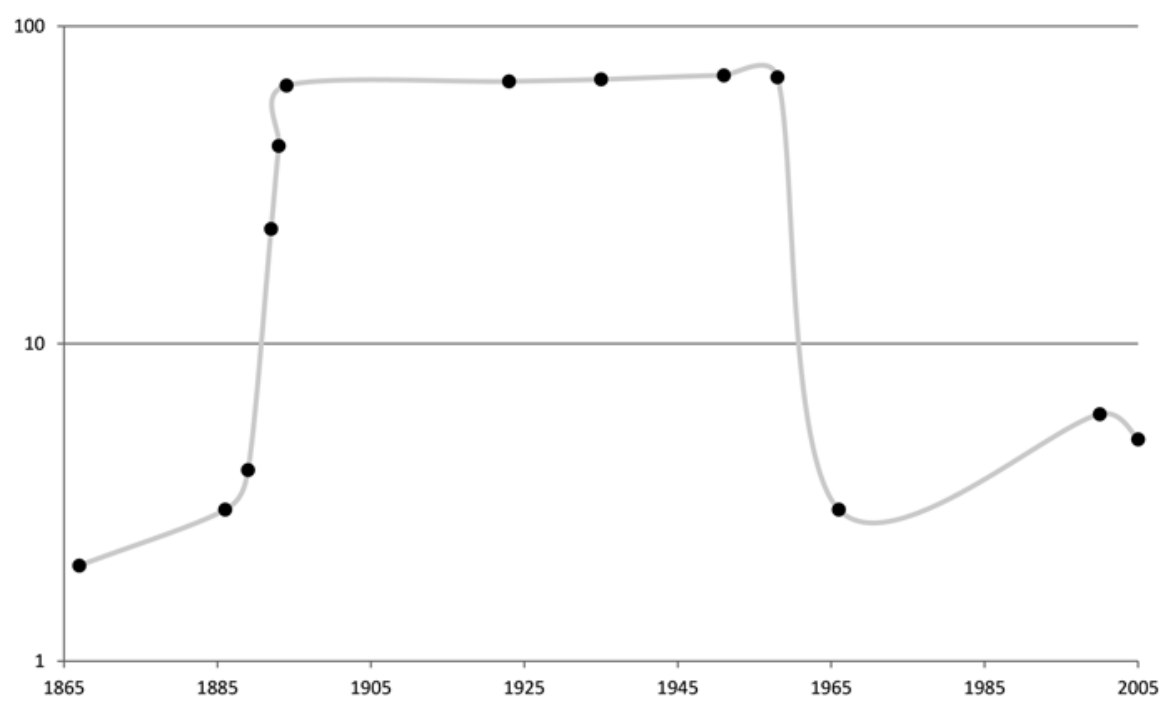

Fig. 9.14 Number of species of Sonninia (Bajocian) in use through time. Note the steep growth in the beginning during the era of a strict typological approach (mostly erected by Buckman), followed by a steep decline due to the biospecies approach of Westermann (1966) and a slight increase in modern times as a result of a more highly resolved stratigraphic framework and the discovery of new material (Sandoval and Chandler 2000; Dietze et al. 2005)

Haas 1946; Barber 1957; Callomon 1963; Tintant 1963; Westermann 1966), and have rallied for a more 'biological' species concept. Multiple authors have promoted the merits of using a horizontal (population or biospecies) approach as opposed to a vertical (index or morphospecies) approach (e.g., Callomon 1963, 1985; Tintant 1963, 1976, 1980; Tozer 1971; Kennedy and Cobban 1976; Silberling and Nichols 1982; Dzik 1985, 1990a, 1994; Westermann and Callomon 1988; Atrops and Meléndez 1993; Chandler and Callomon 2009; Fig. 9.15), which does not only include a wide range of continuous variation, but potentially also discontinuous variation (sexual dimorphism and non-sexual polymorphism). These authors may explicitly or implicitly claim that a fossil assemblage from a single stratigraphic horizon is more likely to represent a true biospecies (i.e., a reproductively isolated population) than assemblages from different horizons. However, it is obviously difficult to test claims about reproductive isolation in fossil samples, and we suggest great caution in applying the term biospecies to extinct taxa (see Yacobucci et al. 2015).

Oversplitting might also artificially create two or more lineages evolving seemingly in parallel (Tintant 1980; Atrops and Meléndez 1993). Many authors keep using morphological species or variants to refer to different morphologies or morphs of these species for practical purposes (e.g., Dietze et al. 2005; Chandler and Callomon 2009), but it is incorrect to give these forms the rank of subspecies from a biological point of view (where species need to be reproductively isolated by geography or other factors), following the International Code of Zoological Nomenclature. Similar views were expressed for the subgeneric ranking of dimorphs (e.g., 


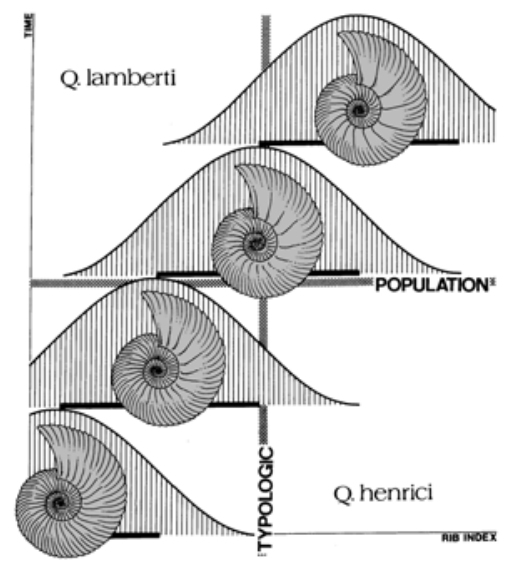

Fig. 9.15 Differences between typological and population concepts of an ammonoid species as demonstrated by Late Callovian Quenstedtoceras. According to a typological approach all specimens having more than three secondary ribs per primary rib belong to $Q$. lamberti (irrespective of their age), while according to a population approach all populations showing modal values of the rib index exceeding 3 at size class 50-60 are to be included in that species (modified from Dzik 1990a; with permission from the author)

Schweigert et al. 2007), which should not be used because a subgeneric placement should express (paleo-) biogeographic or habitat differentiation within a genus rather than pure morphological differences. Nomenclatorial reasons also speak against the use of a subgeneric ranking (e.g., Pavia 2006).

Not properly taking intraspecific variation into account can cause obvious problems for taxonomy and systematics, but it can also significantly influence biostratigraphic studies (Dzik 1985, 1990a). As explained by Dzik (1985), the probability of finding a particular morphotype in a sample is not only related to the sample size but also to the horizon being sampled, as different morphotypes are more common in different horizons (Fig. 9.15). Thus, definitions of time correlation units based on the first known occurrence (FAD) of a morphotype does not provide a completely reliable basis for a study, which has led to the common use of assemblage zones. Morphological variation in contemporary populations might greatly exceed evolutionary changes between successive faunas (e.g., Schloenbachia: Kennedy and Cobban 1976, Wilmsen and Mosavinia 2011; Kennedy 2013 or Neogastroplites: Reeside and Cobban 1960, Reyment and Minaka 2000), so that in many cases, successive faunas can only be separated on the basis of the mode of variation of the population, as individual morphotypes have relatively long stratigraphic ranges. This might also make it difficult to compare specimens from different localities or regions, when only limited material is available (e.g., De Baets et al. 2013a). Properly taking into account intraspecific variability is therefore a very important prerequisite for studying temporal and spatial patterns of diversity through time and their relation with environmental changes and extinction events (e.g., Kennedy and Wright 1985; Monnet et al. 2011b; De Baets et al. 2013a), for which ammonoids are 
often used (e.g., Brayard et al. 2009; Dera et al. 2011). This problem is illustrated by a study of Korn and Klug (2007) on the intraspecific variability of Manticoceras, which indicates that the effect of the Frasnian-Famennian extinction on ammonoids might be significantly overestimated when ignoring intraspecific variability. Frasnian diversity is based mainly on manticoceratid diversity, which was artificially inflated by taxonomic oversplitting (Korn and Klug 2007). Clearly, analysis of intraspecific variability is a prerequisite for many paleobiological and evolutionary studies (e.g., Monnet et al. 2015b), and much more research in this field is needed.

\subsection{Intraspecific Variation through Ontogeny}

The mode and range of intraspecific variation might change through ontogeny. Several authors have reported the largest range of continuous intraspecific variation from the middle whorls (e.g., Dagys and Weitschat 1993b; Morard 2004, 2006; Korn and Klug 2007; De Baets et al. 2013a). In these cases, specimens of the same species (and even different species and genera) are morphologically more similar to each other in the last whorl (recognized by adult modifications discussed in Klug et al. 2015) and early whorls than during intermediate growth stages. Others have reported higher variation in juvenile and adult forms (e.g., Korn and Vöhringer 2004). Tanabe and Shigeta (1987) reported a higher variation in early whorls than in later whorls in several Cretaceous ammonoid taxa, although they only investigated a limited number of specimens per species. Monnet et al. (2012) reported also the same pattern of decreasing intraspecific variation through ontogeny (i.e. high juvenile plasticity) in some Triassic ammonoids that is also independent of evolutionary trends through time and also may have a very different variance (range) in different morphological characters. However, this pattern must be cautiously treated because it may be biased by the usual higher abundance of intermediate-sized specimens within preserved "populations" of species. The most extreme example of large differences in adult form is the dimorphism in late ontogeny typical of sexual dimorphism (Klug et al. 2015). There are also examples of non-sexual polymorphism, where the forms are at their most dissimilar in earlier ontogeny and become more similar in later ontogeny (e.g., in Dactylioceras as discussed by Tintant 1976, 1980) or where they have similar ontogenies differing only in discrete characters (compare Sect. 9.4.2) Furthermore, a large degree of intraspecific variation in ammonoids might be related to differences in development, more specifically growth rates and the length and shape of ontogenetic trajectories through development. For these reasons, intraspecific variability should be studied throughout ontogeny or development from early to late growth stages (e.g., Neige 1997; Morard and Guex 2003; Urdy et al. 2010a, b, 2013; De Baets et al. 2013a; Bert 2013: compare Urdy 2015). Only limited studies have focused on quantitatively analyzing changes in intraspecific variation throughout ontogeny (e.g., De Baets et al. 2013a), but they might be particularly important to understand the mode of growth as well as paleobiology and paleoecology of ammonoids. 


\subsection{Size-At-Age Variation in Ammonoids}

The growth of extant cephalopods is notoriously variable and is influenced by various biotic and abiotic factors. Populations of extant cephalopod species can show large intra-annual (seasonal) and inter-annual variations in growth rate and adult size (e.g., Boyle and Ngoile 1993; Arkhipkin and Laptikhovsky 1994; Nigmatullin et al. 2001; Jackson and Moltschaniwskyi 2002; Arkhipkin 2004; Keyl et al. 2011; Hoving et al. 2013). This typically results in a high intraspecific variation in size-at-age data (e.g., Boyle and Boletzky 1996), which has been corroborated both by laboratory rearing experiments and population studies in the field (Pecl et al. 2004 and references therein). In particular, ambient temperature as well as food quality and quantity have been implicated in growth rates (e.g., Pecl et al. 2004), but various other environmental factors such as light intensity, pressure, dissolved oxygen, and the abundance and kind of predators might have stressed or otherwise influenced the growth rates of marine organisms (see Bucher et al. 1996 for a review). Food and temperature are also partially interrelated because feeding rate is a function of temperature (Mangold 1983; Hewitt and Stait 1988). Such ecologically driven differences in size are exemplified by a study by Hoving et al. (2013), who recorded a spectacular decrease in the adult size of the jumbo squid (Dosidicus gigas) from more than $55 \mathrm{~cm}$ to less than $30 \mathrm{~cm}$ mantle length after an El Niño event, which is a periodic development of anomalously warm surface water temperatures (and can coincide with a reduction in primary production associated with wind-driven upwelling as well as a variety of effects on higher trophic levels) off the western coast of South America. This variation might also be partially related to differences in temperature or other environmental conditions at hatching. Climate change might also affect the life history of squids as warmer temperatures are expected to reduce embryonic duration and hatchling size, increase growth rates and shorten the overall life-span, resulting in maturation at smaller sizes and younger ages. Individual squids will require more food per unit body size, need more oxygen for faster metabolism and have a reduced capacity to cope with food scarcity (Pecl and Jackson 2008). Climate change might well have affected ammonoid populations in a similar way (e.g., Matyja and Wierzbowski 2000), although this needs be further investigation.

Similar size-at-age variation might have existed in ammonoids, and could be reflected in differences in adult size of fossil ammonoid populations at the same locality and age (e.g., Ivanov 1971a, 1975: microconchs, macroconchs and megaconchs; Matyja 1986, 1994: miniconchs, microconchs and macroconchs: compare Klug et al. 2015), over evolutionary time (Hewitt and Hurst 1977; Dzik 1990a; Landman et al. 2008) as well as interpopulational differences in adult size between different regions and/or paleoenvironments (Kummel 1948; Vogel 1959; Wendt 1971; Mancini 1978; Elmi and Benshili 1987; Stevens 1988; Courville and Thierry 1993; Mignot 1993; Mignot et al. 1993; Matyja and Wierzbowski 2000; Reboulet 2001; Urlichs 2004, 2012; Ploch 2007; Landman et al. 2008). It should be noted, however, that it can be hard to disentangle intra- and inter-annual environmental factors 
due to the inherent time-averaging each shell assemblage (fossil population) has gone through (compare Sect. 9.3). Also, to document size-at-age variation requires a method for determining the age of individuals. Even in extant cephalopods, estimating age (often indirectly using growth increments in statoliths: Jackson 1994) and maturity (e.g., Arkhipkin 1992) is not always straightforward. In fossil cephalopods, such studies are further complicated. Diameter is most commonly used as a proxy for size, although other parameters like body chamber (or shell) volume or its square root might be more suitable, as they better reflect the growth of the soft tissues contained within the body chamber, particularly when comparing taxa or ontogenetic stages with different shell shapes (e.g., Bucher et al. 1996; Dommergues et al. 2002; De Baets et al. 2013a). The volumetric parameters are more difficult to obtain and not commonly used in the literature, making the diameter still the most commonly used proxy for size. The diameter is also not directly comparable with mantle length, which is the most widely used measure of size in extant coleoids. The body chamber length would be more directly comparable with mantle length. The diameter has been used more rarely as a proxy for age, but this probably makes even less sense. Other proxies for age have been employed like septal spacing (e.g., Stephen et al. 2002) or rib spacing counts (e.g., Dommergues 1988), although these also have their problems as they are based on several assumptions and do not necessarily stay constant through ontogeny or between taxa (compare Bucher et al. 1996). Ideally, we would need to know growth rates through ontogeny, which are, however, hard to estimate in fossil organisms like ammonoids. Several methods making various assumptions have been suggested, which can often only be used in particular cases and show various degrees of success and reliability (comprehensively reviewed in Bucher et al. 1996; compare Urdy 2015). These methods are:

- Assumptions about the periodicity of shell secretion in septa, constrictions or pseudosutures (e.g., Ivanov 1971b; Hirano 1981; Doguzhaeva 1982; Weitschat and Bandel 1991; Hewitt et al. 1991),

- Detection of seasonal signals in morphology (e.g., shell volume: Trueman 1940; rates of whorl expansion and septal spacing: Westermann 1971; septal spacing: Kulicki 1974; Zakharov 1977; jaw increments: Hewitt et al. 1993) and isotopic data (e.g., Jordan and Stahl 1971; Lécuyer and Bucher 2006),

- Presence of distinct age classes or cohorts in ammonoid species, which are assumed to have bred (and spawned) periodically at regular times (e.g., Trueman 1940; Bucher et al. 1996),

- Using growth rates of epizoans with modern counterparts growing on ammonoids during their lifetime (e.g., Schindewolf 1934; Merkt 1966; Meischner 1968; Hirano 1981; Andrew et al. 2011).

Some of the most pronounced size differences in ammonoids might be associated with sexual dimorphism (classically expressed as microconchs and macroconchs), although the sexual nature or presence of dimorphism is not always clear, even during the Jurassic where the phenomenon is most accepted (compare Sect. 9.4.2). Some authors have reported only one morphology, resembling microconchs and/ or macroconchs of other taxa, while others have reported the presence of three 
morphologies (e.g., Ivanov 1971a, 1975; Brochwicz-Lewinski and Rózak 1976; Matyja 1986, 1994) within ammonoid species (compare Klug et al. 2015). The latter phenomenon might reflect the presence of morphologically distinct "populations", which might be largely geographically isolated or represent cohorts hatched at different times (and which were therefore subjected to different environmental conditions at different times in their development). Ivanov (1971a, 1975) reported the presence of megaconchs, which do not show signs of maturation (although this might potentially be a taphonomic bias) and Matyja $(1986,1994)$ reported the presence of miniconchs in addition to microconchs and macroconchs within some ammonoid taxa. The presence of more than two morphologies does not necessarily rule out the presence of sexual dimorphism as there might be more than one morph in one or both sexes. Interestingly, the presence of three adult size-classes has also been reported from extant cephalopods (e.g., Sthenoteuthis pteropus: Zuev 1976; Dosidicus gigas: Nigmatullin et al. 2001), although it probably does not reflect sexual dimorphism, as the three size classes occur in both sexes (Nigmatullin et al. 2001). Matyja $(1986,1994)$ has dubbed this phenomenon developmental polymorphism, but this does not necessarily correspond to the biological definition of polymorphism, as these might have lived in different times or places and might therefore not be polymorphic in a biological sense (as such forms could represent seasonal or geographic variants: compare Sect. 9.3). Matyja (1986) attributed the expression of "developmental polymorphism" as mono-, di- or trimorphism in a given population to environmental factors, more specifically geography and lithofacies. Nevertheless, one should remain cautious in interpreting size structure in fossil populations as various factors could also contribute to a non-unimodal size distribution of fossil assemblages, including taphonomic and collection biases (size sorting, spatial and temporal mixing) as well as paleoecological factors (different ratios or separation of size classes or ontogenetic stages during the lifetime). The studies of Matyja (1986, (1994) and Ivanov (1971a, 1975) are therefore open to scrutiny as they did not use the proper quantitative methods and have a low sample size (compare Callomon 1988: Davis et al. 1996).

Several authors have reported intraspecific differences in adult size of populations deriving from different regions and/or paleoenvironments (Elmi and Benshili 1987; Mignot 1993; Mignot et al. 1993; Reboulet 2001; Urlichs 2004; Ploch 2007; Landman et al. 2008). Many of these studies have suggested a correlation between miniaturization and a locally confined paleogeographic and/or paleoenvironmental context (e.g., Elmi and Benshili 1987; Mignot 1993; Mignot et al. 1993; Olóriz et al. 2000; Urlichs 2004; Ploch 2007). Such a relationship has been particularly supported by comparative studies on Tethyan populations of Jurassic ammonites from small basins in the northwest European platform (e.g., Elmi and Benshili 1987; Mignot 1993; Mignot et al. 1993). Stunting ("Kümmerwuchs" sensu Ager 1963; see Keupp and Hoffmann 2015) preferentially affected populations in small isolated basins, which belong to species that are widespread and have larger individuals outside of the confined basins. Dommergues et al. (2002) attributed this size decrease to the scarcity of nutrients because such stunting is found experimentally in miniaturized (undernourished) cuttlefish (Boletzky 1974), although such 
populations have so far not been reported from natural environments. Reboulet (2001) reported that representatives of several Valanginian ammonoid species in the deeper water facies of the Vocontian basin were smaller than their counterparts in the shallow water facies in the Provence Platform, which he attributed to a decrease in growth rate under conditions of higher hydrostatic pressure as well as lower water temperature and nutrient supply in the basinal areas. Ploch (2007) reported that specimens of Saynoceras verrucosum from the deeper Vocontian basin were smaller than those from the shallower epicratonic Polish basin, which she attributed to their isolation and differences in depth or temperature. Landman et al. (2008) investigated differences in body size of the Late Cretaceous Hoploscaphites nicolletii over time and between geographically separated contemporary populations. They reported that macroconchs from the northwestern portion of their study area were smaller than those from the southwestern portion, which they explained by unfavorable conditions (lower oxygen levels, less than normal marine salinity) also reflected in the low diversity and abundance of nektic and benthic organisms in general. Landman et al. (2008) also reported that body size of the same species correlated with environmental changes over time. Urlichs (2004) discovered that smaller Triassic Lobites nautilinus/pisum specimens occurred in distinct clay to marly clay beds rich in pyrite while larger specimens were found in marl and limestone beds poor in pyrite. He interpreted the larger specimens as normal-sized when compared with contemporary specimens from the Hallstätt Limestone and the smaller specimens as stunted adults based on septal crowding (compare Kraft et al. 2008 for an alternative interpretation). Interestingly, the environment did not seem to have affected several other species (e.g., Lecanites glaucus, Megaphyllites jarbas, Proarcestes klipsteini, etc.), which are represented by normal-sized juveniles. Often, other shelled organisms from the St. Cassian Formation such as bivalves and brachiopods (Urlichs 2012) or in other, similar faunas are miniaturized (e.g., Kummel 1948; Mancini 1978). Urlichs interpreted this as a possible indication for a nektobenthic or demersal mode of life of Lobites and the confined paleogeographic condition of this basin. The close correlation between body size and paleoenvironment has often been used to indicate a deep nektonic or demersal/nektobenthic mode of life (Reboulet 2001; Urlichs 2004), although it might similarly affect forms with a pelagic mode of life as both facies and body size might be influenced by a second factor that controls both.

Stunting ("Kümmerwuchs"), which has ecological reasons, should not be confused with dwarfism ("Zwergwuchs"), which is genetically fixed (compare Ager 1963; Hallam 1965; Mancini 1978; Urlichs 2004; Keupp 2012). Paedomorphic processes that might lead to evolutionary trends towards smaller representatives are not uncommon in ammonoids, although they are often discussed above the species level (e.g., Dommergues et al. 1986; Landman and Geyssant 1993; Korn 1995). Logically, the first thing one needs to rule out in miniaturized faunas is that their small size does not relate to an early stage of development (e.g., juveniles) or taphonomic bias (e.g., only inner whorls preserved). Some authors have reported smaller representatives of species from fissure-fillings compared to 'normal' individuals from other sediments in the Triassic (e.g., Krystyn et al. 1971; Urlichs 2004) and the Jurassic 
(e.g., Wendt 1971; Aubrecht and Schlögl 2011). Some have attributed this to taphonomic biases (preferential preservation of smaller specimens in these fissures: Krystyn et al. 1971), while others attributed these to stunting (Wendt 1971; Urlichs 2004). Aubrecht and Schlögl (2011) could not establish whether these ammonites were juvenile, dwarfed specimens adapted to limited cave space or size-sorted adult specimens. According to Stevens (1988), environmental constraints could, however, also lead to gigantism in adults; using recent squids as a model, he predicted that large specimens might have preferred colder environments and should therefore be more numerous in the fossil record during transgressive episodes. Rare abnormally large or "giant" specimens within an ammonoid species could potentially be the outcome of pathological conditions such as parasitic castration, in analogy with cases seen in extant gastropods, or hormonal disorders (Dommergues et al. 1986; Stevens 1988; Manger et al. 1999; this is discussed in more detail in De Baets et al. 2015a).

Environmental factors do not explain all variation in size-at-age, as individuals reared under identical conditions still display a wide range of sizes (Pecl et al. 2004). Many studies have attributed size-at-age variation to intrinsic factors or environmental factors affecting cephalopods after hatching, overlooking the effect of seasonal temperature variation and individual hatching size heterogeneity. Such differences in hatching size might amplify throughout the lifespan of the cephalopods. In Recent cephalopods, hatchling size not only depends on egg size, but also on developmental temperature (varying with seasons, depth or latitude) and individual hatching conditions (Boletzky 2003). A negative relationship between egg size and environmental temperature is known from extant cephalopods and has been reported both within species and between species (e.g., Laptikhovsky 2006). Latitudinal temperature-related differences in embryonic shell size might also have been present in ammonoids (Laptikhovsky et al. 2013), but so far, the fossil record is spatially too patchy to test geographic differences in contemporary populations of the same species over large latitudinal distances, where this could be relevant (Tajika and Wani 2011). In extant cephalopods, there is also a large intrinsic variation at hatching at the same locality (De Baets et al. 2015b), which might also contribute to the large intraspecific variation reported in various ammonoids sampled from restricted intervals in time and space from the Paleozoic (Erben 1950, 1964; Tanabe et al. 1995; Stephen and Stanton 2002) to the Mesozoic (Tanabe 1977a, b; Landman 1987; Rouget and Neige 2001; Tanabe et al. 2003; Tajika and Wani 2011). It has been hypothesized that both seasonal temperature variation and individual hatchling size heterogeneity might influence subsequent growth and contribute to the (adult) size-at-age variation of cephalopods (Pecl et al. 2004; Leporati et al. 2007). Pecl et al. (2004) hypothesized that small changes in temperature might be particularly relevant during the early exponential growth phase and then amplify throughout the lifespan. An exception might be longer-lived species that exhibit asymptotic growth, where small initial differences between individuals might be minimized as the organisms grow. Individual hatchling variation might, however, play a subordinate role, at least in some ammonoids such as Scaphites (Landman 1987) or Creniceras renggeri (Neige 1997), where authors reported a lack of corre- 
lation between size at hatching and adult size. Nevertheless, such correlations might still be present earlier in ontogeny or in other taxa, as the influence of range of variation in early ontogeny seems to depend on the growth pattern of the cephalopods.

All these studies demonstrate that size is a highly variable parameter among populations within ammonoid species when subjected to specific environmental constraints. This indicates that size can be a useful tool to recognize spatially separated fossil populations (e.g., Courville and Thierry 1993). However, size-at-age may not be an effective criterion to separate ammonoid species. For example, the only character separating "Mimagoniatites falcistria" (restricted to the Hunsrück Slate) from M. fecundus (more widely distributed) was its size, combined with differences in preservation between clayey and carbonate sediments (Chlupáč and Turek 1983; Göddertz 1989). More complete specimens of " $M$. falcistria" with preserved inner whorls show that they are conspecific with M. fecundus (De Baets et al. 2013b). De Baets et al. (2013b) could also demonstrate that the larger specimens from the Hunsrück Slate show indications of adulthood (Chlupáč and Turek 1983), while larger, complete specimens are rare or absent in its type region in the Czech Republic.

\subsection{Ecophenotypic Variation}

Intraspecific morphological variation has been well-documented, particularly in coiled Mesozoic ammonoids, but it still remains poorly understood from an ecological point of view (e.g., Westermann 1996; Ritterbush et al. 2014). Strong intraspecific variation without apparent facies association has often been used to question a close correlation between shell shape and ecology in ammonoids (Dagys and Weitschat 1993a, b; Dagys et al. 1999; Weitschat 2008; Kennedy and Cobban 1976; compare Naglik et al. 2015). Others have suggested it might be related to a lack of selection on shell shape in these taxa and/or certain environments (Kennedy and Cobban 1976; Westermann 1966, 1996; Keupp 2000). The occurrence of broadly varying species together with narrowly varying species in the same family (e.g., Czekanowskites with Arctohungarites: Dagys and Weitschat 1993a) or cooccurring in the same strata (Sonninia with Fissilobiceras: Dietze et al. 2005) has been used by some authors (Westermann 1996; Keupp 2000) to suggest differences in selection pressure on streamlining and/or "defensive" sculpture depending on the paleoenvironment. Westermann (1996) hypothesized that streamlining varied much more in populations of planktic drifters and vertical migrants compared with nektic and demersal swimmers that "depended on speed, acceleration and/or steerage for catching prey". Keupp (2000) suspected that forms showing high variation might have lived in shallower water with higher water energy, where they would have been exposed to stronger selection for forms with better "streamlining" (Naglik et al. 2015). Interestingly, other ammonoid workers have related shell shape strictly to environmental influences as fossil taxa that show an array of forms are often assumed a priori to be ecophenotypically plastic (e.g., Crick, 1978; Kassab and Hamama 1991; Reyment 1988; Reyment and Kennedy 1991; Kin 2010), even if 
the specimens are more or less contemporary and derive from the same locality or region (Reyment and Kennedy 1991; Kin 2010). On the other hand, shell morphology is not necessarily strongly controlled by environmental conditions. Callomon (1985), for instance, noted that a high range of morphological variation in the Jurassic cardioceratids persisted for several million years despite migrations and changes in habitat, suggesting that internal controls on shell shape also existed. Some authors (Reyment 1988; Reyment and Kennedy 1991; Reyment 2003) have attributed the pronounced variation observed in some ammonoids to genetically based, "multiple niche polymorphism" (Bulmer 1980) in stressful environments, which is common in modern gastropods (Goodfriend 1986), although this is hard to prove.

Differences in intraspecific variation between different paleoenvironments and regions have rarely been studied in ammonoids, although they are the only way to test hypotheses of phenotypic plasticity and ecophenotypic variation in ammonoids. Some authors have not only reported intraspecific differences in size (discussed in more detail above in Sect. 9.7), but also differences in shell morphology and/ or ornamentation between different paleoenvironments (Dietl 1978; Tintant 1980; Courville and Thierry 1993; Jacobs et al. 1994; Diedrich 2000; Ploch 2007; Wilmsen and Mosavinia 2011). Potentially, this link between shell form and environment might also be related to differences in growth rates and development between localities (Mignot et al. 1993; Reboulet 2001). Phenotypic plasticity in shell shape and ornamentation has mainly been reported in several Cretaceous ammonoids (e.g., Jacobs et al. 1994; Reyment and Kennedy 1991; Diedrich 2000; Kin 2010, 2011; Machalski 2010; Wilmsen and Mosavinia 2011; Fig. 9.16). Unfortunately, most of these studies only semi-quantitatively investigated these patters (i.e., in categories), having access only to rather small sample sizes, or they did not list the original measurements of their specimens, which would make it possible to assess these patterns statistically. In any case, phenotypic plasticity can never be fully demonstrated for ammonoids, since it would require proof that morphologically differing individuals shared the same genome (which is obviously unknown from ammonoids) and varied due to differing ecological conditions.

Jacobs et al. (1994) reported the presence of more compressed morphs of Scaphites whitfieldi in nearshore sandy facies, while more depressed morphs of this species occurred in offshore muds. The phenomenon of shell compression varying with lithofacies has also been recognized above the species level (Jurassic: Bayer and McGhee 1984, 1985; Cretaceous: Landman and Waage 1993; Kawabe 2003). This is seemingly consistent with a hydrodynamic explanation, where thinner, more compressed morphs would be able to swim more efficiently at higher velocities (typical for nearshore environments) and depressed morphs more efficiently at low velocities (see Naglik et al. 2015). A similar phenomenon might be present in Thomasites gongilensis, for which Courville and Thierry (1993) reported a continuous intraspecific variation from extreme platycone (compressum), over intermediate morphologies (tectiforme), to subsphaeroconic or subcadiconic morphologies (gongilense) linked by intermediate forms. The main morphology also depended on the paleoenvironments, with more compressed platycones dominating in shallower areas, while more inflated morphs dominated in deeper, subsiding areas (tectiforme 


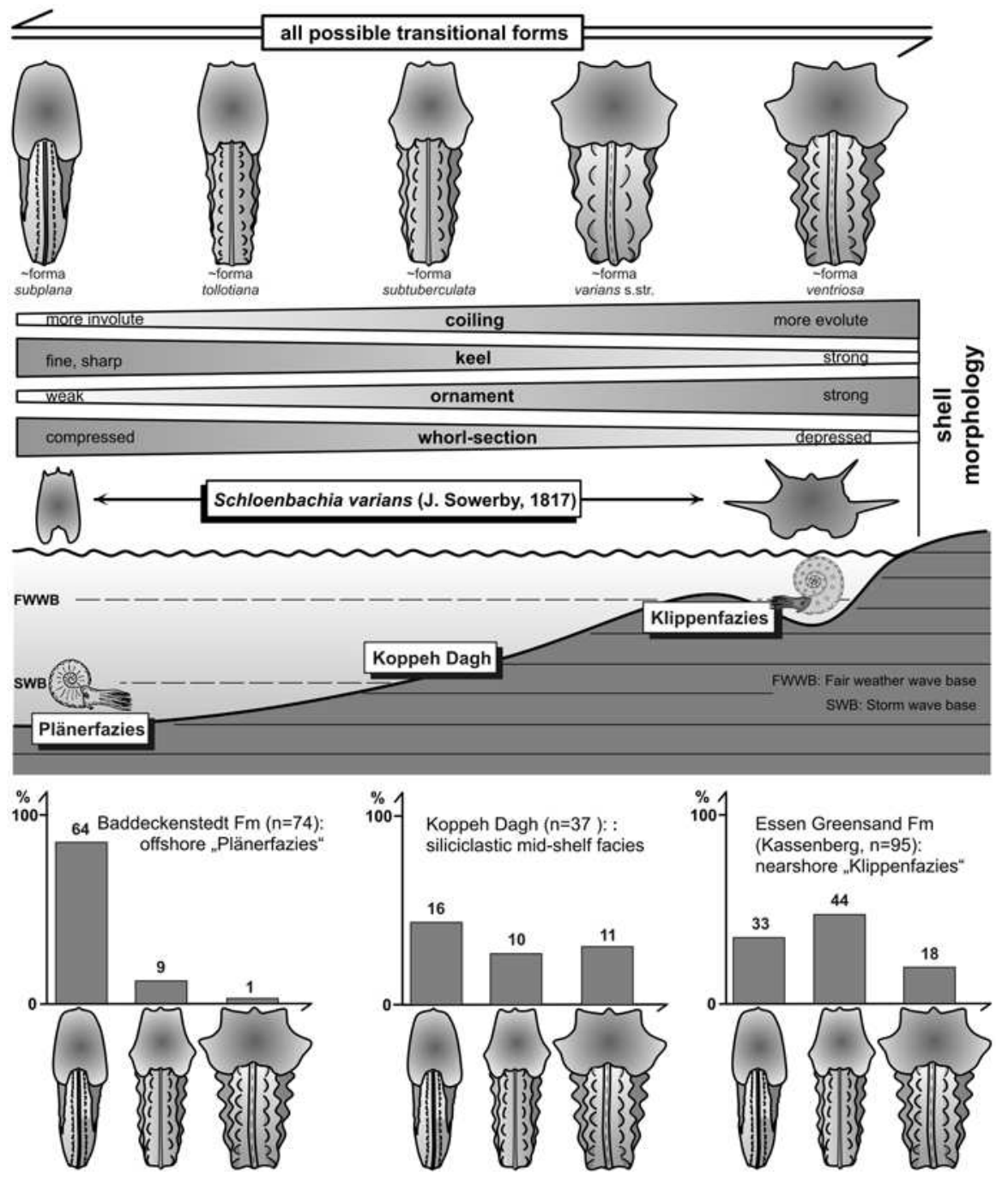

Fig. 9.16 Schematized distribution and semi-quantitative analysis of the relative proportion of morphological variants within contemporary samples of Schloenbachia varians (Cenomanian) from different paleoenvironments (modified from Wilmsen and Mosavinia 2011; with permission from the author)

and gongilensis). The situation might have been even more complicated as they also found a group (inflatum), which differed in ornamentation (branching of ribs and presence of furrows) and which they assigned to the same species; this species did not show this ecophenotypic variation (compare Reyment 2004 for a different point of view). Courville and Thierry (1993) speculated that the inflatum group might have been a geographic subspecies or a more complex case of extreme intraspecific variation as both groups were only occasionally found together in a transitional 
area between both regions, where these morphs are typical (compare also Reyment 2003). There might also be a link with development as the representatives of the species from different localities showed markedly different body sizes. The authors explained this by internal (genetic) factors as well as external constraints (water depth and energy, interactions with other organisms including predation and competition for food).

Complicating the situation, Wilmsen and Mosavinia (2011) reported the opposite pattern in Schloenbachia varians, with compressed, weakly ornamented morphs being more common in open (and deeper) waters and depressed, strongly tuberculate forms in shallower environments (Fig. 9.16). They attributed the dominance of strongly tuberculate, depressed forms in shallow, nearshore environments to higher water energy and predation pressure. They only studied this semi-quantitatively, but their histograms suggest non-unimodal and strongly skewed distributions in some paleoenvironments. A similar type of ecophenotypic variation was reported by Diedrich (2000) for Pusozia, where finely ribbed ecotypes are typical for ramp facies in the deeper shelf, more coarsely ribbed varieties for slope environments of the middle shelf and heavily ornamented forms for shallower submarine swells. He attributed the facies-dependence of shell morphology to the nektobenthic or demersal ecology of the ammonoids in question (similar claims have been made for facies-dependence of size: Reboulet 2001; Urlichs 2004). Even if a relationship between shell morphology and an environmental factor can be shown, such a link does not by itself prove that morphology is controlled by that factor (Yacobucci 2008). For example, given a correlation between shell shape and facies, the underlying cause of the differing shell shapes is certainly not the facies per se, but rather one or more associated factors, such as the water energy, predatory pressure, hydrostatic pressure, light, nutrient availability, geographical region, or stage of a sea-level cycle in which the ammonoids preferentially lived. These components might be difficult to disentangle in fossil "populations" as they are typically mixed in time (different seasons, years or decades to hundreds and thousands of years; natural and empiral time-averaging of shell assemblages) and space (bathymetrically, geographically, paleoenvironmentally; due to their pelagic lifestyle as well as potential post-mortem transport: Kennedy and Cobban 1976; Ritterbush et al. 2014; Naglik et al. 2015). Reyment and Kennedy (1991) and Kin (2010, 2011) discussed phenotypic plasticity as a possible reason for the large intraspecific variation in Knemiceras and Acanthoscaphites, respectively. They could not, however, provide evidence that particular phenotypic classes or morphologies were linked to different environmental conditions. An external influence on phenotype might also be present in Hemihoplitidae as Bert (2012) reported that more robust individuals are usually found on the edges of the platform, while these morphotypes are rare in the pelagic environment. Similar environmental factors might also have played a role for the evolution of Gassendiceras towards more slender morphologies over time (Bert and Bersac 2013); both patterns have still have to be studied quantitatively.

We can extend environmental variation to geographic variation (Bert 2013), which is a scaled-up version of local and regional environmental differences that often remain undetected (Westermann 1996) given the limits of stratigraphic and 
Fig. 9.17 Differences in coiling (planispiral: white; trochospiral: black) within contemporary populations of Spiroceras orbignyi (Late Bajocian) depending on the locality/paleoenvironment (modified from Dietl 1978)

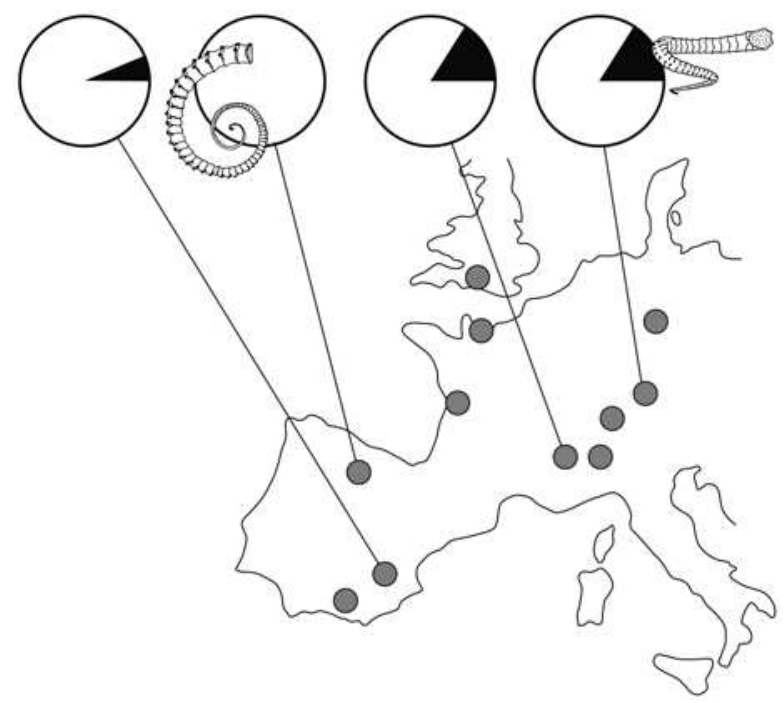

spatial resolution in temporally and/or spatially mixed fossil populations. Besides geographic differences in adult size (Sect. 9.7), authors have also reported geographic differences in shell shape (planispiral vs. trochospiral coiling: Dietl 1978; thickness ratio of shell whorls: Ikeda and Wani 2012; Yahada and Wani 2013) and ornamentation (e.g., differences in ribbing and furrows: Courville and Thierry 1993; Olóriz et al. 2000). Other shell shape parameters and the shape of the suture line might also be involved, but they have to our knowledge not yet been adequately studied. Some of these patterns might also be related to differences in growth rate and length of development, which have also been reported (e.g., Mignot et al. 1993; Reboulet 2001; Ploch 2007). Dietl (1978) noted a reduced variation in coiling (e.g., lack of three-dimensionally coiled or trochospiral forms) with increasing geographic distance from the "optimal biotope" (Fig. 9.17). He interpreted the high variation in shell shape in Spiroceras as an indication of a benthic mode of life on algal meadows (compare also Westermann 1996). Other authors have reported differences in whorl thickness ratios of shells (whorl breadth/shell diameter) between different areas and/or paleoenvironments, both in the Jurassic (e.g., Tintant 1963, 1980) and Cretaceous (Ploch 2007; Ikeda and Wani 2012; Yahada and Wani 2013). Tintant (1963) described differences in whorl height and umbilical width at the same diameters between different samples of Kepplerites gowerianus deriving from different localities, but the same subzone. Tintant (1980) stated this pattern could potentially be related to geographic variation, but might equally reflect a slightly different age of these samples, as Kepplerites shows similar changes in umbilical width and whorl height over evolutionary time. Ploch (2007) wrote that the specimens of Saynoceras verrucosum from the Vocontian Basin are more inflated (e.g., showed relatively larger whorl height than whorl width) than specimens from the Polish Basin. Some authors have attributed differences in certain characters such as whorl thickness ratios of shells between areas and/or paleoenvironments (Ikeda 
and Wani 2012; Yahada and Wani 2013) as an indication that members of different populations did not frequently migrate between these two areas in later ontogeny. Interestingly, the early ontogeny was indistinguishable in these specimens as these differences only developed later in ontogeny (compare Ikeda and Wani 2012; Yahada and Wani 2013). Inherent problems with temporal resolution in fossil populations (even within taxa deriving from the same biostratigraphic unit) hamper the separation of evolutionary changes (microevolution: compare Bert 2013) over time from geographic variation at the same time within species and lineages, particularly in the case of high intraspecific variability (compare Kennedy and Cobban 1976; Tintant 1980; Landman et al. 2008).

Not only the mode of intraspecific variation might change, but also the range of intraspecific variation can vary through time and/or space. Bert (2004) reported, for example, that the range of variation within species of Gregoryceras increases from the Cordatum Subzone (Lower Oxfordian, Jurassic) to reach its maximum in the Luciaeformis Subzone (Middle Oxfordian) and decreases thereafter. In the Cretaceous ammonoid Deshayesites fissicostatus, the proportion of smoother shells was reported by Bersac and Bert (2012a) to vary between the Fissicostatus and Obsoletus subzones (Lower Aptian) in southern England (Casey 1963), probably for local ecological reasons. Monnet et al. (2012) also reported similar irregular fluctuations through time in the range of intraspecific variation for the Triassic Acrochordiceras that are not clearly related to sample size or facies changes. Wiese and Schulze (2005) reported that local/regional populations of Neolobites vibrayeanus were apparently morphologically stable, but that little morphological overlap occurred between individuals of geographically separated assemblages.

High levels of morphological variability within a species have been attributed to various ecological and developmental mechanisms, including selection for ecological generalists in an unstable environment (Simpson 1944; Levins 1968), inherent developmental plasticity (West-Eberhard 2003, 2005), and the absence of competitors in an empty ecosystem (Westermann 1966, 1996). Yacobucci (2004b) investigated the response of Cretaceous Neogastroplites, known for its notorious range of intraspecific variation in shell shape and ornamentation (Reeside and Cobban 1960), to the invasion of a potential competitor, Metengonoceras, in the Mowry Sea. A competitive interaction model would predict that a variable species would contract its variation when encountering a new competitor. However, Neogastroplites responded not by decreasing its morphological variation but by expanding into a previously unoccupied region of its morphospace. Yacobucci (2004b) attributed the variability of Neogastroplites to environmental instability or developmental flexibility. Tanabe and Shigeta (1987) explained differences in the range of variation of shell shape, from high in heavily ornamented and heteromorph forms, to intermediate in finely ribbed platycone forms, to small in weakly ornamented forms, to possible differences in the mode of life of these ammonoids (see also Westermann 1996; Naglik et al. 2015). In some time intervals like the Triassic (e.g., Dagys and Weitschat 1993a, b; Dagys et al. 1999; Dagys 2001; Weitschat 2008), extreme intraspecific variation appears to have been particularly concentrated in high-latitude "polar" regions (a phenomenon also seen in extant gastropods: Clarke 1978). 
However, similar cases are known from more or less contemporary faunas from lower latitudes (Monnet et al. 2010) suggesting this interpretation might represent a preservational or collection bias. Geographic differences in size within species have often been attributed to the differences in environmental or geographic context (Mignot 1993; Mignot et al. 1993; Reboulet 2001; Ploch 2007). There also seems to be no clear link to endemism as a high range of intraspecific morphological variation is known not only from more endemic taxa (Thomasites: Courville and Thierry 1993) but also from more widespread, globally distributed taxa (Acrochordiceras: Monnet et al. 2010). Both phenomena still need to be studied more extensively and consistently.

\subsection{Quantification, Analysis and Comparison of Intraspecific Variation}

One must first quantify the degree and nature of the variation (by making measurements, calculating variance/standard deviation/coefficient of variation, making histograms that show the spread of the data, etc.) and then one can analyze the variation (e.g., looking for correlations among traits, tracking changes in variation through time and across space, etc.). Fundamentally, three types of quantitative methods are available to study intraspecific variation: univariate, bivariate and multivariate methods (e.g., Charpy and Thierry 1976; Bert 2013). Univariate methods (e.g., histograms, descriptive statistics) are typically employed to visualize and test the homogeneity of a sample restricted in time and/or space (Tintant 1980), but can also be used to test or plot intraspecific variation through ontogeny for various ontogenetic stages or size classes. Bivariate methods can be applied to test correlations between parameters and see changes in particular characters through ontogeny (De Baets et al. 2013a). Multivariate methods are commonly used to investigate the relative contribution of each measured character to the total variation of the sample and to group individuals by morphological or ontogenetic similarities considering all measured characters simultaneously (Charpy and Thierry 1976; Bert 2013).

\subsubsection{Univariate and Bivariate Methods}

Intraspecific variation of a single measurable character is often simply visualized by using a box-and-whisker plot for certain size classes or ontogenetic stages (e.g., Korn and Klug 2007; Monnet et al. 2010; Fig. 9.10, 9.18). However, such graphs do not show whether the specimens show a uni-, bi-, or multimodal distribution. As explained above, one might intuitively expect a unimodal distribution if the specimens belong to the same taxon with continuous variation (e.g., Monnet et al. 2010), whereas discontinuous variation or polymorphism might result in multimodality for certain characters. A particular case might be sexual dimorphism, where bimodality at the end of ontogeny can be expected (e.g., Palframan 1966, 1967). 

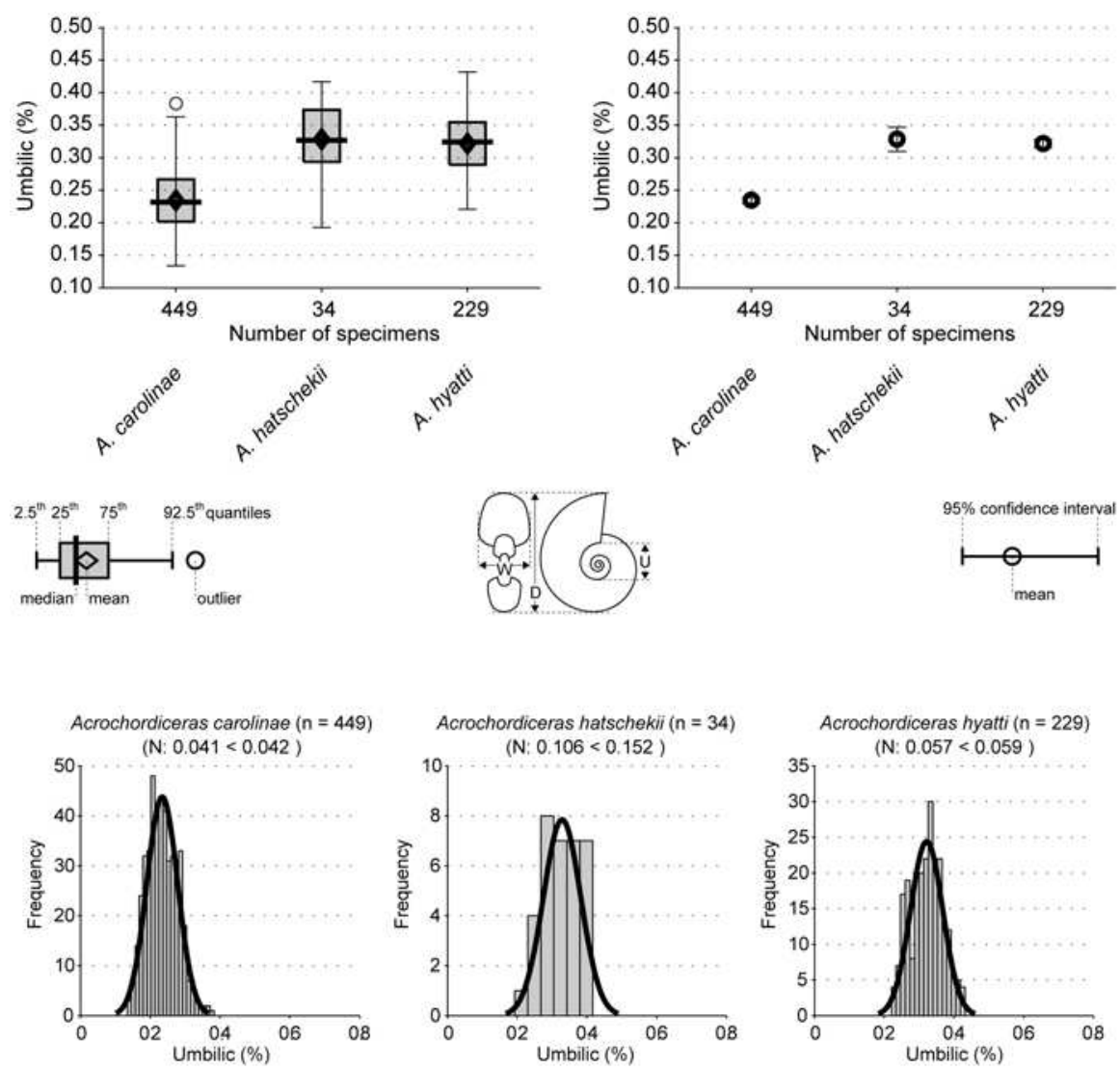

Fig. 9.18 Univariate tools used to study the range and distribution of intraspecific variation of the umbilical width with three species of Acrochordiceras (Middle Triassic; modified from Monnet et al. 2010): boxplots (upper left) and confidence intervals on the mean (upper right), which give only limited information on the density distribution of the data; histograms (bottom) illustrating the density distribution of intraspecific variation; note that not all specimens pass the normality test

Frequency distributions and (multi)modality of single traits are usually depicted with histograms, that is, a graphical representation of the data distribution that bins data into discrete intervals (Pearson 1895; Hammer and Harper 2006; Foote and Miller 2007; Fig. 9.18, 9.19). A histogram therefore only approximates the distribution of a variable (Pearson 1895). Histograms have certain disadvantages because they are discontinuous, have a fixed bin width, and are dependent on bin size and origin (Salgado-Ugarte et al. 2000). An alternative to the histogram is kernel density estimation, which uses a kernel to smooth samples. This approach will construct a smooth probability density function, which will in general more accurately reflect the underlying variable. In contrast to histograms, kernel density estimators are smoother and continuous, and allow for easier recognition of outliers, skewness, 

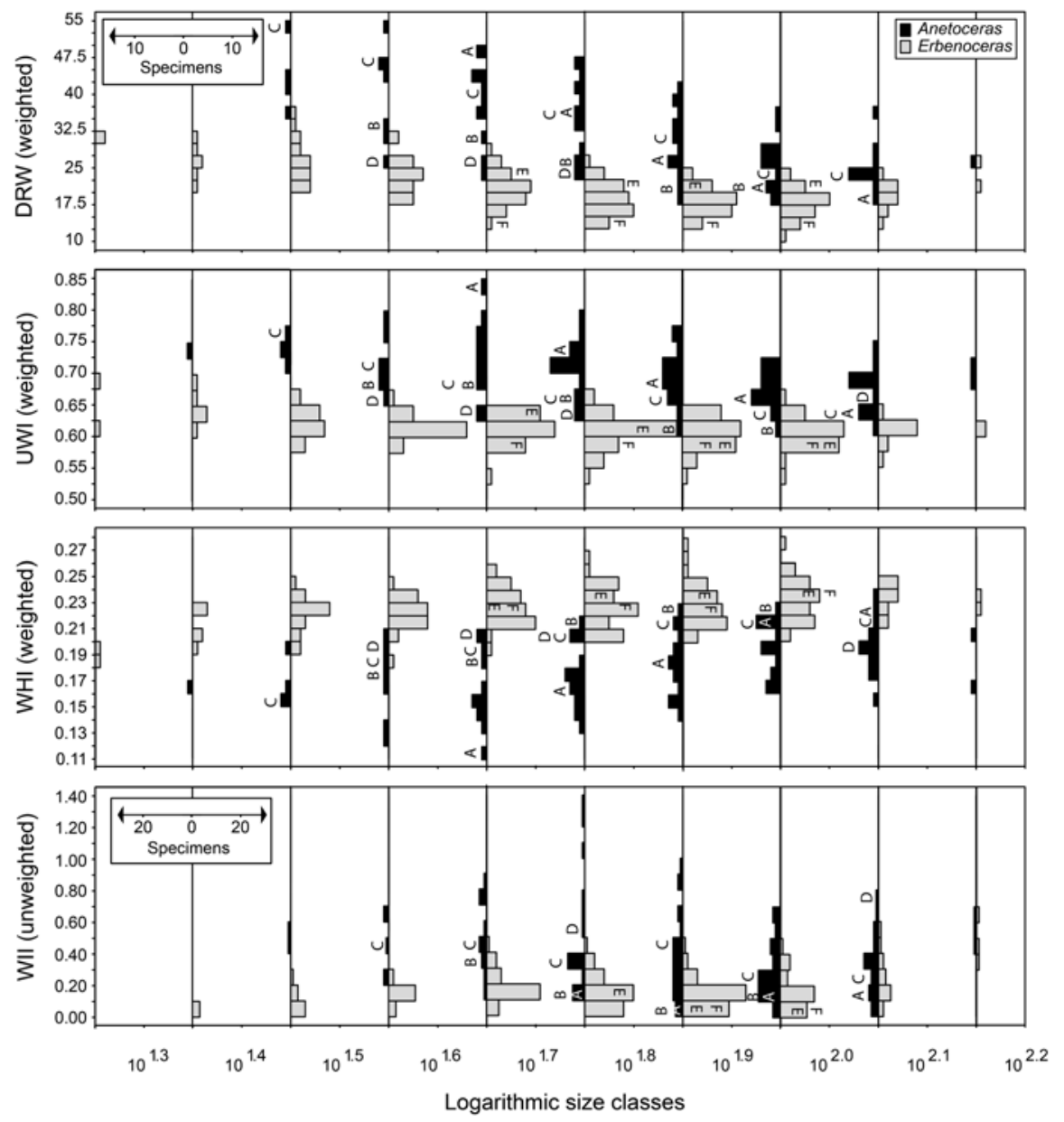

Fig. 9.19 Comparison of density distributions between two taxa using histograms over various size classes (modified from De Baets et al. 2013a)

and multimodality (Sanvicente-Añorve et al. 2003). A beanplot (Fig. 9.20, 9.21) is a combination of a 1-D scatterplot and a density trace (Kampstra 2008). In the 1-D scatterplot, each measurement is represented by a line, which makes it easy to spot outliers. If multiple measurements have the same value, the individual lines are added together increasing the length of the line. Beanplots also clearly show whether values are rounded or discontinuous. An alternative to the beanplot is the violin plot (Fig. 9.21), which is a combination of a box plot and a kernel density plot. It is probably best to investigate the frequency distribution and multimodality of ammonoid shell characters by combining several methods (Fig. 9.21).

Testing for a normal distribution is not only important to see if the sample is homogenous and that specimens might belong to the same species, but also for further 

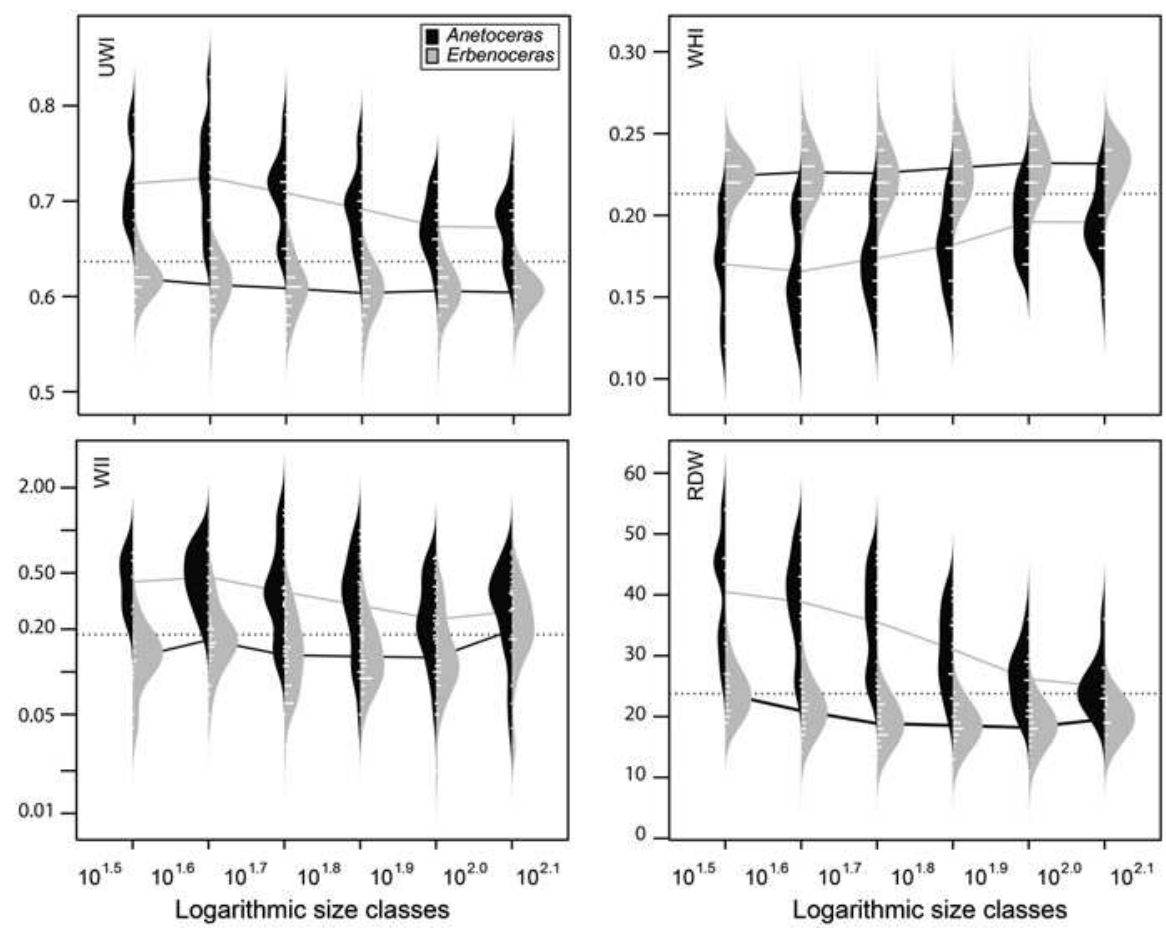

Fig. 9.20 Comparison of density distributions between two taxa using beanplots over various size classes. Note the unimodal distribution of the group in grey, while the second group shows a polymodal distribution, which might be due to a low sample size (modified from De Baets et al. 2013a)

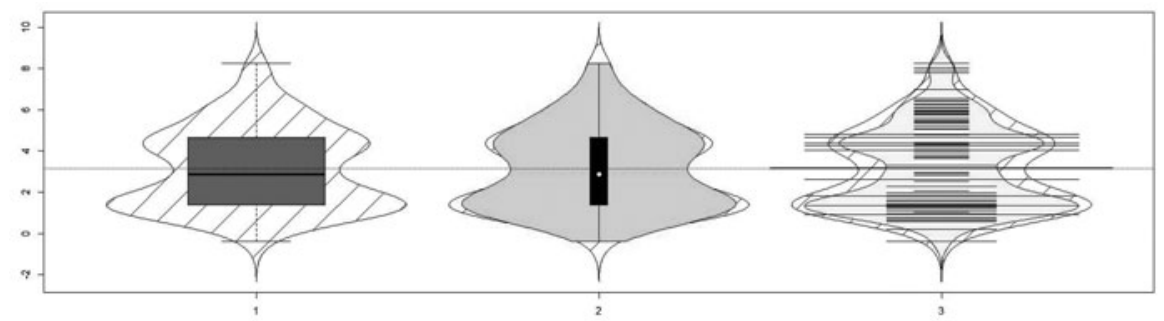

Fig. 9.21 Comparisons of a bimodal distribution using a boxplot (density distribution in the back for comparison), violin plot and beanplots (all graphs produced with $\mathrm{R}$ using packages UsingR, Vioplot and Beanplot)

statistical analyses as many (parametric) statistical tests assume a normal distribution (e.g., Hammer and Harper 2006; Monnet et al. 2010). Distribution-free or nonparametric statistical methods exist, but they often have a lower statistical power than parametric ones (Hammer and Harper 2006). For the purposes of analysis, a normal distribution can also be achieved by conducting various transformations of the raw data (e.g., Bert 2013). Although normal distribution determines the types of 
statistical methods that can be applied to the data and is expected for "biological" species, ammonoid species often deviate from normality "simply" by allometric changes and/or adult morphological changes (see e.g., Monnet and Bucher 2005; Fig. 9.18) and it is therefore not a strict prerequisite.

Bivariate methods are useful to test correlations between two parameters or to see changes in particular characters during growth by plotting the character against the diameter or another measure (e.g., De Baets et al. 2013a; Bert 2013; Fig. 9.9). Linear relationships between two parameters can be tested with a Pearson correlation coefficient (Pearson 1901) and non-linear monotonic correlations with a Spearman rank correlation coefficient (Spearman 1904; compare Sprent 1989). The relationship between two parameters can also be evaluated by fitting a model to the data. The model is often linear (e.g., Type I regression, reduced major axis regression) but need not be; for instance, exponential and logarithmic models may be more biologically appropriate. Analysis of residuals (that is, deviations from the fitted model) can reveal changes in the degree of variation that exists at different shell sizes.

\subsubsection{Multivariate Methods}

Often with ammonoids several different measurements are taken from one specimen and to study the collected data simultaneously requires multivariate methods. With the increasing power of computer processors that allows analysis of very large datasets, multivariate statistics have become indispensable analytical tools in paleontology. Multivariate techniques can be considered as an extension of univariate and bivariate techniques into multidimensional space, and many univariate and bivariate tests have multivariate analogs (Hammer and Harper 2006). The purpose of many multivariate approaches is similar to that of uni- and bivariate ones, involving the description and comparison of samples. However, multivariate data analysis can also be used for the exploration and visualization of complex data.

Many workers have used multivariate techniques to analyze morphometric data in ammonoids (e.g., Thierry 1978; Reyment and Kennedy 1991, 1998, 2000; Kassab and Hamama 1991; Hohenegger and Tatzreiter 1992; Reyment and Minaka 2000; Reyment 2003, 2004, 2011; Kennedy et al. 2009; Bert 2013; see Hammer and Harper 2006 for a more general review). Some of these methods have helped to discriminate species in ammonoids, to investigate overlap of morphological variants and intraspecific variation (including dimorphism) in specimens from a single locality and stratigraphic interval, or to understand how the morphological diversity of a sample is structured and how it is located with respect to other samples (e.g. factorial planes; the concept of morphological space of Neige et al. 1997b). It is also possible to avoid bias due to taxonomic classifications and analyze shape disparity among specimens directly (morphodiversity), through the use of shape parameters or landmarks (geometric morphometric analysis: see e.g., Neige and Dommergues 1995; Reyment and Kennedy 1991, 1998). For ammonoids, Saunders 
and Swan 1984 as well as Swan and Saunders 1987 performed some of the earliest morphospace analyses using ordination techniques (although these have sometimes been criticized: see Reyment and Kennedy 1991). Multivariate analysis can be a powerful tool for interpreting shape changes in terms of variability, evolution or paleoecology.

Using multivariate methods does require selecting appropriate data transformations and standardizations (Kenkel 2006). An appropriate multivariate analytical strategy should take into account the statistical relevance, data structure and the objectives of the study. Therefore, before proceeding with a formal multivariate analysis, it is important to complete a detailed exploratory analysis of the data (e.g. univariate and bivariate analysis).

Many multivariate analyses are rooted in ordination techniques. Ordination reduces a multivariate dataset to fewer, uncorrelated axes that capture most of the variation contained in the original data (Hammer and Harper 2006; Kenkel 2006). The ordination results can then be used to assess the relative contribution of each variable to each axis and to the overall variance structure of the data. In other terms, ordination gives an image (a morphological map) of the total measured variation of a sample, depending on the characters selected, and gives a summative model of the underlying data structure, by means of a projection of a point cloud of $n$-dimensional space onto a biplot (e.g., two-dimensional space defined by the first two ordination axes). Ordination methods actually used in biology are derived from Pearson's Factorial Analysis (Pearson 1901). The classical Principal Components Analysis (PCA, see Jolliffe 2002 for a review; compare Bert 2013) is one of the multivariate ordination methods most often applied to ammonoids (e.g., Reyment and Kennedy 1991; Kassab and Hamama 1991; Reyment and Minaka 2000; Reyment 2004; Bert 2013). Its purpose is to describe the total variance of a sample with the smallest possible number of factors, taking into account all the variables. Therefore, the PCA identifies the axes of maximum variance (the principal components, PC) in order to preserve as much variance as possible through the data compression process. With measurement data, the first axis (PC1), which contains the largest portion of the overall variation in the data, is typically interpreted as capturing variation in size, while the other axes express variation in shape (Hammer and Harper 2006). The specimens can then be projected onto a biplot, typically of PC1 vs. PC2, PC1 vs. $\mathrm{PC} 3$ or PC2 vs. PC3, with a minimum of distortion, so that two individuals that are similar morphologically will fall close to each other in the projected point cloud. The convex hulls (i.e., the limits of the point cloud) produced correspond to the occupation of the morphological space of the sample.

Disparity between several samples (or individuals) can be tested using analysis of similarity methods (one-way ANOSIM, MANOVA, etc: compare Hammer and Harper 2006; Bert 2013), which are based on comparing a measure of distance between groups with distances within groups. Here the homoscedasticity of the variable and the normal Gaussian distribution of the data (depending on the method) have to be tested. The results are given in a matrix of probability and graphically investigated also by ordination methods such as Canonical Variate Analysis (CVA: Ter Braak 1986; see Reyment 1998, 2003 for examples) or Discriminant Analysis 
(Fisher 1936; see Hohenegger and Tatzreiter 1992 for an example), which closely resembles PCA but produces factors (axes) that capture the maximum difference (instead of maximum variance for PCA) between predefined groups (e.g., species) and can help identify variables (characters), which contribute to these differences. These methods can be used, for example, to test for the presence of significant morphological differences between samples. Other methods are also available to isolate deviating specimens (ecomorphs) in a genetically homogeneous sample (compare Reyment 2004).

Despite their effectiveness, one of the main problems with multivariate analyses is that, as with most other statistical methods, they loose robustness with decreasing sample size. Hence, large samples are required as much as possible. This critical threshold is usually set to at least 32 specimens (see Tintant 1963; Bert 2013), which could be problematic when abundant and well-preserved material is scarce. When the sample is small, the risk is also high that the specimens studied do not represent the full range of variation of the whole population. This issue is however less problematic when the statistics are used only for a comparative and/or graphical purpose (Reyment and Kennedy 1991). Multivariate ordination methods also involve some loss of information, which in practice will likely not hamper the analysis. However, if the percentage of total variance explained by the first few ordination axes is low $(<70-90 \%$ depending on the analysis and the number of first "few" ordination axes retained for the analysis; see Joliffe 2002; Bert 2013), special caution is needed when analyzing the results. Another source of error lies with imperfections in the data, such as the inclusion of aberrant specimens or specimens with measurement errors that can produce misleading results. Such outliers have to be detected with other methods (e.g., a bivariate analysis is usually sufficient) and removed before the analysis. Problems with the data can also occur with the choice of the variables included into the analysis. Of particular concern is the inclusion of redundant characters. While it is impossible for all morphometric variables to be independent of each other (i.e., uncorrelated), if only because most measurements increase with size, efforts should be taken to minimize the redundancy of the variables so that certain aspects of shell form are not overemphasized in the resulting data set.

\subsubsection{Comparing the Range of Intraspecific Variation}

In order to understand and interpret morphological variation within ammonoid species, it is useful to quantify and compare the range of intraspecific variation among different samples or species. We will focus here on continuous variation (alternative methods are available for discrete variation that cannot be approximated by continuous distributions: Van Valen 2005). Extreme values (e.g., minima and maxima) are very sensitive to sample size, as is the total range of variation, so these metrics should be avoided in most cases unless sample sizes are high. The robustness of extreme values can be assessed by bootstrapping under conditions of different sampling densities (Monnet et al. 2010). The variance and its square root, the standard deviation, are most suitable for comparing intraspecific variation in single variables. 


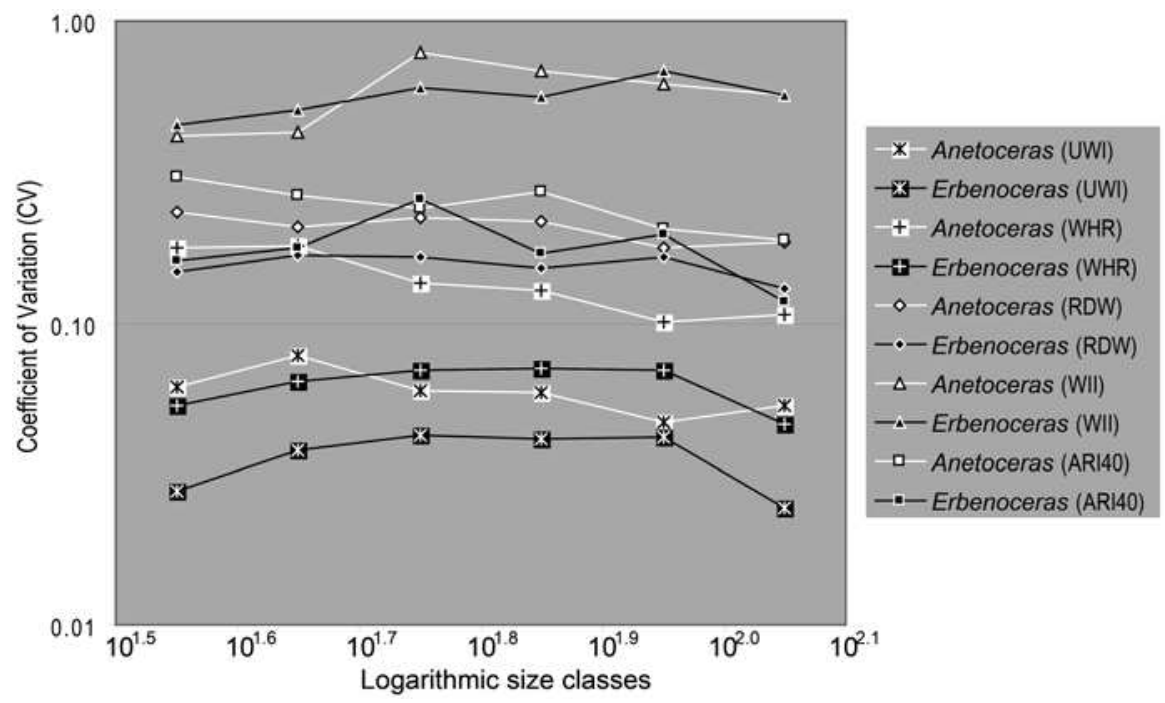

Fig. 9.22 Comparisons of the coefficient of variation of various characters between six ontogenetic (size) classes and two taxa (Anetoceras obliquecostatum and Erbenoceras solitarium, Early Devonian (modified from De Baets et al. 2013a)

The standard deviation is usually divided by the mean or "normalized" to obtain the coefficient of variation (CV). The coefficient of variation is a relative measure and should always be used "when the mean differs enough to matter" (Van Valen 2005). The CV is commonly used to compare the range of variation in ammonoids (e.g., Neige 1997; Parent 1998; Rouget and Neige 2001; Joly 2003; Tanabe et al. 2003; Yacobucci 2004a; De Baets et al. 2013a). It has the advantage that the range of variation of different characters and taxa can be directly compared with one another (e.g., De Baets et al. 2013a; Fig. 9.22). It can also be generalized for multivariate cases (Van Valen 1978, 2005). Van Valen (2005) reviewed the statistics of variation and suggested Levene's test (Levene 1960), Smith's Test (published in Grüneberg et al. 1966) and jackknifing (Arvesen and Schmitz 1970; Miller 1974; Bissell and Ferguson 1975), which can be used to compare absolute and relative variation, to be most suitable, depending on the situation (Van Valen 1978, 2005). He advised against using the classical F-test for the equality of variances as it is very sensitive to non-normality (Van Valen 2005).

A problem related to the pronounced variation seen in ammonoids is that successive faunas separated in time or contemporary faunas separated in space can only be compared on the basis of the mode and range of intraspecific variation within populations (Reeside and Cobban 1960; Kennedy and Cobban 1976; Dagys 2001; De Baets et al. 2013a; Fig. 9.23). This might also lead to small samples of intergrading populations, which can be considered to belong to different taxa, obscuring the synchronicity and identity of faunas (Kennedy and Cobban 1976). When only one specimen is available, it makes no sense to test if the mean of this population differs significantly from that of another population. Some approximate this by testing if 


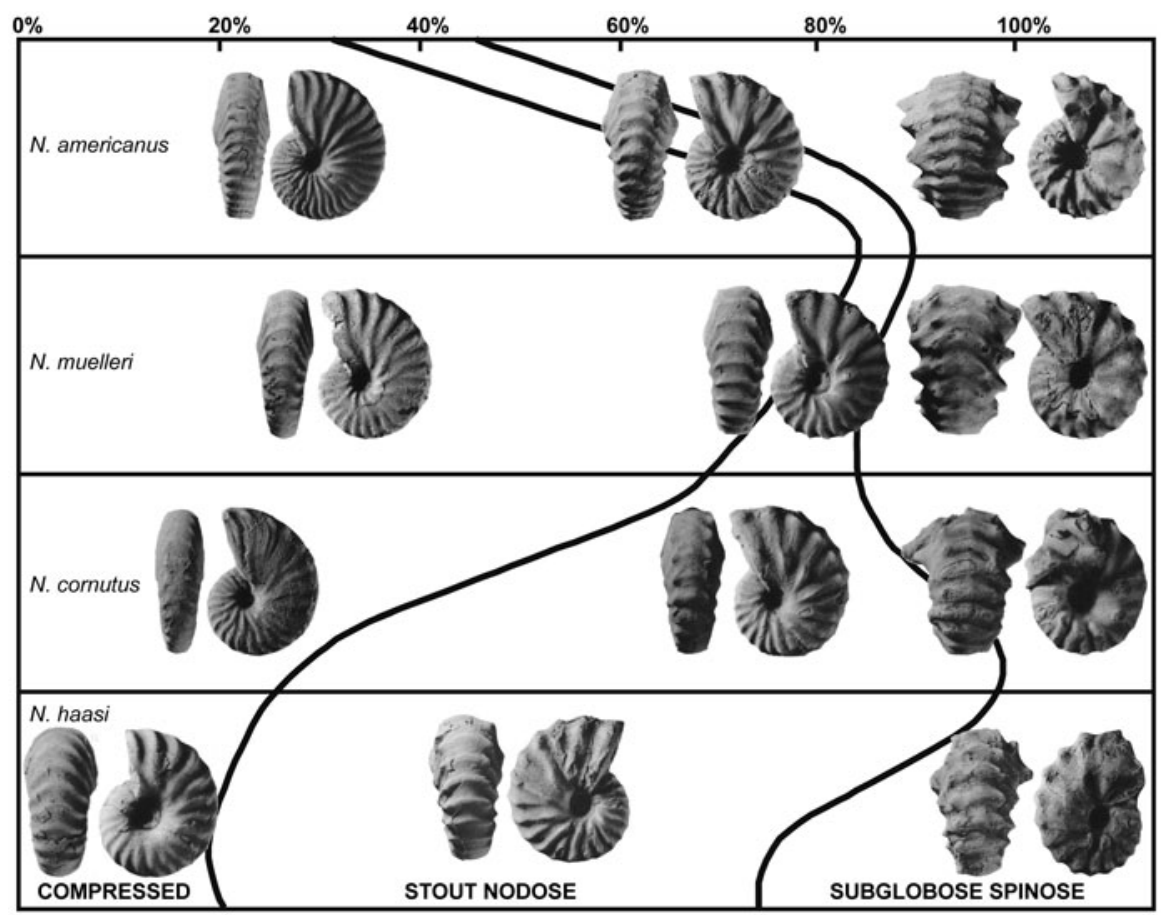

Fig. 9.23 Intraspecific variation and relative proportion of forms within four successive species of the Early Cenomanian hoplitid ammonoid Neogastroplites (modified from Kennedy and Cobban 1976: with permission from the authors). As first documented by Reeside and Cobban (1960), specimens recovered from single concretions within the Mowry Shale of the American Western Interior show extreme variation in shell shape and ornamentation. Reeside and Cobban (1960) subdivided this continuum of variation into three morphs, whose relative proportions vary from species to species. Sample sizes per concretion used to calculate percentages: $N$. haasi, $N=333 ; N$. cornutus, $N=2471 ; N$. muelleri, $N=3708 ; N$. americanus, $N=1286$. Specimen photos from Reeside and Cobban (1960): N. haasi from USGS Mesozoic Locality 24566: compressed, USNM 129308 (Plate 11, Fig. 4, 6); stout nodose, AMNH 28098:11 (Plate 13, Fig. 14, 15); subglobose spinose, AMNH 28095:25 (Plate 15, Fig. 12, 15). N. cornutus from USGS Mesozoic Locality 23021: compressed, USNM 129320a (Plate 5, Fig. 1, 2); stout nodose, USNM 129320f (Plate 5, Fig. 16, 17); subglobose spinose, USNM 129320n (Plate 5, Fig. 40, 41). N. muelleri from USGS Mesozoic Locality 24065: com-pressed, USNM 129416f(Plate 6, Fig. 16, 17); stout nodose, USNM 129416j (Plate 6, Fig. 28, 29); subglobose spinose, USNM 129416q (Plate 6, Fig. 49, 50). N. americanus from USGS Mesozoic Locality 23042: compressed, USNM 129528a (Plate 7, Fig. 1, 2); stout nodose, USNM 129528f (Plate 7, Fig. 16, 17); subglobose spinose, USNM 1295281 (Plate 7, Fig. 34,35 )

the measurement falls in the $95 \%$ range of that of the other population, which is actually a different question, or by assuming that the variance of one population is similar to that of the other, in which case the problem is reduced to comparing the means of both populations (Van Valen 2005). To accurately capture this variation, a sufficient number of specimens (>32: Tintant 1963, Bert 2013) needs to be collected from an interval restricted in time and space, which might also depend on 
the amount of variation observed within the population. If intraspecific variation is studied through ontogeny, a sufficient number of specimens needs to be available for each ontogenetic stage or size class that shall be used (De Baets et al. 2013a; Fig. 9.20, 9.22), which might mean a prohibitively large sample is required.

\subsection{Conclusions and Future Perspectives}

Intraspecific variation in shell shape, ornamentation, size and suture line is quite common in ammonoids and can in some cases be larger within a single fossil assemblage than differences in morphology over space and/or time within these lineages. Some authors, like Lehmann (1990, p. 23), have stated that intraspecific variation in ammonoids does not follow general laws or rules, but it is evident from our review that many ammonoid workers agree that at least some generalizations or recurrent patterns can be recognized. Nevertheless, the type and degree of intraspecific variation can be highly different from taxon to taxon, which is not unexpected considering the large differences in shell shape of ammonoids and intraspecific variation in extant cephalopods. Two main types of intraspecific variation are commonly recognized, which are not necessarily mutually exclusive:

- Continuous intraspecific variation in shell shape, ornamentation, suture line and size and

- Discontinuous intraspecific variation in the above mentioned aspects (dimorphism and polymorphisms).

Continuous intraspecific variation has mainly been studied from the perspective of covariation between shell shape, ornamentation and more rarely studied more often lines as well as the perspective of variation in ontogenetic development. The few studies using a large amount of material and employing quantitative methods have particularly focused on Mesozoic coiled ammonoids showing extensive ranges of intraspecific variation (e.g., Reeside and Cobban 1960, Dagys and Weitschat 1993b; Checa et al. 1996; Morard and Guex 2003; Weitschat 2008; Monnet et al. 2010), but a large range of intraspecific variation also seems to be present in at least some Paleozoic taxa (e.g., Klug and Korn 2007; De Baets et al. 2013a) and Mesozoic heteromorph ammonoids (e.g., Bert 2013; Knauss and Yacobucci 2014).

The presence of discrete morphologies within a species in the form of intraspecific sexual dimorphism and non-sexual polymorphism has been suggested based on polymodal distributions in shell shape, ornamentation and/or size in late and/or early ontogeny in contemporary specimens. Nevertheless, studies show that the paleoenvironment (Wilmsen and Mosavinia 2011), taphonomic biases (Tintant 1980) and undersampling (De Baets et al. 2013a) can also lead to polymodal density distributions in forms of the same age and region with continuous intraspecific variation.

Heritable (genetic) variation is the raw material for evolution, but a larger part of the intraspecific variation seen in ammonoids might be related to differences in growth rates and ontogenetic trajectories (Urdy et al. 2010a, b). The large in- 
traspecific variation documented in many ammonoids might have had a partially intrinsic component, but a large part might be linked with the interplay between developmental and environmental parameters. This is corroborated by the range of intraspecific variation in size and shell morphology observed at the same localities and between different paleoenvironments and regions. The large range of intraspecific variation within and between ammonoid populations has typically led to an artificial inflation of diversity (oversplitting) by using strict typological approaches. But mixing together specimens from different regions and ages (analytical timeaveraging) can also lead to an artificial deflation of diversity (lumping). Intraspecific variability is often not properly taken into account or quantitatively analyzed, which is detrimental not only to systematic and evolutionary studies, but also to biostratigraphic, biogeographic and diversity studies.

Intraspecific variability in Paleozoic and heteromorph taxa as well as Mesozoic coiled taxa showing little intraspecific variation should be quantitatively studied more often to better understand the type and range of intraspecific variation as well as possible relations with shell morphology. Previous studies can also be further refined when more material, more ontogenetic stages or a finer stratigraphic framework becomes available. Various statistical methods are available and easily accessible through free software (PAST: Hammer et al. 2001; The R Project for Statistical Computing: http://www.r-project.org/), which makes it possible to analyze interpopulation and intrapopulation variation within ammonoid species quantitatively. New approaches to quantifying morphological variation that are rooted in spatial statistics can also be applied to many ammonoid groups (Manship 2004, 2008; Yacobucci and Manship 2011; Knauss and Yacobucci 2014). A better understanding of the types and drivers of intraspecific variation in ammonoids can only be achieved by quantitative analyses of numerically large samples from a wide variety of ages, paleoenvironments, geographic areas, taxa and shell morphologies.

Acknowledgments Some of the insights described in this chapter grew during the course of research projects 200021-1139561, 200020-25029, and 200020-132870 funded by the Swiss National Science Foundation SNF. David Ware (Zürich) and Isabelle Rouget (Paris) helped with obtaining some of the literature. Markus Wilmsen (Senckenberg Natural History Collections, Dresden), Gene Hunt (Smithsonian Institution, Washington, USA) and Michał Zatoń (University of Silesia, Sosnowiec) kindly put figures at our disposal. Jerzy Dzik (Institute of Paleobiology, Polish Academy of Sciences, Warsaw), Helga Weitschat on behalf of Wolfgang Weitschat (Geological-Paleontological Institute and Museum, University of Hamburg, retired), Vasily Mitta (Paleontological Institute, Russian Academy of Sciences, Moscow), Lionel Cavin (Natural History Museum of Geneva) on behalf of the journal Revue de Paléobiologie, and Jim Kennedy (University of Oxford, retired) gave permission to use their figures. We thank the reviewers Michał Zatoń (University of Silesia, Sosnowiec) and Sonny A. Walton (Naturkunde Museum, Berlin) for the constructive comments and suggestions. We would like to dedicate this chapter to the inspiring work of Algirdas Dagys and Wolfgang Weitschat on intraspecific variation in Triassic ammonoids. 


\section{References}

Adams DC, Collyer ML (2009) A general framework for the analysis of phenotypic trajectories in evolutionary studies. Evolution Int J org Evolution 63:1143-1154

Ager DV (1963) Principles of paleoecology. McGraw Hill, New York

Aguirre-Urreta MB (1998) The ammonites Karakaschiceras and Neohoploceras (Valanginian Neocomitidae) from the Neuquen basin, west-central Argentina. J Paleontol 72:39-59

Aguirre-Urreta MB, Riccardi AC (1988) Albian heteromorph ammonoids from southern Patagonia, Argentina. J Paleontol 62:598-614

Andrew C, Howe P, Paul CRC, Donovan SK (2011) Epifaunal worm tubes on Lower Jurassic (Lower Lias) ammonites from Dorset. Proc Geol Assoc 122:34-46

Arkell WJ (1957) Introduction to Mesozoic Ammonoidea. In: Moore RC (ed) Treatise on invertebrate paleontology, Part L, Mollusca 4, Cephalopoda-Ammonoidea. GSA and University of Kansas Press, L80-L100

Arkhipkin A (1992) Reproductive system structure, development and function in cephalopods with a new general scale for maturity stages. J Northw Atl Fish Sci 12:63-74

Arkhipkin AI (2004) Diversity in growth and longevity in short-lived animals: squid of the suborder Oegopsina. Mar Freshw Res 55:341-355

Arkhipkin A, Laptikhovsky V (1994) Seasonal and interannual variability in growth and maturation of winter-spawning Illex argentinus (Cephalopoda, Ommastrephidae) in the Southwest Atlantic. Aquat Living Resour 7:221-232

Arvesen JN, Schmitz TH (1970) Robust procedures for variance component problems using the jackknife. Biometrics 26:677-686

Atrops F, Mélendez G (1993) Current trends in systematics of Jurassic Ammonoidea: the case of Oxfordian-Kimmeridgian perisphinctids from southern Europe. Geobios 26(Suppl 1):19-31. doi:http://dx.doi.org/10.1016/S0016-6995(06)80357-8

Aubrecht R, Schlögl J (2011) Jurassic submarine troglobites: is there any link to the recent submarine cave fauna? Hydrobiologia 677:3-14

Bailey RC, Byrnes J (1990) A new, old method for assessing measurement error in both univariate and multivariate morphometric studies. Syst Biol 39:124-130

Barber WM (1957) The Lower Turonian ammonites of northeastern Nigeria. Bull Geol Surv Nigeria $26: 1-86$

Bardhan S, Jana SK, Datta K (1993) Preserved color pattern of a phylloceratid ammonoid from the Jurassic Chari Formation, Kutch, India, and its functional significance. J Paleontol 67:140-143

Bardhan S, Jana SK, Roy P (2010) Sexual dimorphism and polymorphism in a Callovian Phlycticeras (Ammonoidea) assemblage of Kutch, India. Geobios 43:269-281

Baudouin C, Boselli P, Bert D (2011) The Oppeliidae of the Acanthicum zone (Upper Kimmeridgian) from Mount Crussol (Ardèche, France): ontogeny, variability and dimorphism of the genera Taramelliceras and Streblites (Ammonoidea). Rev Paleobiol 30:619-684

Baudouin C, Bert D, Boselli P (2012) Preview on the ontogeny, variability and dimorphism of the genera Taramelliceras and Streblites (Ammonoidea) of the Acanthicum zone (Upper Kimmeridgian) from Mount Crussol (Ardèche, France). Bol Inst Fisiog Geol 82:19-21

Bayer U, McGhee GR Jr (1984) Iterative evolution of middle Jurassic ammonite faunas. Lethaia 17:1-16

Bayer U, McGhee GR Jr (1985) Evolution in marginal epicontinental basins: the role of phylogenetic and ecological factors. Ammonite replacements in the German Lower and Middle Jurassic. In: Bayer U, Seilacher A (eds) Sedimentary and evolutionary cycles. Springer, Berlin

Bert D (2004) Révision, etude systématique et evolution du genre Gregoryceras Spath, 1924 (Ammonoidea, Oxfordien). Ann Mus Hist Nat Nice 19:1-184

Bert D (2009) Discussion, evolution and new interpretation of the Tornquistes Lemoine, 1910 (Pachyceratidae, Ammonitina) with the exemple of the verte-brale subzone sample (Middle Oxfordian) of southeastern France. Rev Paleobiol 28:471-489 
Bert D (2012) Phylogenetic relationships among the Hemihoplitidae Spath 1924 (Ammonoidea, Upper Barremian). Boletin del Instituto de Fisiografia y. Geologia 82:17-18

Bert D (2013). Factors of intraspecific variability in ammonites, the example of Gassendiceras alpinum (d'Orbigny, 1850) (Hemihoplitidae, Upper Barremian). Annales de Paléontologie doi:10.1016/j.annpal.2013.11.007

Bersac S, Bert D (2012a) Ontogenesis, variability and evolution of the Lower Greensand Deshayesitidae (Ammonoidea, Lower Cretaceous, Southern England): reinterpretation of literature data; taxonomic and biostratigraphic implications. Ann Mus Hist Nat Nice 27:197-270

Bersac S, Bert D (2012b) Variability and evolution of the Deshayesitidae (Ammonoidea, Lower Aptian, Lower Cretaceous) from southern England. Bol Inst Fisiog Geol 82:27-30

Bert D, Bersac S (2013) Evolutionary patterns-tested with cladistics-and pro-cesses in relation to palaeoenvironments of the Upper Barremian genus Gassendiceras (Ammonitina, Lower Cretaceous). Palaeontology 56:631-646

Bert D, Delanoy G, Bersac S (2011) The dichotomus horizon: a new biochronologic unit of the Giraudi zone of the Upper Barremian of southeastern France, and considerations regarding the genus Imerites Rouchadze (Ammonoidea, Gassendiceratinae). Carnets Geol 2011/01: http:// paleopolis.rediris.es/cg/CG2011_A01/

Beznosov NV, Mitta VV (1995) Polymorphism in the Jurassic ammonoids. Paleontol J 29:46-57

Bhaumik D, Datta K, Jana-Sudipta K, Bardhan S (1993) Taxonomy and intraspecific variation of Macrocephalites formosus (Sowerby) from the Jurassic Chari Formation, Kutch, western India. J Geol Soc India 42:163-179

Bissell A, Ferguson R (1975) The jackknife-toy, tool or two-edged weapon? The Statistician:79-100

Blake JF (1878) On the measurements of curves formed by cephalopods and other mollusks. Philsoph Mag 5:241-262

Boletzky Sv (1974) Effets de la sous-nutrition prolongée sur le développement de la coquille de Sepia officinalis L. (Mollusca, Cephalopoda). Bull Soc Zool Fr 99:667-673

Boletzky Sv (2003) Biology of early life stages in cephalopod molluscs. Adv Mar Biol 44:143-203

Bonnot A, Marchand D, Neige $\mathrm{P}$ (1999) Les Oppeliidae (Ammonitina) de l'horizon à Collotiformis (Callovien supérieur, zone à Athleta) de la région Dijonnaise (Côte-d'Or, France). Annales de Paléontologie 85:241-263

Bookstein FL, Ward PD (2013) A modified procrustes analysis for bilaterally symmetrical outlines, with an application to microevolution in Baculites. Paleobiology 39:214-234

Boyle P, Ngoile M (1993) Population variation and growth in Loligo forbesi (Cephalopoda: Loliginidae) from Scottish waters. In: Okutani T, O'Dor RK, Kubodera T (eds) Recent advances in cephalopod fisheries biology. Tokai University Press, Tokyo

Boyle PR, von Boletzky S (1996) Cephalopod populations: definition and dynamics. Philos Trans R Soc B-Biol Sci 351(1343):985-1002. doi:10.2307/56291

Brayard A, Escarguel G (2013) Untangling phylogenetic, geometric and ornamental imprints on Early Triassic ammonoid biogeography: a similarity-distance decay study. Lethaia 46:19-33

Brayard A, Escarguel G, Bucher H, Monnet C, Brühwiler T, Goudemand N, Galfetti T, Guex J (2009) Good genes and good luck: ammonoid diversity and the end-permian mass extinction. Science 325:1118-1121

Brochwicz-Lewiński W, Rózak Z (1976) Some difficulties in recognition of sexual dimorphism in Jurassic perisphinctids (Ammonoidea). Acta Palaeontol Polonica 21:115-124

Bucher H (1997) Caractères périodiques etmode de croissance des ammonites: Comparaison avec les gastéropodes. Geobios 30(Suppl 1):85-99

Bucher H, Landman NH, Klofak SM, Guex J (1996) Mode and rate of growth in ammonoids. In: Landman NH, Tanabe K, Davis RA (eds) Ammonoid paleobiology. Plenum, New York

Buckman SS (1887-1907) A monograph of the ammonites of the inferior oolite series. Palaeontogr Soc 40-61:1-456

Bulmer MG (1980) The mathematical theory of quantitative genetics. Oxford Science Publications, Oxford 
Callomon JH (1963) Sexual dimorphism in Jurassic ammonites. Trans Leicester Lit Philos Soc $57: 21-56$

Callomon J (1985) The evolution of the Jurassic ammonite family Cardioceratidae. Spec Pap Palaeontol 33:49-90

Callomon JH (1988) Review of Matyja 1986. Cephalopod Newsletter 9:14-16

Casey R (1961) A monograph of the Ammonoidea of the Lower Greensand, part II. Palaeontogr Soc Lond 493:45-118

Casey R (1963) A monograph of the Ammonoidea of the Lower Greensand, part V. Palaeontogr Soc Lond 502:289-398

Chandler R, Callomon J (2009) The inferior oolite at Coombe quarry, near Mapperton, Dorset, and a new Middle Jurassic ammonite faunal horizon, Aa-3b, Leioceras comptocostosum $\mathrm{n}$. biosp. in the Scissum zone of the Lower Aalenian. Proc Dorset Nat Hist Archaeol Soc 130:99-132

Charpy N, Thierry J (1976) Dimorphisme et polymorphisme chez Pachyceras Bayle (Ammonitina, Stephanocerataceae) du Callovien Supérieur (Jurassique Moyen). Haliotis 6:185-218

Checa A, Company M, Sandoval J, Weitschat W (1996) Covariation of morpho-logical characters in the Triassic ammonoid Czekanowskites rieberi. Lethaia 29:225-235

Chlupáč I, Turek V (1983) Devonian goniatites from the Barrandian area. Rozpr Ustred Ust Geol 46:1-15

Clarke JM (1899) The Naples fauna (fauna with Manticoceras intumescens) in western New York. New York State Museum. Annu Rep Regents 50:31-161

Clarke AH (1978) Polymorphism in marine mollusks and biome development. Smithson Contrib Zool 274:1-14

Collyer ML, Adams DC (2013) Phenotypic trajectory analysis: comparison of shape change patterns in evolution and ecology. Hystrix 24:75-83

Contini D, Marchand D, Thierry J (1984) Reflexions sur la notion de genre et de sous-genre chez les Ammonites: exemples pris essentiellement dans le Jurassique moyen. Bull Soc Geol Fr 26:653-666

Courville P (1993) Les formations marines et les faunes d'ammonites cénomaniennes et turoniennes (Crétacé supérieur) dans le Fosséde la Bénoué (Nigéria). Impacts des facteurs locaux et globaux sur les échanges fauniques à l'interface Téthys/ Atlantique Sud. Unpubl PhD Thesis, Univ de Dijon, p. 360

Courville P (2011) Caractères ornementaux, disparité et diversité chez les Ammonitina: exemple des Kosmoceratinae (Stephanoceratoidea), Callovien moyen et supérieur (Jurassique moyen, Bassin parisien). C R Palevol 10:155-170

Courville P, Crônier C (2003) Les hétérochronies du développement: un outil pour l'étude de la variabilité et des relations phylétiques: Exemple de Nigericeras, Ammonitina du Crétacé supérieur africain. C R Palevol 2:535-546

Courville P, Crônier C (2005) Diversity or disparity in the Jurassic (Upper Callovian) Genus Kosmoceras (Ammonitina): a morphometric approach. J Paleontol 79:944-953

Courville P, Lebrun P (2010) L'Albien (Crétacé) de la region de Troyes (Aube) et ses ammonites: Hoplitidae et Douvilleiceratidae. Fossiles 4:4-30

Courville P, Thierry J (1993) Sous-espèces géographiques et/ou contrôle environnemental de la variabilité morphologique chez "Thomasites" gongilensis (Woods, 1911), (Ammonitina, Acanthocerataceae, Vascoceratinae) du Turonien inférieur de la Haute Bénoué (Nigéria). Geobios 26(Suppl 1):73-89

Crick RR (1978) Morphological variations in the ammonite Scaphites of the Blue Hill member, Crlile Shale, Upper Cretaceous. Univ Kans Paleontol Contrib 88:1-30

Dagys AS (2001) The ammonoid family Arctohungaritidae from the boreal Lower-Middle Anisian (Triassic) of arctic Asia. Rev Paleobiol 20:543-546

Dagys AS, Weitschat W (1993a) Intraspecific variation in Boreal Triassic ammonoids. Geobios 26:107-109

Dagys AS, Weitschat W (1993b) Extensive intraspecific variation in a Triassic ammonoid from Siberia. Lethaia 26:113-121 
Dagys AS, Bucher H, Weitschat W (1999) Intraspecific variation of Parasibirites kolymensis Bychkov (Ammonoidea) from the Lower Triassic (Spathian) of arctic Asia. Mitt aus dem GeolPaläont Inst Universität Hamburg 83:163-178

Darwin CR (1859) On the origin of species by means of natural selection, or the preservation of favoured races in the struggle for life. John Murray, London

Davis RA, Landman NH, Dommergues J-L, Marchand D, Bucher H (1996) Mature modifications and dimorphism in ammonoid cephalopods. In: Landman NH, Tanabe K, Davis RA (eds) Ammonoid paleobiology. Plenum, New York

De Baets K, Klug C, Monnet C (2013a) Intraspecific variability through ontogeny in early ammonoids. Paleobiology 39:75-94

De Baets K, Klug C, Korn D, Bartels C, Poschmann M (2013b) Emsian Ammonoidea and the age of the Hunsrück Slate (Rhenish Mountains, Western Germany). Palaeontogr A 299:1-113

De Baets K, Keupp H, Klug C (2015a) Parasites of ammonoids. This volume

De Baets K, Landman NH, Tanabe K (2015b) Ammonoid embryonic development. This volume

De Beer G (1958) Evolution by natural selection: a centenary commemorative volume. Papers by Charles Darwin and Alfred Wallace. Cambridge University, Cambridge

Delanoy G (1997) Biostratigraphie des faunes d'Ammonites à la limite Barrémien-Aptien dans la région d'Angles-Barrême-Castellane. Étude particulière de la Famille des Heteroceratidae Spath 1922 (Ancyloceratina, Ammonoidea). Ann Mus Hist Nat Nice 12:1-270

Delanoy G, Ropolo P, Magnin A, Autran G, Poupon A, Gonnet R (1995) Sur le dimorphisme chez les Ancyloceratina (Ammonoidea) du Crétacé Inférieur. C R Acad Sci Ser IIa 321:537-543

Dera G, Neige P, Dommergues J-L, Brayard A (2011) Ammonite paleobiogeography during the Pliensbachian-Toarcian crisis (Early Jurassic) reflecting paleoclimate, eustasy, and extinctions. Glob Planet Change 78:92-105

Diedrich C (2000) Faziesabhängige Schalenmorphologie des Großammoniten Puzosia dibleyi (Spath 1922) aus dem Puzosia-Event I (Ober-Cenoman) von Europa. Senckenb Lethaea 80:463-483

Dietl G (1978) Die heteromorphen Ammoniten des Dogger. Stuttg Beitr Natur B 33:1-97

Dietze V, Callomon JH, Schweigert G, Chandler RB (2005) The ammonite fauna and biostratigraphy of the Lower Bajocian (Ovale and Laeviuscula zones) of E Swabia (S Germany). Stuttg Beitr Natur B353:1-82

Doguzhaeva L (1982) Rhythms of ammonoid shell secretion. Lethaia 15:385-394

Dommergues J-L (1988) Can ribs and septa provide an alternative standard for age in ammonite ontogenetic studies? Lethaia 21:243-256

Dommergues J-L, David B, Marchand D (1986) Les rélations ontogenèse-phylogenèse: applications paléontologiques. Geobios 19:335-356

Dommergues J-L, Cariou E, Contini D, Hantzpergue P, Marchand D, Meister C, Thierry J (1989) Homéomorphies et canalisations évolutives: Le rôle de l'ontogenèse. Quelques exemples pris chez les Ammonites du Jurassique. Geobios 22:5-48

Dommergues J-L, Montuire S, Neige P (2002) Size patterns through time: the case of the early Jurassic ammonite radiation. Paleobiology 28:423-434

Dommergues E, Dommergues J-L, Dommergues C-H (2006) Deux espèces sous un même masque. Le point de vue paléontologique piégé par les coquilles de deux espèces européennes de Trivia (Mollusca, Gastropoda). Rev Paleobiol 25:775-790

Donovan DT (1994) History of classification of Mesozoic ammonites. J Geol Soc 151:1035-1040

Dzik J (1985) Typologic versus population concepts of chronospecies: implications for ammonite biostratigraphy. Acta Palaeontol Pol 30:71-92

Dzik J (1990a). The concept of chronospecies in ammonites. In: Cecca F, Cresta S, Pallini G, Santantonio M (eds) Atti del Secondo Convegno Inter-nazionale Fossili, Evoluzione, Ambiente, Pergola 25-30 ottobre 1987 estratto, Pergola, Comitato Centenario Raffaele Piccinini

Dzik J (1990b) The ammonite Acrochordiceras in the Triassic of Silesia. Acta Palaeontol Pol 35:49-65

Dzik J (1994) Sexual dimorphism in the virgatitid ammonites. Palaeopelagos Spec Publ 1:129-141 
Ebbighausen V, Korn D (2007) Conch geometry and ontogenetic trajectories in the triangularly coiled Late Devonian ammonoid Wocklumeria and related genera. Neues Jahrb Geol Paläontol Abh 244:9-41

Egojan VL (1969) Ammonites from the Clanseysian beds of the western Caucasus. Trud Krasnodar Fil Vses Neftegazov Nauchnoissledovatel'sk Inst 19:126-188 [in Russian]

Elmi S, Benshili K (1987) Relations entre la structuration tectonique, la composition des peuplements et l'évolution; exemple du Toarcien du Moyen-Atlas méridional (Maroc). Boll Soc Paleontol Ital 26:47-62

Erben HK (1950) Bemerkungen zu Anomalien mancher Anfangswindungen von Mimagoniatites fecundus (Barr.). Neues Jahrb Geol Paläont Mh:25-32

Erben HK (1964) Die Evolution der ältesten Ammonoidea (Lieferung I). Neues Jahrb Geol Paläontol Abh 120:107-212

Flessa KW, Kowalewski M (1994) Shell survival and time-averaging in nearshore and shelf environments: estimates from the radiocarbon literature. Lethaia 27:153-165

Fernández-López S (1995) Taphonomie et interpretation des paléoenvironements. Géobios 18:137-154

Fernández-López S (2000) Temas de Tafonomía. Departamento de Paleontología. Universidad Complutense de Madrid, Madrid

Fisher RA (1936) The use of multiple measurements in taxonomic problems. Ann Eugen 7:179188

Flessa KW, Cutler AH, Meldahl KH (1993) Time and taphonomy: quantitative estimates of timeaveraging and stratigraphic disorder in a shallow marine habitat. Paleobiology 19:266-286

Foote M, Miller AI (2007) Principles of paleontology. Freeman, New York

Ford EB (1940) Polymorphism and taxonomy. In: Huxley JS (ed) The new systematics. Oxford University, Oxford

Ford EB (1945) Polymorphism. Biol Rev 20:73-88

Ford EB (1955) Polymorphism and taxonomy. Heredity 9:255-264

Ford EB (1965) Genetic polymorphism. Faber and Faber, London

Ford EB (1966) Genetic polymorphism. Proc R Soc B-Biol Sci 164:350-361

Fürsich FT, Aberhan M (1990) Significance of time-averaging for palaeocommunity analysis. Lethaia 23:143-152

Furnish WM, Knapp WD (1966) Lower Pennsylvanian fauna from eastern Kentucky; Part 1, Ammonoids. J Paleontol 40:296-308

Fusco G, Minelli A (2010) Phenotypic plasticity in development and evolution: facts and concepts. Philos Trans R Soc B-Biol Sci 365:547-556

Gangopadhyay TK, Bardhan S (2007) Ornamental polymorphism in Placenticeras kaffrarium (Ammonoidea; Upper Cretaceous of India): evolutionary implications. In: Landman N, Davis R, Mapes R (eds) Cephalopods present and past: new insights and fresh perspectives. Springer, Netherlands

Göddertz B (1989) Unterdevonische hercynische Goniatiten aus Deutschland, Frankreich und der Türkei. Palaeontogr A 208:61-89

Goodfriend GA (1986) Variation in land-snail shell form and size and its causes: a review. Syst Biol 35:204-223

Grüneberg H, Bains GS, Berry BJ, Riles L, Smith C, Weiss R (1966) A search for genetic effects of high natural radioactivity in south India. Spec Rep Ser Med Res Counc 307:1-59

Guex J (2001) Environmental stress and atavism in ammonoid evolution. Eclogae Geol Helv 94:321-328

Guex J (2003) A generalization of Cope's rule. Bull Soc Geol Fr 174:449-452

Guex J, Koch A, O’Dogherty L, Bucher H (2003) A morphogenetic explanation of Buckman's law of covariation. Bull Soc Geol Fr 174:603-606

Haas O (1946) Intraspecific variation in, and ontogeny of, Prionotropis woollgari and Prionocyclus wyomingensis. Bull Am Mus Nat Hist 86(4):141-224

Hallam A (1965) Environmental causes of stunting in living and fossil marine benthonic invertebrates. Palaeontology 8:132-155 
Hallgrímsson B, Hall BK (2005) Variation: a central concept in biology. Elsevier, Amsterdam

Hammer Ø, Bucher H (2005) Buckman's first law covariation-a case of proportionality. Lethaia 38:67-72

Hammer Ø, Harper DAT (2006) Paleontological data analysis. Wiley-Blackwell, United Kingdom

Hammer Ø, Bucher H (2006) Generalized ammonoid hydrostatics modelling, with application to Intornites and intraspecific variation in Amaltheus. Paleontol Res 10:91-96

Hammer Ø, Harper DAT, Ryan PD (2001) PAST: paleontological statistics software package for education and data analysis. Palaeontol Electron 4:A4

Hengsbach R (1976) Über die Sutur-Assymetrie bei Cymbites laevigatus (Ammonoidea; Jura). Senckenb Lethaea 56:463-468

Hengsbach R (1980) Über die Sutur-Asymmetrie bei Hecticoceras (Ammonoidea; Jura). Senckenb Lethaea 60:463-473

Hengsbach R (1986) Zur Kenntnis der Asymmetrie der Sutur-Asymmetrie bei Ammoniten. Senckenb Lethaea 67:119-149

Hewitt RA, Hurst JM (1977) Size changes in Jurassic liparoceratid ammonites and their stratigraphical and ecological significance. Lethaia 10:287-301

Hewitt RA, Stait B (1988) Seasonal variation in septal spacing of Sepia officinalis and some Ordovician actinocerid nautiloids. Lethaia 21:383-394

Hewitt RA, Checa A, Westermann GEG, Zaborski PM (1991) Chamber growth in ammonites inferred from colour markings and naturally etched surfaces of Cretaceous vascoceratids from Nigeria. Lethaia 24:271-287

Hewitt RA, Westermann GEG, Checa A (1993) Growth rates of ammonites estimated from aptychi. Geobios 26(Suppl 1):203-208

Hirano H (1978) Phenotypic substitution of Gaudryceras (a Cretaceous ammonite). Trans Proc Palaeontol Soc Jpn New Ser 109:235-258

Hirano H (1979) Importance of transient polymorphism in systematics of Ammonoidea. Gakujutsu Kenkyu Sch Educ Waseda Univ Ser Biol Geol 28:35-43

Hirano H (1981) Growth rates in Nautilus macromphalus and ammonoids: its implications. In: Martinell J (ed) International symposium on conceptions and methods in paleontology. University of Barcelona, Barcelona

Hoffmann R, Keupp H, Wiese F (2009) The systematic position of the Lower Cretaceous heteromorphic ammonite Pictetia Uhlig, 1883. Paläontol Z 83:521-531

Hohenegger J, Tatzreiter F (1992) Morphometric methods in determination of ammonite species, exemplified through Balatonites shells (Middle Triassic). J Paleontology 66:801-816

Hölder H (1956) Über Anomalien an jurassischen Ammoniten. Paläontol Z 30:95-107

Hoving H-JT, Gilly WF, Markaida U, Benoit-Bird KJ, Brown ZW, Daniel P, Field JC, Parassenti L, Liu B, Campos B (2013) Extreme plasticity in life-history strategy allows a migratory predator (jumbo squid) to cope with a changing climate. Glob Change Biol 19:2089-2103

Howarth MK (1973) The stratigraphy and ammonite fauna of the Upper Liassic grey shales of the Yorkshire coast. Bull Br Mus (Nat Hist) Geol 24:235-277

Howarth MK (1978) The stratigraphy and ammonite fauna of the Upper Lias of Northamptonshire. Bull Br Mus (Nat Hist) Geol 29:235-288

Hughes NC, Labandeira CC (1995) The stability of species in taxonomy. Paleobiology 21:401-403

Hunt G (2004a) Phenotypic variation in fossil samples: modeling the consequences of time-averaging. Paleobiology 30:426-443

Hunt G (2004b) Phenotypic variance inflation in fossil samples: an empirical assessment. Paleobiology 30:487-506

Hunt G (2006) Fitting and comparing models of phyletic evolution: random walks and beyond. Paleobiology 32:578-601

Hunt G (2007) Variation and early evolution. Science 317:459-460

Ikeda Y, Wani R (2012) Different modes of migration among late cretaceous ammonoids in northwestern Hokkaido, Japan: evidence from the analyses of shell whorls. J Paleontol 86:605-615

Ivanov AN (1971a) Problems of the periodization of ontogeny in ammonites. Yarosl Ped Inst Uch Zap geol i paleont 87:76-119 
Ivanov AN (1971b) On the problem of periodicity of the formation of septa in ammonoid shells and in that of other cephalopods. Yarosl Ped Inst Uch Zap geol i paleont 87:127-130

Ivanov AN (1975) Late ontogeny in ammonites and its characteristics in micro-, macro- and megaconchs. Yarosl Ped Inst Sb Nauchn Trudy 142:5-57

Jackson GD (1994) Application and future potential of statolith increment analysis in squids and sepioids. Can J Fish Aquat Sci 51:2612-2625

Jackson G, Moltschaniwskyj N (2002) Spatial and temporal variation in growth rates and maturity in the Indo-Pacific squid Sepioteuthis lessoniana (Cephalopoda: Loliginidae). Mar Biol 140:747-754

Jacobs DK (1990) Sutural pattern and shell stress in Baculites with implications for other cephalopod shell morphologies. Paleobiology 16:336-348

Jacobs DK, Landman NH, Chamberlain JA (1994) Ammonite shell shape co-varies with facies and hydrodynamics: iterative evolution as a response to changes in basinal environment. Geology 22:905-908

Jolliffe IT (2002) Principal component analysis. Springer, Netherlands

Joly B (2003) L'évolution chez les Phyllocerataceae, la variabilité des paramètres dimensionnels et relatifs. Variabilité de la complexité de la ligne cloisonnaire: Variabilité et paedomorphose. C R Pale 2:231-240

Joly B, Fonters B (2007) Morphotypes, polymorphism and peristome in the species of the genus Holcophylloceras Spath, 1927. Hypothesis of the dimorphism in the species Holcophylloceras zignodianum (d'Orbigny, 1848). Bull Soc Geol Fr 178:217-229

Jordan R, Stahl W (1971) Isotopische Paläotemperatur-Bestimmungen an Jurassischen Ammoniten und grundsätzliche Voraussetzungen für diese Methode. Geol Jahrb 89:33-62

Kakabadze MV (2004) Intraspecific and intrageneric variabilities and their implication for the systematics of Cretaceous heteromorph ammonites; a review. Scr Geol 128:17-37

Kampstra P (2008) Beanplot: a boxplot alternative for visual comparison of distributions. J Stat Softw 28, Code Snippet 1.

Kant R (1973a) Allometrisches Wachstum paläozoischer Ammonoideen: Variabilität und Korrelation einiger Merkmale. Neues Jahrb Geol Paläontol Abh 143:153-192

Kant R (1973b) Untersuchungen des allometrischen Gehäusewachstums paläozoischer Ammonoideen unter besonderer Berücksichtigung einzelner "Populationen.". N Jahrb Geol Paläont Abh 144:206-251

Kant R (1975) Biometrische Untersuchungen an Ammonoideen-Gehäusen. Paläontol Z 49:203220

Kaplan P (1999) Buckman's rule of covariation and other trends in Paleozoic Ammonoidea: morphological integration as key innovation. GSA 31:172

Kassab AS, Hamama HH (1991) Polymorphism in the upper Cretaceous ammonite Libycoceras ismaeli (Zittel). J Afr Earth Sci (Middle East) 12:437-448

Kawabe F (2003) Relationship between Mid-Cretaceous (upper Albian-Cenomanian) ammonoid facies and lithofacies in the Yezo forearc basin, Hokkaido, Japan. Cretac Res 24:751-763

Kenkel NC (2006) On selecting an appropriate multivariate analysis. Can J Plant Sci 86:663-676

Kennedy WJ (1972) The affinities of Idiohamites ellipticoides Spath (Cretaceous Ammonoidea). Palaeontology 15:400-404

Kennedy WJ (2013) On variation in Schloenbachia varians (J. Sowerby, 1817) from the lower Cenomanian of western Kazakhstan. Acta Geol Pol 63:443-446

Kennedy WJ, Cobban WA (1976) Aspects of ammonite biology, biogeography, and biostratigraphy. Spec Pap Palaeontol 17:1-94

Kennedy WJ, Hancock JM (1970) Ammonites of the genus Acanthoceras from the Cenomanian of Rouen, France. Palaeontology 13:462-490

Kennedy WJ, Wright CW (1985) Evolutionary patterns in Late Cretaceous ammonites. Spec Pap Palaeont 33:131-143

Kennedy WJ, Reyment RA, MacLeod N, Krieger J (2009) Species discrimination in the Lower Cretaceous (Albian) ammonite genus Knemiceras Von Buch 1848. Palaeontogr A 290:1-63

Keupp H (2000). Ammoniten: paläobiologische Erfolgsspiralen. Thorbecke, Stuttgart 
Keupp H (2012) Atlas zur Paläopathologie der Cephalopoden. Berl Palaeobiol Abh 12:1-392

Keupp H, Hoffmann R (2015) Ammonoid paleopathology. This volume

Keupp H, Mitta V (2013) Cephalopod jaws from the Middle Jurassic of Central Russia. Neues Jahrb Geol Paläontol Abh 270:23-54

Keyl F, Argüelles J, Tafur R (2011) Interannual variability in size structure, age, and growth of jumbo squid (Dosidicus gigas) assessed by modal progression analysis. ICES J Mar Sci J Cons 68:507-518

Kidwell SM (1998) Time-averaging in the marine fossil record: overview of strategies and uncertainties. Geobios 30:977-995

Kidwell SM (2002) Time-averaged molluscan death assemblages: palimpsests of richness, snapshots of abundance. Geology 30:803-806

Kidwell SM, Bosence DWJ (1991) Taphonomy and time-averaging of marine shelly faunas. In: Allison PA, Briggs DEG (eds) Taphonomy: releasing the data locked in the fossil record. Plenum, New York

Kin A (2010) Early Maastrichtian ammonites and nautiloids from Hrebenne, southeast Poland, and phenotypic plasticity of Acanthoscaphites tridens (Kner, 1848). Cretaceous Res 31:27-60

Kin A (2011) Phenotypic plasticity of Acanthoscaphites tridens (Late Cretaceous ammonites): additional data. Cretaceous Res 32:131-134

Klingenberg CP (1996) Multivariate allometry. In: Marcus LF et al (eds) Advances in morphometrics. Plenum, New York

Klinger HC, Kennedy WJ (1989) Cretaceous faunas from Zululand and Natal, South Africa. The ammonite family Placenticeratidae hyatt, 1900; with comments on the systematic position of the genus Hypengonoceras Spath, 1924. Ann S Afr Mus 98:241-408

Klug C, Riegraf W, Lehmann J (2012) Soft-part preservation in heteromorph ammonites from the Cenomanian-Turonian boundary event (OAE 2) in north-west Germany. Palaeontology 55:1307-1331

Klug C, Zatoń M, Parent H, Hostettler B, Tajika A (2015) Mature modifications and sexual dimorphism. This volume

Knauss MJ, Yacobucci MM (2014) Geographic information systems technology as a morphometric tool for quantifying morphological variation in an ammonoid clade. Palaeontol Electron $17: 19 \mathrm{~A}$

Korn D (1995) Impact of environmental perturbations on heterochronic development in Palaeozoic ammonoids. In: McNamara KJ (ed) Evolutionary change and heterochrony. Wiley, Chichester

Korn D, Klug C (2007) Conch form analysis, variability, morphological disparity, and mode of life of the Frasnian (Late Devonian) ammonoid Manticoceras from Coumiac (Montagne Noire, France). In: Landman NH, Davis RA, Mapes RH (eds) Cephalopods-present and past: new insights and fresh perspectives. Springer, Dordrecht

Korn D, Vöhringer E (2004) Allometric growth and intraspecific variability in the Basal Carboniferous ammonoid Gattendorfia crassa Schmidt, 1924. Paläontol Z 78:425-432

Kowalewski M (2009) The youngest fossil record and conservation biology: holocene shells as eco-environmental recorders. In: Dietl GP, Flessa KW (eds) Conservation paleobiology: using the past to manage for the future. Paleontological Society, New Haven

Kraft S, Korn D, Klug C (2008) Patterns of ontogenetic septal spacing in Carboniferous ammonoids. Neues Jahrb Geol Paläontol Abh 250:31-44

Kruta I, Landman NH, Tanabe K (2015) Ammonoid radulae. This volume

Krystyn L, Schäffer G, Schlager W (1971) Über die Fossil-Lagerstätten in den triadischen Hallstätter Kalken der Ostalpen. Neues Jahrb Geol Paläontol Abh 137:284-304

Kulicki C (1974) Remarks on the embryogeny and postembryonal development of ammonites. Acta Palaeontol Pol 19:201-224

Kummel B (1948) Environmental significance of dwarfed cephalopods. J Sediment Res 18:61-64

Landman NH (1987) Ontogeny of Upper Cretaceous (Turonian-Santonian) scaphitid ammonites from the western interior of North America: systematics, developmental patterns, and life history. Bull Am Mus Nat Hist 185:117-241 
Landman NH, Geyssant JR (1993) Heterochrony and ecology in Jurassic and Cretaceous ammonites. Geobios 26(Suppl 1):247-255

Landman NH, Waage KM (1986) Shell abnormalities in scaphitid ammonites. Lethaia 19:211-224

Landman NH, Waage KM (1993) Scaphitid ammonites of the Upper Cretaceous (Maastrichtian) Fox Hills formation in South Dakota and Wyoming. Bull Am Mus Nat Hist 215:1-257

Landman N, Klofak SM, Sarg KB (2008) Variation in adult size of scaphitid ammonites from the Upper Cretaceous Pierre Shale and Fox Hills formation. In: Harries PJ (ed) High-resolution approaches in stratigraphic paleontology. Springer, Netherlands

Landman NH, Kennedy WJ, Cobban WA, Larson NL (2010) Scaphites of the "Nodosus Group" from the Upper Cretaceous (Campanian) of the Western Interior of North America. Bull Am Mus Nat Hist 342:1-242

Landman NH, Cobban WA, Larson NL (2012) Mode of life and habitat of scaphitid ammonites. Geobios 45:87-98

Lange W (1929) Zur Kenntnis des Oberdevons am Enkeberg und bei Balve (Sauerland). Abh Preuss Geol Landesanst NF 119:1-132

Lange W (1941) Die Ammonitenfauna der Psiloceras-Stufe Norddeutschlands. Palaeontogr A 93:1-186

Laptikhovsky V (2006) Latitudinal and bathymetric trends in egg size variation: a new look at Thorson's and Rass's rules. Mar Ecol 27:7-14

Laptikhovsky VL, Rogov MA, Nikolaeva SE, Arkhipkin AI (2013) Environmental impact on ectocochleate cephalopod reproductive strategies and the evolutionary significance of cephalopod egg size. Bull Geosci 88:83-94

Lawrence E (2000) Henderson's dictionary of biological terms. Pearson, Essex

Lécuyer C, Bucher H (2006) Stable isotope compositions of a late Jurassic ammonite shell: a record of seasonal surface water temperatures in the southern hemisphere? eEarth 1:1-7

Lehmann U (1981) The ammonites: their life and their world. Cambridge University, New York

Lehmann U (1990) Ammonoideen. Enke, Stuttgart

Leporati S, Pecl G, Semmens J (2007) Cephalopod hatchling growth: the effects of initial size and seasonal temperatures. Mar Biol 151:1375-1383

Levene H (1960) Robust test for the equality of variances. In: Olkin I, Ghurye SG, Hoeffding W, Madow WG, Mann HB (eds) Contributions to probability and statistics: essays in honor of harold hotelling. Stanford University, Stanford

Levins R (1968) Evolution in changing environments. Princeton University, Princeton, p 120

Machalski M (2010) Early Maastrichtian ammonites and nautiloids from Hrebenne, southeast Poland, and phenotypic plasticity of Acanthoscaphites tridens (Kner, 1848): a commentary. Cretaceous Res 31:593-595

Makowski H (1962) Problem of sexual dimorphism in ammonites. Palaeontol Pol 12:1-92

Makowski H (1991) Dimorphism and evolution of the goniatite Tornoceras in the Famennian of the holy cross mountains. Acta Palaeontol Pol 36:241-254

Mancini EA (1978) Origin of micromorph faunas in the geologic record. J Paleontol 52:311-322

Manger WL, Meeks LK, Stephen DA (1999) Pathologic gigantism in middle Carboniferous cephalopods, southern midcontinent, United States. In: Olóriz F, Rodríguez-Tovar FJ (eds) Advancing research on living and fossil cephalopods. Kluwer Academic/Plenum, New York

Mangold K (1983) Food, feeding and growth in cephalopods. Mem Natl Mus Vic 44:81-93

Manship LL (2004) Pattern matching: classification of ammonitic sutures using GIS. Palaeontol Electron 7(6A):1-15

Manship LL (2008) Variation analysis of ammonites and conodonts (implementing Geographic Information Systems): a qualitative and quantitative method. Texas Tech University, Lubbock

Mapes RH, Larson NL (2015) Colour patterns. This volume

Mapes RH, Sneck DA (1987) The oldest 'colour' patterns: description, comparison with Nautilus, and implications. Palaeontology 30:299-309

Marchand D (1976) Quelques précisions sur le polymorphisme dans la famille des Cardioceratidae Douville (Ammonoidea). Haliotis 6:119-140 
Matsunaga T, Maeda H, Shigeta Y, Hasegawa K, Nomura S-I, Nishimura T, Misaki A, Tanaka G (2008) First discovery of Pravitoceras sigmoidale Yabe from the Yezo supergroup in Hokkaido, Japan. Paleontol Res 12:309-319

Matyja BA (1986) Developmental polymorphism in Oxfordian ammonites. Acta Geol Pol 36:3767

Matyja BA (1994) Developmental polymorphism in the Oxfordian ammonite subfamily Peltoceratinae. Palaeopelagos Spec Publ 1:277-286

Matyja BA, Wierzbowski A (2000) Biological response of ammonites to changing environmental conditions: an example of Boreal Amoeboceras invasions into Submediterranean province during Late Oxfordian. Acta Geol Pol 50:45-54

Mayr E (1963) Animal species and evolution. Belknap of Harvard University , Cambridge

McCaleb JA (1968) Lower Pennsylvanian ammonoids from the Bloyd formation of Arkansas and Oklahoma. GSA Special Papers 96:1-118

McCaleb JA, Furnish WM (1964) The Lower Pennsylvanian ammonoid genus Axinolobus in the southern Midcontinent. J Paleontol 38:249-255

McCaleb JA, Quinn JH, Furnish WM (1964) Girtyoceratidae in the southern Midcontinent. Okla Geol Surv Circ 67:1-41

Meischner D (1968) Perniciöse Epökie von Placunopsis auf Ceratites. Lethaia 1:156-174

Meister C (1989) Les ammonites du Crétacé supérieur d'Ashaka (Nigéria). Bull Centres Rech Explor-Prod Elf-Aquitaine 13(Suppl):1-84

Meléndez G, Fontana B (1993) Intraspecific variability, sexual dimorphism, and non-sexual polymorphism in the ammonite genus Larcheria Tintant (Perisphinctidae) from the middle Oxfordian of western Europe. In: House MR (ed) The Ammonoidea: environment, ecology, and evolutionary change. Clarendon, Oxford

Merkt J (1966) Über Austern und Serpeln als Epöken auf Ammonitengehäusen. Neues Jahrb Geol Paläontol Abh 125:467-479

Michalsky AO (1890) Ammonites of the Lower Volgian stage. Tr Geol kom-ta St. Petersburg 8:361-369 [in Russian]

Mignot Y (1993) Un problème de paléobiologie chez les ammonoides (Cephalopoda): croissance et miniaturisation en liaison avec les environnements. Doc Lab Geol Lyon 124:1-113

Mignot Y, Elmi S, Dommergues J-L (1993) Croissance et miniaturisation de quelques Hildoceras (Cephalopoda) en liaison avec des environnements contraignants de la Téthys Toarcienne. Geobios 26(Suppl 1):305-312

Miller RG (1974) The jackknife-a review. Biometrika 61:1-15

Mitta VV (1990) Intraspecific variability in the Volgian ammonites. Paleontol J 1990:10-15

Monnet C, Bucher H (2005) New middle and late Anisian (Middle Triassic) ammonoid faunas from northwestern Nevada (USA): taxonomy and biochronology. Fossils Strata 52:1-121

Monnet C, Brack P, Bucher H, Rieber H (2008) Ammonoids of the middle/late Anisian boundary (Middle Triassic) and the transgression of the prezzo limestone in eastern Lombardy-Giudicarie (Italy). Swiss J Geosci 101:61-84

Monnet C, Bucher H, Wasmer M, Guex J (2010) Revision of the genus Acrochordiceras Hyatt, 1877 (Ammonoidea, Middle Triassic): morphology, biometry, biostratigraphy and intraspecific variability. Palaeontology 53:961-996

Monnet C, De Baets K, Klug C (2011a) Parallel evolution controlled by adaptation and covariation in ammonoid cephalopods. BMC Evol Biol 11:115

Monnet C, Klug C, Goudemand N, De Baets K, Bucher H (2011b) Quantitative biochronology of Devonian ammonoids from Morocco and proposals for a refined unitary association method. Lethaia 44:469-489

Monnet C, Bucher H, Guex J, Wasmer M (2012) Large-scale evolutionary trends of Acrochordiceratidae Arthaber, 1911 (Ammonoidea, Middle Triassic) and Cope's rule. Palaeontology 55:87-107

Monnet C, De Baets K, Yacobucci MM (2015a) Buckman's rules of covariation. In: Klug C, Korn D, De Baets K, Kruta I, Mapes RH (eds) Ammonoid paleobiology: from macroevolution to paleogeography. Springer, Dordrecht 
Monnet C, Klug C, De Baets K (2015b) Evolutionary patterns of ammonoids: phenotypic trends, convergence, and parallel evolution. In: Klug C, Korn D, De Baets K, Kruta I, Mapes RH (eds) Ammonoid paleobiology: from macroevolution to paleogeography. Springer, Dordrecht

Morard A (2004) Les événements du passage Domérien-Toarcien entre Thétys occidentale et Europe du Nord-Ouest. 1-338. Thèse de Doctorat, Université de Lausanne, Lausanne

Morard A (2006) Covariation patterns in ammonoids: observations, models, and open questions. Proceedings of the 4th Swiss Geoscience Meeting, Bern

Morard A, Guex J (2003) Ontogeny and covariation in the Toarcian genus Osperleioceras (Ammonoidea). Bull Soc Geol Fr 174:607-615

Naglik C, Tajika A, Chamberlain JA, Klug C (2015) Ammonoid locomotion. This volume

Nardin E, Rouget I, Neige P (2005) Tendencies in paleontological practice when defining species, and consequences on biodiversity studies. Geology 33:969-972. doi:10.1130/g21838.1

Neige P (1997) Ontogeny of the Oxfordian ammonite Creniceras renggeri from the Jura of France. Eclogae Geol Helv 90:605-616

Neige P, Dommergues J-L (1995) Morphometric and phenetics versus cladistic analysis of the early Harpoceratinae (Pliensbachian ammonites). Neues Jahrb Geol Paläontol Abh 196:411-438

Neige P, Marchand D, Laurin B (1997a) Heterochronic differentiation of sexual dimorphs among Jurassic ammonite species. Lethaia 30:145-155

Neige P, Chaline J, Chone T, Courant F, David B, Dommergues J-L, Laurin B, Madon C, MagniezJannin F, Marchand D, Thierry J (1997b) La notion d'espace morphologique, outil d'analyse de la morphodiversité des organismes. Geobios 30(Suppl 1):415-422

Nigmatullin CM, Nesis KN, Arkhipkin AI (2001) A review of the biology of the jumbo squid Dosidicus gigas (Cephalopoda: Ommastrephidae). Fish Res 54:9-19

Oechsle E (1958) Stratigraphie und Ammonitenfauna der Sonninien-Schichten des Filsgebiets unter besonderer Berucksichtgung der Sowerbyi Zone (Mittlerer Doggers, Wuttemberg). Palaeontogr A 111:47-129

Olóriz F (2000) Time-averaging and long-term palaeoecology in macroinvertebrate fossil assemblages with ammonites (Upper Jurassic). Rev Paleobiol 19:123-140

Olóriz F, Palmqvist P, Pérez-Claros JA (1997) Shell features, main colonized environments, and fractal analysis of sutures in Late Jurassic ammonites. Lethaia 30:191-204

Oloriz F, Palmqvist P, Perez-Claros JA (1999) Recent advances in morphometric approaches to covariation of shell features and the complexity of suture lines in Late Jurassic ammonites, with reference to the major environments colonized. In: Oloriz F, Rodriguez-Tovar FJ (eds) Advancing research on living and fossil cephalopods. Kluwer Academic/Plenum, New York

Olóriz F, Villaseñor AB, González-Arreola C (2000) Geographic control on phenotype expression. The case of Hybonoticeras mundulum (Oppel) from the Mexican Altiplano. Lethaia 33:157174

Palframan DFB (1966) Variation and ontogeny of some Oxfordian ammonites: Taramelliceras richei (de Loriol) and Creniceras renggeri (Oppel), from Woodham, Buckinghamshire. Palaeontology 9:290-311

Palframan DFB (1967) Variation and ontogeny of some oxford clay ammonites: Distichoceras bicostatum (Stahl) and Horioceras baugieri (D’Orbigny), from England. Palaeontology 10:60 94

Parent H (1998) Upper Bathonian and lower Callovian ammonites from Chacay Melehué (Argentina). Acta Palaeontol Pol 43:69-130

Parent H, Scherzinger A, Schweigert G (2008) Sexual phenomena in late Jurassic Aspidoceratidae (Ammonoidea). Dimorphic correspondence between Physodoceras hermanni (Berckhemer) and Sutneria subeumela Schneid, and first record of possible hermaphroditism. Palaeodiversity $1: 181-187$

Parent H, Greco AF, Bejas M (2009) Size-shape relationships in the Mesozoic planispiral ammonites. Acta Palaeontol Pol 55:85-98

Parent H, Bejas M, Greco A, Hammer O (2011) Relationships between dimensionless models of ammonoid shell morphology. Acta Palaeontol Pol 57:445-447 
Paul CRC (2011) Sutural variation in the ammonites Oxynoticeras and Cheltonia from the Lower Jurassic of Bishop's Cleeve, Gloucestershire, England and its significance for ammonite growth. Palaeogeogr. Palaeoclimatol Palaeoecol 309:201-214

Pavia G (2006) Nomenclatural suitability in ammonoid classification: generic versus subgeneric status of dimorphic pairs. Volumina Jurassica 7:254

Pearson K (1895) Contributions to the mathematical theory of evolution II. Skew variation in homogeneous material. Philos Trans Roy Soc Lond A 186:343-414

Pearson K (1901) On lines and planes of closest fit to systems of points in space. Philos Phenomenol 2:559-572

Pecl G, Jackson G (2008) The potential impacts of climate change on inshore squid: biology, ecology and fisheries. Rev Fish Biol Fish 18:373-385

Pecl GT, Steer MA, Hodgson KE (2004) The role of hatchling size in generating the intrinsic size-at-age variability of cephalopods: extending the Forsythe hypothesis. Mar Freshw Res 55:387-394

Pfaff E (1911) Über Form und Bau der Ammonitensepten und ihre Beziehungen zur Suturlinie. Jb Niedersächs Geol 4:208-223

Pictet FJ (1854) Traité de paléontologie, Céphalopodes, 2. B. Baillière, Paris

Ploch I (2003) Taxonomic interpretation and sexual dimorphism in the Early Cretaceous (Valanginian) ammonite Valanginites nucleus (ROEMER, 1841). Acta Geol Pol 53:201-208

Ploch I (2007) Intraspecific variability and problematic dimorphism in the Early Cretaceous (Valanginian) ammonite Saynoceras verrucosum (d'Orbigny, 1841). Acta Geol Sin 81:877-882

Powell EN, Davies DJ (1990) When Is an "Old" shell really old? J Geol 98:823-844

Rawson PF (1975a) The interpretation of the Lower Cretaceous heteromorph ammonite genera Paracrioceras and Hoplocrioceras Spath, 1924. Palaeontology 18:275-283

Rawson PF (1975b) Lower Cretcaeous ammonites from north-east England: the Hauterivian heteromorph Aegocrioceras. Bull Br Mus (Nat Hist) Geol 26:139-159

Reboulet S (2001) Limiting factors on shell growth, mode of life and segregation of Valanginian ammonoid populations: evidence from adult-size variations. Geobios 34:423-435

Reeside JB, Cobban WA (1960) Studies of the Mowry shale (Cretaceous) and contemporary formations in the United States and Canada. US Geol Surv Prof Pap 355:1-126

Reyment RA (1988) Does sexual dimorphism occur in cretaceous ammonoids? Senckenb Lethaea 69:109-119

Reyment RA (2003) Morphometric analysis of variability in the shell of some Nigerian Turonian (Cretaceous) ammonites. Cretaceous Res 24:789-803

Reyment R (2004) Instability in principal component analysis and the quantification of polyphenism in palaeontological data. Math Geol 36:629-638

Reyment RA (2011) Morphometric analysis of polyphenism in Lower Cretaceous ammonite genus Knemiceras. In: Elewa AMT (ed) Computational paleontology. Springer, Berlin

Reyment RA, Kennedy WJ (1991) Phenotypic plasticity in a cretaceous ammonite analyzed by multivariate statistical methods. Methodol Study Evol Biol 25:411-426

Reyment RA, Kennedy WJ (1998) Taxonomic recognition of species of Neogastroplites (Ammonoidea, Cenomanian) by geometric morphometric methods. Cretaceous Res 19:25-42

Reyment RA, Kennedy WJ (2000) Morphological links in an evolutionary sequence of the cretaceous ammonite genus Metoicoceras Hyatt. Cretaceous Res 21:845-849

Reyment RA, Minaka N (2000) A note on reiterated phenotypes in species of Neogastroplites (Ammonoidea, Cenomanian, Cretaceous). Cretaceous Res 21:173-175

Rieber H (1973) Ergebnisse paläontologisch-stratigraphischer Untersuchungen in der Grenzbitumenzone (Mittlere Trias) des Monte San Giorgio (Kanton Tessin, Schweiz). Eclog Geol Helv 66:667-685

Ritterbush KA, Hoffmann R, Lukeneder A, De Baets K (2014) Pelagic palaeoecology: the importance of recent constraints on ammonoid palaeobiology and life history. J Zool 292:229-241

Rocha R, Dias R (2005) Finite strain analysis using ammonoids: an interactive approach. J Struct Geol 27:475-479 
Ropolo P (1995) Implications of variation in coiling in some Hauterivian (Lower Cretaceous) heteromorph ammonites from the Vocontian basin, France. Mem Descr Cart Geol Ital 51:137-165

Rouget I, Neige P (2001) Embryonic ammonoid shell features: intraspecific variation revisited. Palaeontology 44:53-64

Salgado-Ugarte IH, Shimizu M, Taniuchi T, Matsushita K (2000) Size frequency analysis by averaged shifted histograms and kernel density estimators. Asian Fish Sci 13:1-12

Sandoval J, Chandler RB (2000) The sonniniid ammonite Euhoploceras from the Middle Jurassic of south-west England and southern Spain. Palaeontology 43:495-532

Sanvicente-Añorve L, Salgado-Ugarte I, Castillo-Rivera M (2003) The use of kernel density estimators to analyse length-frequency distributions of fish larvae. In: Browman HI, Skiftesvik $\mathrm{AB}$ (eds) The big fish bang. Proceedings of the 26th annual larval fish conference. Institute of Marine Research, Bergen

Sarti C (1999) Whorl width in the body chamber of the ammonites as a sign of dimorphism. In: Olóriz F, Rodríguez-Tovar F(eds) Advancing research on living and fossil cephalopods. Kluwer Academic, Plenum, New York

Saunders WB, Swan ARH (1984) Morphology and morphologic diversity of Mid-Carboniferous (Namurian) ammonoids in time and space. Paleobiology 10:195-228

Schindewolf OH (1934) Über Epöken auf Cephalopoden-Gehäusen. Paläontol Z 16:15-31

Schindewolf OH (1961) Die Ammoniten-Gattung Cymbites im deutschen Lias. alaeontogr Abt A Palaeozool-Stratigr 117:193-232

Schmidt H (1926) Neotenie und beschleunigte Entwicklung bei Ammoneen. Paläontol Z 7:197205

Schweigert G, Dietze V, Chandler RB, Mitta VV (2007) Revision of the Middle Jurassic dimorphic ammonite genera Strigoceras/Cadomoceras (Strigoceratidae) and related forms. Stuttg Beitr Nat Ser B (Geol Paläont) 373:1-74

Seilacher A (1973) Fabricational noise in adaptive morphology. Syst Zool 22:451-465

Seilacher A (1988) Why are nautiloid and ammonite sutures so different? Neues Jahrb Geol Paläontol Abh 177:41-69

Silberling NJ (1956) "Trachyceras Zone" in the Upper Triassic of the western United States. J Paleontol 30:1147-1153

Silberling NJ, Nichols KM (1982) Middle Triassic molluscan fossils of biostratigraphic significance from the Humboldt Range, northwestern Nevada. U.S. Geological Survey Professional Paper 1207:1-77

Simpson GG (1944) Tempo and mode in evolution. Columbia University Press, New York, p. 237

Simpson Stephen J, Sword Gregory A, Lo N (2011) Polyphenism in insects. Curr Biol 21:R738 R749

Spath LF (1919) V.-Notes on Ammonites: I. Geol Mag 6:27-35

Spearman C (1904) The proof and measurement of association between two things. Am J Psychol 15:72-10

Sprent P (1989) Applied nonparametric statistical methods. Chapman \& Hall, London

Stephen DA, Stanton RJ (2002) Impact of reproductive strategy on cephalopod evolution. Abh Geol Bundesanst 57:151-155

Stephen DA, Manger WL, Baker C (2002) Ontogeny and heterochrony in the middle Carboniferous ammonoid Arkanites relictus (Quinn, McCaleb, and Webb) from northern Arkansas. J Paleontol 76:810-821

Stevens GR (1988) Giant ammonites: a review. In: Wiedmann J, Kullmann J (eds) Cephalopodspresent and past. Schweizerbart, Stuttgart

Sturani C (1971) Ammonites and stratigraphy of the "Posidonia Alpina" beds of the Venetian Alps (Middle Jurassic, Mainly Bajocian). Mem Ist Geol Mineral Univ Padova 28:1-190

Swan ARH, Saunders WB (1987) Function and shape in late Paleozoic (Mid-Carboniferous) ammonoids. Paleobiology 13:297-311

Tajika A, Wani R (2011) Intraspecific variation of hatchling size in late Cretaceous ammonoids from Hokkaido, Japan: implication for planktic duration at early ontogenetic stage. Lethaia 44:287-298 
Tan BK (1973) Determination of strain ellipses from deformed ammonoids. Tectonophys 16:89101

Tanabe K (1977a) Mid-Cretaceous scaphitid ammonites from Hokkaido. Palaeontological Society of Japan. Special Papers 21:11-22

Tanabe K (1977b) Functional evolution of Otoscaphites puerculus (Jimbo) and Scaphites planus (Yabe), Upper Cretaceous ammonites, Series D (Geology) 23. Memoirs of the Faculty of Science, Kyushu University, pp 367-407

Tanabe K (1993) Variability and mode of evolution of the Middle Cretaceous ammonite Subprionocyclus (Ammonitina: Collignoniceratidae) from Japan. Geobios 26(Suppl 1):347-357

Tanabe K, Shigeta Y (1987) Ontogenetic shell variation and streamlining of some Cretaceous ammonites. Transactions and Proceedings of the Palaeontological Society of Japan, New Series 147:165-179

Tanabe K, Shigeta Y, Mapes RH (1995) Early life history of Carboniferous ammonoids inferred from analysis of shell hydrostatics and fossil assemblages. Palaios 10:80-86

Tanabe K, Landman NH, Yoshioka Y (2003) Intra- and interspecific variation in the early internal shell features of some Cretaceous ammonoids. J Paleontol 77:876-887

Thierry J (1978) Le genre Macrocephalites au Callovien Inférieur (Ammonites, Jurassique Moyen). Mémoires Géologiques de l’Université de Dijon 4:1-490Tintant H (1963) Les kosmocératidés du Callovien inférieur et moyen d'Europe occidentale: essai de paléontologie quantitative. 29. Presses universitaires de France. Publications de l'Université de Dijon 29:1-491

Tintant H (1963) Les kosmocératidés du Callovien inférieur et moyen d'Europe occidentale: essai de paléontologie quantitative, vol 29. Publications de l'Universite de Dijon, Paris, pp. 1-491

Tintant H (1976) Le polymorphisme intraspécifique en paléontologie. Haliotis 6:49-69

Tintant H (1980) Problématique de l'espèce en Paléozoologie. Mem Soc Zool Fr 40:321-372

Tozer ET (1971) Triassic time and ammonoids: problems and proposals. Canad J Earth Sci 8:9891031

Trueman AE (1940) The ammonite body-chamber, with special reference to the buoyancy and mode of life of the living ammonite. Q J Geol Soc 96:339-383

Tsujino Y, Naruse H, Maeda H (2003) Estimation of allometric shell growth by fragmentary specimens of Baculites tanakae Matsumoto and Obata (a Late Cretaceous heteromorph ammonoid). Paleontol Res 7:245-255

Ubukata T, Tanabe K, Shigeta Y, Maeda H, Mapes RH (2008) Piggyback whorls: a new theoretical morphologic model reveals constructional linkages among morphological characters in ammonoids. Acta Palaeontol Pol 53:113-128

Urdy S (2015) Theoretical modelling of the molluscan shell: what has been learned from the comparison among molluscan taxa? This volume

Urdy S, Goudemand N, Bucher H, Chirat R (2010a) Allometries and the morphogenesis of the molluscan shell: a quantitative and theoretical model. J Exp Zool B 314:280-302

Urdy S, Goudemand N, Bucher H, Chirat R (2010b) Growth dependent phenotypic variation of molluscan shell shape: implications for allometric data interpretation. J Exp Zool B 314:303326

Urdy S, Wilson LAB, Haug JT, Sánchez-Villagra MR (2013) On the unique perspective of paleontology in the study of developmental evolution and biases. Biol Theory 8:1-19. doi:10.1007/ s13752-013-0115-1

Urlichs M (2004) Kümmerwuchs bei Lobites Mosjsisovics, 1902 (Ammonoidea) aus dem UnterKarnium der Dolomiten (Ober-Trias, Italien) mit Revision der unterkarnischen Arten. Stuttg Beitr Nat Ser B (Geol Palaont) 344:1-37

Urlichs M (2012) Stunting in some invertebrates from the Cassian formation (Late Triassic, Carnian) of the Dolomites (Italy). Neues Jahrb Geol Paläontol Abh 265:1-25

Van Valen L (1978) The statistics of variation. Evolut Theory 4:33-43

Van Valen L (2005) The statistics of variation. In: Hallgrímsson B, Hall BK (eds) Variation: a central concept in biology. Academic, Burlington

Vermeulen J (2002) Étude stratigraphique et paléontologique de la famille des Pulchelliidae (Ammonoidea, Ammonitina, Endemocerataceae). Geol Alp Hors Ser 42:331-333 
Vogel K-P (1959) Zwergwuchs bei Polyptychiten (Ammonoidea). Geol Jahrb 76:469-540

Waggoner KJ (2006) Sutural form and shell morphology of Placenticeras and systematic descriptions of late cretaceous ammonites from the big bend region, Texas. 1-398. Texas Tech University, Lubbock

Wagner FH (2000) Intraspecific variation. McGraw-Hill Yearbook of Science and Technology

Wagner GP, Altenberg L (1996) Perspective: complex adaptations and the evolution of evolvability. Evolution Int J org Evolution 50:967-976

Wani R (2001) Reworked ammonoids and their taphonomic implications in the upper cretaceous of northwestern Hokkaido, Japan. Cretaceous Res 22:615-625

Wani R, Gupta NS (2015) Ammonoid taphonomy. In: Klug C, Korn D, De Baets K, Kruta I, Mapes RH (eds) Ammonoid paleobiology: from macroevolution to paleogeography. Springer, Dordrecht

Ward P (1980) Comparative shell shape distributions in Jurassic-Cretaceous ammonites and Jurassic-Tertiary nautilids. Paleobiology 6:32-43

Ward PD (1987) The natural history of Nautilus. Allen \& Unwin, Boston

Ward PD, Westerman GEG (1985) Cephalopod paleoecology. In: Broadhead TW (ed) Mollusks, notes for a short cource. University of Tennessee, Knoxville

Weitschat W (2008) Intraspecific variation of Svalbardiceras spitzbergensis (Frebold) from the early Triassic (Spathian) of Spitsbergen. Polar Res 27(3):292-297

Weitschat W, Bandel K (1991) Organic components in phragmocones of Boreal Triassic ammonoids: implications for ammonoid biology. Paläontol Z 65:269-303

Wendt J (1971) Genese und Fauna submariner sedimentärer Spaltenfüllungen im mediterranen Jura. Palaeontogr A 136:121-192

West-Eberhard MJ (1989) Phenotypic plasticity and the origins of diversity. Annu Rev Ecol Syst 20:249-278

West-Eberhard MJ (2003) Developmental plasticity and evolution. Oxford University, Oxford

West-Eberhard MJ (2005) Developmental plasticity and the origin of species differences. Proc Natl Acad Sci USA 102:6543-6549

Westermann G (1964) Sexual-Dimorphismus bei Ammonoideen und seine Bedeutung für die Taxonomie der Otoitidae (einschließlich Sphaeroceratinae; Ammonitina, M. Jura). Palaeontogr A:33-73

Westermann GEG (1966) Covariation and taxonomy of the Jurassic ammonite Sonninia adicra (Waagen). Neues Jahrb Geol Paläontol Abh 124:289-312

Westermann GEG (1971) Form, structure and function of shell and siphuncle in coiled Mesozoic ammonoids. Life Sci Contrib, Royal Ontario Museum 78:1-39

Westermann GEG (1996) Ammonoid life and habitat. In: Landman NH, Tanabe K, Davis RA(eds) Ammonoid paleobiology. Plenum, New York

Westermann GEG, Callomon J (1988) The Macrocephalitinae and associated Bathonian and early Callovian (Jurassic) ammonoids of the Sula Islands and New Guinea. Palaeontogr A 203:1-90

Wiedmann J (1969) The heteromorphs and ammonoid extinction. Biol Rev 44:563-602

Wiedmann J, Dieni I (1968) Die Kreide Sardiniens und ihre Cephalopoden. Palaeontogr Italica 64:1-171

Wiese F, Schulze F (2005) The Upper Cenomanian (Cretaceous) ammonite Neolobites vibrayeanus (d'Orbigny, 1841) in the Middle East: taxonomic and palaeoecologic remarks. Cretaceous Res 26:930-946

Willmore KE, Young NM, Richtsmeier JT (2007) Phenotypic variability: its components, measurement and underlying developmental processes. Revolut Biol 34(3-4):99-120

Wilmsen M, Mosavinia A (2011) Phenotypic plasticity and taxonomy of Schloenbachia varians (J. Sowerby, 1817) (Cretaceous Ammonoidea). Paläontol Z 85:169-184

Yacobucci MM (2004a) Buckman's paradox: variability and constraints on ammonoid ornament and shell shape. Lethaia 37:57-69

Yacobucci MM (2004) Neogastroplites meets Metengonoceras: morphological response of an endemic hoplitid ammonite to a new invader in the mid-cretaceous mowry sea of North America. Cretaceous Res 25:927-944 
Yacobucci MM (2008) Controls on shell shape in acanthoceratid ammonites from the Cenomanian-Turonian Western Interior seaway. In: Harries PJ (ed) High-resolution approaches in stratigraphic paleontology. Springer, Netherlands

Yacobucci MM, Manship LL (2011) Ammonoid septal formation and suture asymmetry explored with a geographic information systems approach. Palaeontol Electron 14:3A:17

Yahada H, Wani R (2013) Limited migration of scaphitid ammonoids: evidence from the analyses of shell whorls. J Paleontol 87:406-412

Yamaji A, Maeda H (2013) Determination of 2D strain from a fragmented single ammonoid. Isl Arc 22:126-132

Zakharov YD (1977) Ontogeny of ceratites of the genus Pinacoceras and developmental features of the suborder Pinacoceratina. Paleontol J 4:445-445

Zatoń M (2008) Taxonomy and palaeobiology of the Bathonian (Middle Jurassic) tulitid ammonite Morrisiceras. Geobios 41:699-717.

Zittel KA von (1885) Handbuch der Paläontologie, Abt. 1, Bd. 2. R. Oldenbourg, München

Zuev GV (1971) Cephalopods from the north-western part of the Indian Ocean. Naukova Dumka, Kiev in Russian

Zuev GV (1976) Physiological variability of the females of the squid Symplectoteuthis pteropus (Steenstrup). Biol Sea 38:55-62 [in Russian] 